\title{
Bibliografia historii wychowania, szkolnictwa i myśli pedagogicznej w Polsce za rok 2013 (z zupelnieniami za lata poprzednie)
}

DOI: $10.14746 /$ BHW.2014.31.18

\begin{abstract}
Wstęp
Bibliografia rejestruje druki zwarte, artykuły z czasopism i prac zbiorowych, wydane w 2013 roku oraz w latach wcześniejszych, które nie zostały ujęte w poprzednich częściach bibliografii, publikowanych na łamach Biuletynu Historii Wychowania od 2002 r. Nie uwzględniono recenzji, które ukazały się w 2013 r., ale dotyczyły publikacji zarejestrowanych we wcześniejszych częściach bibliografii. Bibliografia ma układ według podanego niżej schematu. W poszczególnych działach i poddziałach (z wyjątkiem poddziału 5. Szkoły wyższe w Dziale III, gdzie zastosowano układ według nazw szkół oraz poddziału 2. Poszczególne biografie w Dziale IV, w którym pozycje ułożone zostały według nazwisk osób) zastosowano układ alfabetyczny według haseł autorskich lub tytułowych. Opisy w razie potrzeby zostały uzupełnione adnotacjami, a w przypadku prac zbiorowych wyszczególniono składające się na nie artykuły, dotyczące historii oświaty i wychowania.
\end{abstract}

Schemat układu bibliografii:

I. Opracowania ogólne. Bibliografie

II. Rozwój oświaty, wychowania i myśli pedagogicznej

1. Opracowania ogólne

2. Okres do 1795 roku

3. Okres $1795-1918$

4. Okres 1918-1939

5. Okres 1939-1945

6. Okres 1945-1989

7. Okres 1989-2013

8. Oświata polonijna

III. Dzieje szkół różnych stopni

1. Szkoły podstawowe i zakłady wychowawcze

2. Szkoły ponadpodstawowe ogólnokształcące

3. Szkoły zawodowe

4. Zakłady kształcenia nauczycieli (z wyjątkiem szkół wyższych)

5. Szkoły wyższe

IV. Biografie

1. Zbiory życiorysów

2. Poszczególne biografie

V. Dzieje oświaty pozaszkolnej

1. Oświata dorosłych 
2. Biblioteki

VI. Dzieje ruchu nauczycielskiego

1. Opracowania ogólne

2. Pamiętniki nauczycieli

VII. Organizacje młodzieżowe

1. Harcerstwo

2. Inne 


\section{OPRACOWANIA OGÓLE. BIBLIOGRAFIE}

1. BIBLIOGRAFIA historii wychowania, szkolnictwa i myśli pedagogicznej w Polsce za rok 2010 (z uzupełnieniami za lata poprzednie). Oprac. Anna Gruca. Biuletyn Historii Wychowania. [Nr] 29: 2013 s. 193-265.

2. BRZUSKA-KĘPA Alina: „Dziecko w świecie książki i mediów” - sprawozdanie z konferencji. Acta Universitatis Lodziensis. Folia Librorum. [Vol.] 17: 2013 s. 261-266.

Łódź, 10-11 V 2012 r.

3. DORMUS Katarzyna: Rola czasopism historyczno-oświatowych w kształtowaniu się historii wychowania jako samodzielnej dyscypliny naukowej. Rozprawy z Dziejów Oświaty. T. 50: 2013 s. $27-50$, sum.

4. HOSZOWSKA Mariola: Ludwik Finkel a lwowskie środowisko historyków oświaty i wychowania. [W:] Badacze przeszłości wobec wyzwań XIX-XXI wieku. Red. Katarzyna Błachowska, Zbigniew Romek, Marcin Wolniewicz. Warszawa 2013 s. 195-211.

5. JANUSZ Korczak, Piotr Skarga - wielcy reformatorzy, społecznicy i wychowawcy wyzwaniem dla współczesnych pedagogów. Red. nauk. Maria Żak, Ewa Tłuczek-Tadla, Malwina Cichowska. Jarosław 2013 Wydaw. Państ. Wyższej Szkoły Techn.-Ekonom. ss.

149, nlb. 2, il., sum. (Dyskurs Pedagogiczny; t. 8, R. 2013).

Z treści: Chodakowska Maria: Indywidualne czynniki zmiany społeczno-edukacyjnej na przykładzie aktywności pedagogicznej Janusza Korczaka s. 13-27; Podbilska-Kłosowska Agnieszka: Janusz Korczak - wzór wartości humanistycznych s. 29-38; Dyndał Stanisław: Życie i działalność Janusza Korczaka - program wychowawczy s. 39-45; Brzewska Iwona Kamila: Spuścizna Janusza Korczaka w zbiorach Żydowskiego Instytutu Historycznego im. Emanuela Ringelbluma s. 77-100; Ostafiński Witold: Myśli ks. Piotra Skargi inspiracją dla współczesnych polityków, kaznodziejów i wychowawców s. 103-116; Malinowska Maria: Program naprawy Rzeczypospolitej w twórczości księdza Piotra Skargi s. 117-127.

6. JASIŃSKI Zenon, Tosch Frank: Kronika szkolna jako źródło do dziejów edukacji (przykład Zębowic). Opole 2013 Inst. Nauk. Pedagog. Uniw. Opolskiego ss. 294, il.

XIX-XX w.

7. KABACIŃSKA-ŁUCZAK Katarzyna: Sprawozdanie z międzynarodowej konferencji „W kręgu rodziny epok dawnych. Rytm życia - rytmy codzienności. Dzieciństwo”, Kraków, 17-18.10.2012. Biuletyn. Historii Wychowania. [Nr] 29: 2013 s. 277-280.

8. KORCZAK na marginesach. Czytając „Pamiętnik” Starego Doktora. Red. nauk. Zbigniew Rudnicki. Poznań 2013 Wydaw. Nauk. UAM ss. 354, nlb. 2, tabl. 4, il., sum. UAM w Poznaniu. (Psychologia i Pedagogika; nr 190).

9. KRYŃSKA Elwira Jolanta: Ogólnopolska konferencja naukowa „Dziecko - studium

Korczakowskie”, Białystok, 13-14 września 2012 roku. Przegląd Historyczno-Oświatowy. R. 56: 2013 nr 1/2 s. 224-231.

10. KUPISIEWICZ Czesław: Z dziejów teorii i praktyki wychowania. Warszawa 2012 Impuls ss. 322 .

Rec.: Iwanicki Juliusz, Biuletyn Historii Wychowania. [Nr] 29: 2013 s. 160-162.

11. LOYOLA-OPIELA Maria: $Z$ dziejów kształtowania idei wychowania przedszkolnego na ziemiach polskich. Acta Universitatis Nicolai Copernici. Nauki Humanistyczno-Społeczne. Pedagogika. Z. 29: 2013 s. 67-86. 
12. NAWROT-BOROWSKA Monika: II Międzynarodowa Konferencja Naukowa „Wychowanie w rodzinie. Konteksty historyczne i współczesne”, 18-19 maja 2012, Jelenia GóraSzklarska Poręba. Biuletyn Historii Wychowania. [Nr] 29: 2013 s. 272-276.

13. RUSZKOWSKI Andrzej: O kulturze, wychowaniu, oświacie, nauce i zdrowiu. Rozważania z lat 1845-2011. Puławy 2011 nakł. aut.; Drukarnia P.G.H. „Pewnik” ss. 135.

14. RUTA Adam: Konferencja naukowa „Działalność oficyn wydawniczych na rzecz edukacji, szkolnictwa i oświaty w XIX i XX wieku” (Łódź, 15-16 października 2012 roku). Annales Universitatis Paedagogicae Cracoviensis. Folia 146: Studia ad Bibliothecarum

Scientiam Pertinentia. [T.] 11: 2013 s. 229-232.

15. RUTA A.: Tematyka prasoznawcza na Konferencji Naukowej „Działalność oficyn wydawniczych na rzecz edukacji, szkolnictwa i oświaty w XIX i XX wieku" (Łódź, 15-16 października 2012 r.). Rocznik Historii Prasy Polskiej. R. 16: 2013 z. 1 s. 265-268.

16. SCHILLER-WALICKA Joanna, Szumski Jan: Bibliografia zawartości „Rozpraw z Dziejów Oświaty” za lata 1958-2013 (50 tomów). Rozprawy z Dziejów Oświaty. T. 50: 2013 s. 225-284.

17. SKOCZYLAS-KROTLA Edyta: Walory dydaktyczne i wychowawcze książek kucharskich dla dzieci. Częstochowa 2013 Wydaw. im. Stanisława Podobińskiego Akad. im. Jana Długosza ss. 162 , il.

18. WOKÓŁ idei pedagogicznych Sergiusza Hessena [1887-1950]. Red. nauk. Alina Wróbel i Magdalena Błędowska. Łódź 2013 Wydaw. Uniw. Łódzkiego ss. 94, nlb. 1, il. (Sylwetki Łódzkich Pedagogów; t. 1).

Treść: Wróbel A.: Wprowadzenie s. 9-12; Mikołajewicz Wojciech: Dlaczego pedagogika filozoficzna? o filozoficznych podstawach pedagogiki Sergiusza Hessena s. 13-26; Sztobryn Sławomir: Nieznane teksty Sergiusza Hessena. Analiza autentyczności s. 27-34; Wróbel A.: Antropologiczne źródła teologii wychowania w myśli pedagogicznej Sergiusza Hessena s. 35-44; Błędowska M.: Dążenie do wspólnoty jako zadanie procesu wychowawczego w ujęciu Sergiusza Hessena s. 45-52; Rosin Małgorzata: Wybrane poglądy Sergiusza Hessena na wychowanie a współczesna pedagogika humanistyczna s. 53-68; Aneks 1. Kalendarium twórczości Sergiusza Hessena. Oprac. M. Błędowska s. 69-82; Aneks 2. Wybrane rękopisy korespondencji Bogdana Nawroczyńskiego z Sergiuszem Hessenem s. 83-92; Aneks 3. Wybrane kopie dokumentów potwierdzających drogę edukacyjną Sergiusza Hessena s. 93-94.

\section{ROZWÓJ OŚWIATY, WYCHOWANIA I MYŚLI PEDAGOGICZNEJ}

\section{Opracowania ogólne}

19. AKADEMIE nauk, uniwersytety, organizacje nauki. Polsko-rosyjskie relacje w sferze nauki XVIII-XX w. Red. Leszek Zasztowt. Warszawa 2013 IHN PAN; ASPRA-JR ss. 754, nlb. 2. PAN. Kom. Historyków Polski i Rosji, Inst. Hist. Nauki im. Ludwika i Aleksandra Birkenmajerów, Akad. Humanist. im. Aleksandra Gieysztora.

Z treści: Zasztowt L.: Wstęp s. 11-32; Zasztowt L.: Vvedenie s. 33-59; Zamojska Dorota: Rola uczelni rosyjskich w kształtowaniu kadry profesorskiej akademickich szkół państwowych w II Rzeczypospolitej s. 263-270; Jędrychowska Barbara: Między lojalnością a przyzwoitością. Administracja szkolna pod zarządem Imperatorskiego Uniwersytetu Wileńskiego (Swisłocz 1824-1825) s. 287-304; Śliwowska Wiktoria, Śliwowski Renè: Polscy zesłańcy pierwszej połowy XIX wieku jako krzewiciele oświaty na Syberii Wschodniej. Julian Sabiński i jego dziennik s. 307-320; Miąso Józef: Generał Alfons Fortunat Szaniawski (1837-1905) - fundator „wolnego uniwersytetu” w Moskwie. Przyczynek do biografii mecenasa rosyjskiej nauki i edukacji s. 347-361; 
Wiech Stanisław: Miejsce polskich pedagogów w guberniach zabranych w pierwszej połowie XIX w. na przykładzie Aleksandra Mickiewicza (1801-1871) s. 401-420; Niebelski Eugeniusz: Teodor Opęchowski (1853-1914) - lekarz, uczony, profesor uniwersytetów w Dorpacie i Charkowie s. 421-436; Bartnicka Kalina: Polskie i rosyjskie uniwersytety na przełomie XVIII i XIX w. na tle europejskim s. 449-484; Kaštanova Ol'ga S.: Vysšaf i srednââ škola v Korolevstve Pol'skom pri Aleksandre I glazami carskoj administracii s. 499-514; SchillerWalicka Joanna: Uniwersytet Warszawski w systemie uniwersytetów rosyjskich s. 555-572; BaŞenova Hanna: Cesarski Uniwersytet Warszawski w polskiej i rosyjskiej tradycji historycznej oraz w opiniach współczesnej historiografii s. 573-586; Nowiński Franciszek: Polacy w Uniwersytecie Petersburskim przed powstaniem styczniowym s. 587-615; Trynkowski Jan: „Paradisus animae” - czy Sicz dorpacka? Uniwersytet w Dorpacie (Tartu) we wspomnieniach polskich studentów s. 617-627; Kijas Artur: Polscy uczeni z Rosji na Uniwersytecie Poznańskim w okresie międzywojnia s. 629-641; Wołczuk Janina: Wykładowcy radzieccy w Instytucie Filologii Słowiańskiej Uniwersytetu Wrocławskiego (1967-1976) s. 643-648; Zaharov Viktor N.: Iz opyta sotrudničestva pedagogičeskih vuzov Rossii i Pol’šy na rubeže 1980-1990-h godov (Moskovskij oblastnoj pedagogičeskij institut im. N. K. Krupskoj i Vysšafpedagogičeskaâ škola v Ol’štyne) s. 649-661.

20. BIAŁOKUR Marek: Poniatowski i inni. Studia o polskiej polityce, dydaktyce i edukacji historycznej XIX i XX wieku. T. 1. Bielsko-Biała-Opole 2013 Cum Laude; na zlec. PTH. Oddz. ss. 554, il.

21. BOBIK Bogumiła: Rozwój szkolnictwa na Górnym Śląsku w latach 1918-1947. Rudzki Rocznik Muzealny. [R.] 12: 2009/2012 [dr.:] 2013 s. 76-97.

22. BOGUSZEWSKA Anna: Projekty graficzne pozapodręcznikowego wyboru książek zalecanych do edukacji elementarnej w Polsce w latach 1918-1945. Lublin 2013 Wydaw. UMCS s. 431, il. +1 dysk optyczny (CD-ROM).

23. BRANIEWSKI Eugeniusz: Lubomierz. Z dziejów miasta i szkoły. Jelenia Góra-Lubomierz 2013 Ad Rem; Gm. Lubomierz ss. 111, nlb. 1, il.

24. DOSTAŁ Jacek elementarz... Szkolnictwo w Tychach w XX wieku. Scenariusz wystawy Agnieszka Ociepa; współpr. Barbara Kopia, Maria Lipok-Bierwiaczonek, Agnieszka Szymula. Tychy 2013 Muzeum Miej. ss. 40, il.

Katalog wystawy, Tychy, III-IX 2013 r.

25. DZIECKO. [T.] 1. Pod red. Ewy Lewik-Tsirigotis, Grażyny Pietruszewskiej-Kobieli, Zdzisława Włodarczyka. Wieluń 2010 Kolegium Nauczycielskie ss. 607, il.

Z treści: Pietruszewska-Kobiela G.: W stronę dziecka i jego światów - słowo wstępne s. 11-31; JureckaKlimek Magdalena: Życie dziecka w XV wieku (na podstawie polskojęzycznej literatury) s. 127-134; Czajkowska Agnieszka: Trudne powroty. Literackie obrazy szkoły w twórczości poetów XX wieku s. 147-161; Łukarska Beata: O wychowaniu dzieci i rodzinie w literaturze polskiej XVII i XVIII wieku s. 173-186; Cisowska Beata: Obrazy patologicznego wychowania dzieci w powieściach Teodora Tomasza Jeża s. 187-204; Włodarczyk Z.: Między wykluczeniem a akceptacją. Dziecko pozamałżeńskie w krajobrazie społecznym (od Oświecenia do ponowoczesności) s. 291-298; Sadowska Edyta: Na szlakach polskiej szkoły - odyseja tułacza dzieci polskich w ZSRR (1940-1942) w świetle działań pomocowych Ambasady RP w Kujbyszewie s. 299-322; Karaś Magdalena: Dziecko upośledzone umysłowo i problem tolerancji jego odmienności w społeczeństwie ludzi „normalnych” (ujęcie historyczne) s. 335-342; Pękala Anna: Piosenki i pieśni dla dzieci w repertuarze szkolnym w dwudziestoleciu międzywojennym s. 529-544.

26. DZIECKO w historii. Wątek korczakowski. Pod red. Elwiry Jolanty Kryńskiej, Agnieszki Suplickiej, Urszuli Wróblewskiej. Białystok 2013 Wydaw. Uniw. Trans Humana ss. 381, nlb. 2, il.

Z treści: Kryńska E. J.: Wstęp s. 11-17; Wróbel-Lipowa Krystyna: Dziecko żydowskie w świecie dorosłych w drugiej połowie XIX wieku na ziemiach polskich s. 21-32; Galek Czesław: Sytuacja dziecka szkolnego w drugiej połowie XIX wieku w świetle polskiej literatury pamiętnikarskiej i beletrystycznej s. 33-46; Głowacka-Penczyńska Anetta: Dziecko w rodzinie staropolskiej małych miast wielkopolskich s. 47-60; Grysińska-Jarmuła Katarzyna: Patriotyczne czy kosmopolityczne wychowanie dzieci polskich arystokratów w warunkach zaboru pruskiego na przykładzie edukacji hrabiego Bogdana Hutten-Czapskiego s. 61-75; Ausz 
Mariusz: Konwikt pijarski w Krakowie i Rakowicach w latach 1873-1939. Organizacja i założenia wychowawcze s. 76-98; Szewczuk Dariusz: Zapewnić dziecku opiekę - działalność ochronek na terenie Królestwa Polskiego w XIX i na początku XX wieku s. 99-110; Gołdyn Piotr: Profilaktyczne i resocjalizacyjne działania wobec dziewcząt zagrożonych moralnie w latach 1918-1939 s. 111-126; Radziszewska Maria: „Święto Dziecka” w polskich szkołach na Warmii (1929-1939) s. 127-141; Kryńska E. J.: Pedagogika „otwartych drzwi” s. 145-154; Kubis Barbara: Kształtowanie postaw społecznych dzieci i młodzieży w II Rzeczypospolitej - w koncepcji Janusza Korczaka s. 155-174; Walewander Edward: Dziedzictwo Janusza Korczaka. Akcje pomocy dziecku na Lubelszczyźnie w czasie drugiej wojny światowej s. 175-191; Apanel Danuta: Zdrowy styl życia w korczakowskim wychowaniu kolonijnym s. 192-207; Józefowicz Anna: Proces dojrzewania bohatera i jego rozwój. Studium poświęcone dziecku - zapisane w dzienniku „Spowiedź motyla” Janusza Korczaka s. 208-217; Samsel Agata: Białystok w dwudziestoleciu międzywojennym s. 221-238; Lechowski Andrzej: Janusz Korczak w międzywojennym Białymstoku s. 239-251; Suplicka A.: Szkolnictwo żydowskie na Białostocczyźnie s. 252-266; Rogalewska Ewa: Izaak Celnikier uczeń Janusza Korczaka s. 267-278; Wróblewska U.: „Tydzień Dziecka” - idea korczakowska w międzywojennym Białymstoku s. 279-291; Zalewska Dorota Hanna: Dziecko i dotyk zła: proza Gustawa Herlinga-Grudzińskiego wobec problemów współczesnego świata s. 371-381.

27. DZIEJE parafii i kościoła pod wezwaniem Ducha Świętego w Kadzidle. Praca zbior. pod red. Marii Przytockiej. Kadzidło 2012 Parafia Rzymsko-Katolicka pw. Świętego Ducha ss. 408, tabl. 92, il. (Folia Ecclesiastica Pultoviensia; 5).

Z treści: Przytocka Maria: Szkoła parafialna w Kadzidle do 1900 roku s. 81-86; Bogdański Michał: Szkolnictwo w Kadzidle od 1900 roku s. 87-105.

28. DZIEJE Śląska Cieszyńskiego od zarania do czasów współczesnych. T. 5: Śląsk Cieszyński od Wiosny Ludów do I wojny światowej (1848-1918). Red. Krzysztof Nowak, Idzi Panic. Cieszyn 2013 Starostwo Pow. ss. 471, il., sum., Zsfg.

Z treści: Spyra Janusz: Szkolnictwo i oświata s. 355-372.

29. GARBAT Anita, Karpeta Agnieszka: Nauczyciele historii szkół średnich we wspomnieniach uczniów 1918-1989. [W:] Kultura pamięci. Studia i szkice. Pod red. Aldony Chlewickiej i Tomasza Kawskiego. Bydgoszcz 2013 s. 40-57.

30. GLAUER Adelheid, Kischnick Klaus: Das höhere Schulwesen in der Stadt Rosenberg OS 1873-1944. Szkolnictwo średnie w Oleśnie Śląskim. Opole-Osnabrück 2013 Studio Impreso Przemysław Biliczak ss. 544, il.

Tekst częśc. równol. niem., pol.

31. GMINA Puławy owocnie nad Wisłą. Oprac. pod red. Grażyny Hołubowicz-Klizy; aut. Barbara Bąkała [i in.]. Puławy-Góra Puławska 2013 Gm. Bibl. Publ. ss. 305, il., sum., rès., Zsfg., res.

$\mathrm{Z}$ treści: Oświata s. 127-154.

32. GROBELNY Antoni: Stosunki społeczne i religijne, rozwój oświaty oraz życie kulturalne w Jaworzynie Śląskiej do 1945 roku. Rocznik Świdnicki. T. 40: 2012 [dr.:] 2013 s. 138-152.

Od 2 poł. XIX w.

33. GRYFICE. Dzieje miasta. Praca zbiorowa. Pod red. Tadeusza Białeckiego. Szczecin 2013 Urząd M.; Uniw. Szczeciński; Oficyna Wydawnicza AP „Dokument” ss. 623, nlb. 1, il.

Z treści: Cieśliński Antoni: Oświata w Gryficach s. 407-440.

34. HISTORIA wsi Czerwonak zapisana w dokumentach, kronikach i starych fotografiach. Red. Marek Rezler; współpr. Milena Kuleczka [i in.]. Czerwonak 2013 Gm. Czerwonak ss. 140, il., sum.

Z treści: Krause-Matelska Olga, Rezler Marek: Dzieje szkolnictwa w Czerwonaku s. 54-69; Piechowiak Maria: Historia harcerstwa w Czerwonaku s. 124-131. 
35. KALINOWSKA Jadwiga Ambrozja: Troska Zgromadzenia Sióstr Benedyktynek Misjonarek o wyższe wykształcenie swoich członkiń (aspekty historyczno-geograficzny). Studia Redemptorystowskie. Nr 9: 2011 [z.] 1 s. 243-270, Zsfg.

Lata $1917-2010$.

36. KAMIŃSKI Krzysztof: Formacja katechetów zakonnych i świeckich w diecezji włocławskiej w XX wieku. Studia Włocławskie. T. 15: 2013 s. 202-222.

37. KĘDZIERAWSKI Adam: Zarys dziejów szkolnictwa w Pawłowie. Pawłów-Chełm 2013 Sun Solution ss. 324, il. Stow. Przyj. Pawłowa.

Rec.: Piątkowski Leszek, Rocznik Chetmski. T. 17: 2013 s. 393-394.

38. KNOCIŃSKA Anna: W 55 rocznicę działalności najstarszej placówki poradnictwa psychologiczno-pedagogicznego w Poznaniu. Biuletyn Historii Wychowania. [Nr] 29: 2013 s. 135-140.

Zał. w $1957 \mathrm{r}$.

39. KOŁODZIEJ Piotr: Czas na obraz. Dzieło malarskie jako tekst i kontekst w szkolnym kształceniu humanistycznym (1880-1999). Kraków 2013 Collegium Columbinum ss. 320, il. (Biblioteka Tradycji; nr 122).

40. KORZENIOWSKA Maria: Początki szkolnictwa w Lipnicy Małej. Orawa. R. 23/25: 2013 s. $27-28$.

W 1. 1870-1939.

41. KOWAL Anna, Janaczek Stanisław: Placówki oświatowe w Koniecznie w latach 1945-2013. Włoszczowa 2013 Drukarnia Kontur ss. 277, il.

42. KROTOFIL Anna: Historia edukacji teatralnej w Polsce do roku 1945. Zarys historyczny. Przeglad Historyczno-Oświatowy. R. 56: 2013 nr 1/2 s. 108-118.

Od XVI w.

43. KRYŃSKA Elwira Jolanta: Start szkolny w perspektywie historycznej. Przeglad Historyczno-Oświatowy. R. 56: $2013 \mathrm{nr}$ 3/4 s. 98-110.

Na przestrzeni dziejów.

44. KWIATEK Jolanta: Początki gimnazjów na Górnym Śląsku - od jezuickiego „Carolinum” do reform Wilhelma Humboldta. Kwartalnik Opolski. R. 56: 2010 nr 4 s. 43-64, sum.

XVII-XIX w.

45. LEŚNIAK Ewa: Szkolnictwo w Przyszowej. Małopolska. [T.] 15: 2013 s. 177-182.

XV-XXI w.

46. ŁOPATKA Władysław: Na skraju Czchowa i Zakliczyna. Wybrane epizody z historii szkolnictwa i oświaty w gminach Czchów i Zakliczyn oraz cykl wspomnień z lat I i II wojny światowej z terenów byłej Galicji. Zakliczyn-Nowy Sącz 2013 Wydaw. i Drukarnia Nova Sandec ss. 366, il.

47. MARKOWSKA-MANISTA Urszula: Szkolnictwo Łemków i edukacja o Łemkach w warunkach wielokulturowości. [W:] Łemkowie. Pod red. Beaty Machul-Telus. Warszawa 2013 s. $177-196$

48. MICHUŁKA Dorota: Ad usum Delphini. O szkolnej edukacji literackiej - dawniej i dziś. Wrocław 2013 Wydaw. Uniw. Wrocławskiego ss. 438, nlb. 2, tabl. 16, il., sum. (Acta Universitatis Wratislaviensis; no 3457). 
49. NAUKA, edukacja. Kultura w polskiej myśli politycznej XX-XXI wieku. Pod red. Marcina Wichmanowskiego. Lublin 2013 Wydaw. UMCS ss. 368, sum.

Z treści: Maj Ewa: Lucjan Zarzecki [1873-1925] i koncepcja wychowania narodowego s. 15-33; Wichmanowski M.: Oświata w myśli politycznej i działalności Aleksandra Bogusławskiego s. 35-57; Mazurek Marta: Idea nowoczesnej edukacji w myśli oświatowo-wychowawczej Stefanii Sempołowskiej s. 77-92; Bednarzak-Libera Mirosława: „Aż jednością nas zespoli: Naród cały jak rodzinę!”. Oświata i kultura na łamach pisma „Ruch Ludowy” s. 95-129; Zieliński Konrad: Kultura i oświata w działalności Polskiego Biura Agitacji i Propagandy KC Rosyjskiej Komunistycznej Partii (bolszewików) w latach 1918-1925 s. 131-163; Strzelecki Michał: Problematyka wychowawcza w katolickiej myśli społecznej okresu Drugiej Rzeczypospolitej s. 191-216; Podgajna Ewelina: Oświata i wychowanie w myśli politycznej Stronnictwa Chłopskiego (1926-1931) s. 217-232; Strzelecka Małgorzata: Problematyka oświatowo-wychowawcza na łamach „Tygodnika Powszechnego" w latach 1945-1953 s. 233-261; Stępka Stanisław: Oświata i kultura w koncepcjach solidarnościowego nurtu ruchu ludowego s. 263-277; Sikorski Tomasz: „Edukacja Jutra”. Problematyka oświaty w myśli politycznej rodzimego nurtu demokratycznego konserwatyzmu po 1989 roku s. 279-301; Mieczkowski Antoni: Nauka, oświata i kultura w myśli politycznej Porozumienia Centrum s. 303-313; Koziełło Tomasz: Koncepcje programowe Ministerstwa Edukacji Narodowej pod kierownictwem Romana Giertycha (2006-2007) s. $335-353$.

50. NICIEJA Halina: Świat starych fotografii. Pierwszy dzień w szkole. Rocznik Dzierżoniowski. T. 18: 2008 [dr.:] 2009 s. 268-271.

51. OD STAROŻYTNEJ myśli filozoficznej do współczesnych rozwiązań legislacyjnych. From the philosophical thought of antiquity to contemporary legislative solutions. Pod red. Barbary Jędrychowskiej, Ewy Jurczyk-Romanowskiej. Wrocław-Jelenia Góra 2013 Uniw. Wrocławski; Karkonoska Państ. Szkoła Wyższa ss. 339, il., sum. Zakł. Historii Edukacji Inst. Pedagogiki Uniw. Wrocławskiego, Wydz. Nauk Humanist. i Społ. Karkonoskiej Państ. Szkoły Wyższej w Jeleniej Górze. (Wychowanie w Rodzinie; t. 7 (1/2013)).

Z treści: Jędrychowska B.: Wstęp s. 9-14; Bartkowiak Edyta: Wychowanie w rodzinie według Janusza Korczaka s. 83-105; Ryś Jan: Rodzina szlachecka w świetle staropolskich poradników gospodarskich s. 109-126; Nawrot-Borowska Monika: Sprawy tajemne i nieczyste. Rola rodziny w wychowaniu seksualnym dzieci w drugiej połowie XIX i na początku XX wieku w świetle poradników. Zarys problematyki s. 127-162; Kalinowska-Witek Barbara: Funkcje i dysfunkcje rodziny w świetle czasopism kobiecych i rodzinnych Królestwa Polskiego z lat 1864-1914 s. 163-179; Bołdyrew Aneta: Dziecko w rodzinie robotniczej w Królestwie Polskim na przełomie XIX i XX wieku. Warunki życia i normy wychowania s. 181-213; Okrasa Marzena: Współpraca rodziny i szkoły na przykładzie szkół w Lublinie w okresie II Rzeczypospolitej s. 217-234; Samsel Agata: Rodziny potrzebujące wsparcia w II Rzeczypospolitej - jakość życia, realizacja podstawowych funkcji, opieka społeczna s. 235-258; Piwowarczyk Mirosław: Działania Związku Pracy Obywatelskiej Kobiet na rzecz pomocy rodzinie s. 259-291; Jurczyk-Romanowska E.: Instytucja pochodzenia dziecka w polskim prawie rodzinnym w latach 1946-1965 s. 295-330.

52. OŚWIATA grodziska wczoraj i dziś. Zespół red. Katarzyna Jezierska [i in.]. Grodzisk Mazowiecki 2013 Urząd Miej. ss. 79, il.

XX-XXI w.

53. PIĘKNA jest Szczyrzycka Ziemia. Red. Waleria Cudek [i in.]. Nowy Sącz 2012 Stow. Zw. Szczyrzycan; Urząd Gm. Jodłownik ss. 207, nlb. 1, il.

Toż. Wyd. 2. popr. i uzup. Nowy Sącz 2012 Stow. Zw. Szczyrzycan; Urząd Gm. Jodłownik; Wydaw. i Drukarnia Novy Sandec ss. 254, il.

Z treści: Adamczyk Alina: Rys historyczny Szkoły Powszechnej w Szczyrzycu s. 51-54; Wspomnienia Henryka Rogalińskiego - kierownika Szkoły Podstawowej w Szczyrzycu dotyczące budowy szkoły w Szczyrzycu w latach 1936-1948 s. 55-62; Czachura Stanisław, Cudek Waleria: Szkolnictwo w Szczyrzycu s. 63-80; Cudek Ignacy: Tajne nauczanie na terenie Szczyrzyca s. 81-82; Czachura S.: Zasadnicza Szkoła Zawodowa s. 83-84; Frys Zuzanna: Zjazdy Szczyrzyckie s. 92-96; Wspomnienia ze zjazdów koleżeńskich absolwentów oraz uczniów Gimnazjum i Liceum O.O. w Szczyrzycu s. 97-105. 
54. POPEK Joanna: „Tradycyjny” model kształcenia dziewcząt w liberalnym społeczeństwie. Niepokalański system pedagogiczny. Kwartalnik Opolski. R. 58: 2012 nr 1 s. 19-27, sum.

XIX-XX w.

55. PUSZKA Alicja: Działalność opiekuńczo-wychowawcza Zakonu Sióstr Miłosierdzia Wincentego á Paulo w Lublinie w XIX i XX wieku. Lublin 2013 Wydaw. KUL ss. 551, nlb. 1, il., sum. KUL Jana Pawła II. Wydz. Nauk Humanist.

56. QUIRINI-POPŁAWSKA Danuta: Studia Polaków na Uniwersytecie Padewskim w XV i XVI wieku. Stan badań oraz wstępne hipotezy. Prace Komisji Środkowoeuropejskiej PAU. T. 21: 2013 s. 19-30, sum.

57. ROGOZIŃSKA Anna: Misja wychowawcza urszulanek Unii Rzymskiej w Krakowie. [W:] Św. Aniela Merici i jej dzieło realizowane przez polskie Urszulanki Unii Rzymskiej. Red. Grażyna Weronika Dryl, Wojciech Misztal. Kraków 2013 s. 241-278.

58. ROSTROPOWICZ-MIŚKO Marta: Rodzina na Śląsku w latach 1939-1947. Dezintegracja -Migracja - Codzienność. Rocznik Łubowicki. [T.] 8: 2010 s. 253-256.

Sprawozdanie z konferencji, Opole, 21-22 X $2010 \mathrm{r}$.

59. SANDER Elżbieta: Działalność edukacyjna i wychowawcza krakowskich klarysek. Kraków 2010 Unum ss. 306, il.

Toż. Wyd. 2, popr. Kraków 2013 ss. 318, nlb. 2, il., res.

XX-XXI w.

60. SKROBISZ Bogdan: Sto lat oświaty we Włoszczowicach 1912-2012. Kazimierza Wielka 2013 Kazimierska Agencja Drukarska ss. 96, il.

61. „STARE” i „nowe” - czasopisma dla dzieci i młodzieży. Pod red. Bożeny Olszewskiej i Elżbiety Luckiej-Zając. Opole 2013 Wydaw. Uniw. Opolskiego ss. 421, il., sum. Uniw. Opolski.

Z treści: Olszewska B.: Słowo wstępne s. 7-10; Waksmund Ryszard: O tytułach czasopism dla dzieci s. 13-26; Sokół Zofia: Czasopisma dla młodzieży szkolnej w Polsce w latach 1989-2009 s. 27-67; GajakToczek Małgorzata: Jeden rok życia „Dziennika dla Dzieci” Stanisława Jachowicza s. 71-84; Kucharska Małgorzata: Model nowoczesnego czasopisma dla dzieci i młodzieży na przykładzie „Płomyka” (1917-1939) s. 85-100; Kruszyńska Elżbieta: Dydaktyczno-wychowawcza rola czasopism dla dzieci w dwudziestoleciu międzywojennym (na przykładzie „Płomyczka”) s. 101-112; Olszewska B.: „Płomyczkowy” kalendarz liturgiczny. W kręgu wybranych tematów i motywów literatury religijnej międzywojennego „Płomyczka” (19171939) s. 113-133; Ługowska Jolanta: Janusza Korczaka koncepcja „pisma dzieci”. Na podstawie „Małego Przeglądu" (1926-1939) s. 135-148; Dworakowska Dominika: Kilka uwag na temat edukacyjnej działalności „Świerszczyka” (1945-2010) s. 151-159; Zabawa Krystyna: Utwory literackie w wybranych współczesnych czasopismach dla dzieci w wieku wczesnoszkolnym s. 161-173; Ignasiak Aleksandra: ,[...] Tak prymitywne, że aż bezbronne?" - analiza zawartości popularnych czasopism młodzieżowych s. 175-189; Michułka Dorota: „Victor Junior” i interdyscyplinarność. W stronę hipertekstu? 191-215; Urbańczyk Lidia: Czasopisma fantastyczne jako element dyskursu fanizmu s. 217-230; Tałuć Katarzyna: Obszary wolności słowa. Niezależna polska prasa młodzieżowa z lat 80. XX wieku (rekonesans badawczy) s. 233-249; Hajduk-Nijakowska Janina: Sytuacja prasy dziecięco-młodzieżowej na wolnym rynku mediów w Polsce s. 251-266; Bortliczek Małgorzata: Sposoby konceptualizacji rzeczywistości w czasopismach dla dzieci s. 267-285; Karczewska Agnieszka: „Stary-nowy” kraj - obraz Erec Israel w „Chwilce Dzieci i Młodzieży” (1925-1937) s. 301-318; Krzyżyk Danuta, Synowiec Helena: „Młody Krajoznawca Śląski” źródłem wiedzy o kulturze regionu s. 319-344; Kossakowska-Jarosz Krystyna: Skromne edytorstwo w służbie idei regionalizmu. Młodzieżowe roczniki organizacyjne na międzywojennym Górnym Śląsku s. 345-362; Woźniakowski Krzysztof: Czasopiśmiennictwo dziecięce polskiego uchodźstwa na Węgrzech okresu II wojny światowej s. 363-389; Kłakówna Zofia Agnieszka: Szkolna passa dla prasy s. 393-401; Morawska Iwona: Czasopisma młodzieżowe w kształceniu nauczycieli s. 403-409. 
62. SZKOLNICTWO i oświata na Pomorzu (XVI-XX w.). XII Konferencja KaszubskoPomorska. Pod red. Zenona Romanowa. Słupsk 2013 Wydaw. Nauk. Akad. Pomorskiej ss. 232, il. Muzeum Pomorza Środkowego w Słupsku, Inst. Historii i Politologii Akad. Pomorskiej w Słupsku.

Treść: Romanow Z.: Wstęp s. 5-9; Szultka Zygmunt: Szkolnictwo słupskie w okresie początków reformacji i po jej proklamacji w Księstwie Pomorskim s. 11-32; Kallaur Kazimierz: Szkolnictwo elementarne w powiecie słupskim w drugiej połowie XVIII wieku s. 33-47; Tomaszewski Roman: Konserwatyzm w strategiach wychowania na Pomorzu 1653-1945 s. 49-61; Żukowska Justyna: Szkolnictwo jezuickie w Prusach Królewskich w XVI-XVIII wieku s. 63-77; Pencarski Kacper: Prawodawstwo prezydium rejencji koszalińskiej wobec szkolnictwa rejencji w latach 1918-1933 s. 79-89; Skóra Wojciech: Słupski proces Jana Bauera z 1932 roku jako element działań administracji i mediów Niemiec oraz Polski s. 91-114; Romanow Z.: Nauczyciele prywatnych katolickich szkół powszechnych z polskim językiem wykładowym w powiecie bytowskim i złotowskim w latach 1929-1939 i ich późniejsze losy s. 115-134; Hejger Maciej: Szkolnictwo z niemieckim językiem nauczania w województwie koszalińskim w latach 1950-1959 s. 135-144; BurzyńskaWentland Lidia, Gorloff Elżbieta: Uwarunkowania powstania i rozwoju szkolnictwa niemieckiego w województwie koszalińskim w latach 1950-1959 s. 145-154; Cyba Witold: Szkolnictwo ukraińskie na Pomorzu Zachodnim w latach 1952-1989 s. 155-165; Mastalerz-Krystjańczuk Małgorzata: Pomorze i stosunki polskoniemieckie w podręcznikach szkolnych z lat 1945-1956 s. 167-186; Szulc Paweł: Rola Wszechnicy Radiowej w stalinowskim systemie oświaty w województwie szczecińskim s. 187-194; Król Joanna: Społecznopolityczne uwarunkowania rozwoju szkół średnich ogólnokształcących w województwie szczecińskim w latach 1945-1989 s. 195-207; Skonieczny Tomasz: Kształtowanie powojennej wiejskiej sieci szkolnej na przykładzie północno-zachodniej części powiatu koszalińskiego (1945-2011) s. 209-228.

63. SZKOLNICTWO specjalne na Pomorzu Zachodnim w latach 1945-2010. Praca zbiorowa. Pod red. Urszuli Morcinek. Szczecin 2013 „Pedagogium” Wydaw. OR TWP ss. 523, il.

Wyższa Szkoła Humanist. Tow. Wiedzy Powszechnej w Szczecinie.

Z treści: Morcinek U.: Słowo wstępne s. 9-14; Plewka Czesław: Społeczno-polityczne i organizacyjno-administracyjne uwarunkowania przemian oświatowych województwa zachodniopomorskiego w latach 1945-2010 s. 17-70; Penar Karol: Szkolnictwo specjalne na Pomorzu Zachodnim w latach 1945-2005 s. 71-111; Eckert Urszula: Przemiany zachodzące w przygotowaniu kadr dla kształcenia specjalnego s. 113-118; Łaś Helena: Kształcenie pedagogów specjalnych na Pomorzu Zachodnim (w latach 1964-2005) s. 119-135; Penar K.: Szkolnictwo specjalne dla dzieci i młodzieży z niepełnosprawnością sensoryczną s. 139-163; Morcinek U.: Szkolnictwo specjalne dla dzieci i młodzieży z niepełnosprawnością intelektualną s. 167-264; Kowańdy Kazimierz, Morcinek U.: Placówki edukacyjno-wychowawcze dla młodzieży niedostosowanej społecznie s. 267-289; Morcinek U., Penar K.: Rozwój placówek specjalnych dla dzieci i młodzieży z niepełnosprawnością ruchową i somatyczną s. 293-316; Wspomnienia pionierów szkolnictwa specjalnego Pomorza Zachodniego s. $399-440$.

64. SZYLAR Anna: Działalność wychowawczo-edukacyjna żeńskich zgromadzeń zakonnych w Małopolsce w okresie potrydenckim do 1815 roku. Kraków 2012 Secesja ss. 465, il.

Rec.: Królikowski Janusz, Hereditas Monasteriorum. Vol. 2: 2013 s. 375-378.

65. ŚLADAMI przeszłości po gminie Podedwórze. Monografia historyczna. Red. Jolanta Jędrak. Podedwórze-Lublin 2013 Gm. Bibl. Publ.; Olech ss. 224, tabl. 24, il. Gm. Bibl. Publ. w Podedwórzu.

Z treści: Latawiec Krzysztof: Dzieje oświaty. [W aneksie dokumenty z 1935, 1942, 1966 i 1972 r.] s. $77-160$.

66. TARGOWSKI Andrzej: Różnice w kształceniu inżynierów w Polsce i w USA. Rocznik Polskiego Towarzystwa Naukowego na Obczyźnie. R. 55: 2011/2012 [dr.:] 2013 s. 82-96.

Od $1918 \mathrm{r}$.

67. TARKA Krzysztof: Szkolnictwo litewskie w Polsce. [W:] Litwini. Pod red. Lecha M. Nijakowskiego. Warszawa 2013 s. 43-58. 
68. TOKARSKI Stanisław: Szkolnictwo w Niedomicach w latach 1912-2012. Niedomice 2013 Zespół Szkoły Podstawowej i Gimnazjum Publ. ss. 416, il.

69. [TRZYDZIEŚCI] 30 lat seminariów duchownych na Pomorzu Zachodnim. Pod red. Tadeusza Ceynowy. Koszalin-Radom 2013 Bibl. Wyższego Seminarium Duchownego; Inst. Technologii Eksploatacji - Państ. Inst. Badawczy ss. 219, il.

Księga pamiątkowa z okazji 30-lecia Wyższego Seminarium Duchownego Diecezji KoszalińskoKołobrzeskiej w Koszalinie.

Treść: Jastrząb Dariusz: Wstęp s. 9-10; Kopiec Jan: Problematyka dotycząca seminarium duchownego w relacjach biskupów wrocławskich „,ad limina Apostolorum” s. 11-23; Bończa-Bystrzycki Lech: Wykształcenie duchowieństwa katolickiego duszpasterzującego na Pomorzu Zachodnim w XIX wieku s. 25-32; Kołodziej Bernard: Towarzystwo Chrystusowe w służbie Kościoła na Pomorzu Zachodnim s. 33-38; ŚmierzchalskiWachocz Dariusz: Seminarium gorzowskie jako Alma Mater dla Kościoła szczecińskiego i koszalińskiego s. 39-47; Wejman Grzegorz: 30-lecie Arcybiskupiego Wyższego Seminarium Duchownego w Szczecinie s. 49-69; Ceynowa T.: 30-lecie Wyższego Seminarium Duchownego w Koszalinie s. 71-125; Tomaszewski Tomasz: Rodzina Przyjaciół Seminarium Koszalińskiego s. 127-139; Florianowicz Magdalena, Zielonka Monika: Biblioteka Wyższego Seminarium Duchownego w Koszalinie s. 141-147; Kroplewski Zdzisław: Formacja indywidualna $\mathrm{i}$ wspólnotowa $\mathrm{w}$ seminarium duchownym na przykładzie programu Wyższego Seminarium Duchownego w Koszalinie w latach 1993-2003 s. 151-163; Cieślik Paweł: Trzydziestolecie seminariów (2011 rok) s. 165-167; Ceynowa T.: Ważniejsze wydarzenia Wyższego Seminarium Duchownego w Koszalinie s. 171-184; Fotografie s. 187-189; Tableau 1984-2011 s. 193-219.

70. W KRĘGU historii wychowania. Pod red. Hanny Markiewiczowej. Warszawa 2013 Wydaw. Akad. Pedagogiki Specjalnej ss. 221, nlb. 3, sum.

Z treści: Markiewiczowa H.: Wstęp s. 7-8; Żółciński Zbigniew J.: Stereotyp roli wychowawczej ojca w świetle zbiorów przysłów Samuela Adalberga i Franciszka Brzozowskiego s. 41-53; Poznański Karol: Nieudane próby uruchomienia publicznych czytelni w Królestwie Polskim w okresie międzypowstaniowym s. 55-67; Szarkowska Agnieszka: Kobiety w szkołach prywatnych II RP s. 69-80; Markiewiczowa H.: Działalność Koła Polskiej Macierzy Szkolnej w Równem na Wołyniu w latach 1924-1933 w świetle sprawozdań towarzystwa s. 81-115; Nadolska Agnieszka: Germanizacja dzieci polskich w czasie okupacji hitlerowskiej s. 117-129; Walkowiak Wanda: Nauczyciele tajnego gimnazjum w Wiśniewie s. 131-143; Czarnecka Iwona: Działalność Polskiego Związku Głuchych w latach 1946-1965 s. 145-159; Kulbaka Jacek: Realizacja uchwały Sejmu Polskiej Rzeczypospolitej Ludowej z dnia 16 IX 1982 roku w sprawie inwalidów i osób niepełnosprawnych s. 161-181; Misiaszek Kazimierz: Nauczanie religii katolickiej i katecheza parafialna w Polskiej Rzeczypospolitej Ludowej s. 183-196; Malinowski Ludwik: Edukacja - oczekiwania a możliwości s. $197-217$.

71. WAGNER Barbara: Szkoła publiczna w Polsce w XX wieku. Zarys dziejów społecznych. Warszawa 2013 Uniw. Warszawski ss. 342, tabl. 12, il., sum.

Rec.: Stępnik Andrzej, Res Historica. Nr 36: 2013 s. 344-349.

72. WIERZBOWSKA Ilona: Bydgoscy nauczyciele w świetle dokumentów i relacji Muzeum Oświaty w Bydgoszczy. [W:] Kultura pamięci. Studia i szkice. Pod red. Aldony Chlewickiej i Tomasza Kawskiego. Bydgoszcz 2013 s. 58-62.

73. [WILCZKOWSKA Anastazja] A. E. Vil'čkovs'ka: Muzične vihovannâ učniv zagal'noosvitnih škil Pol'ši. (Istoričnij aspekt). Monografiâ. Piotrków Trybunalski 2013 Nauk. Wydaw. Piotrkowskie przy Filii Uniw. Jana Kochanowskiego ss. 293, il., streszcz., sum.

74. WODZIEŃ Edward: Dębica. Nasze szkolnictwo do końca XX wieku. Dębica 2013 Muzeum Region.; Tow. Przyj. Ziemi Dębickiej ss. 650, il. (Biblioteka Dębickich Gryfów; 6).

75. WOKÓŁ historii... Historia wokół. Studia. Red. Adrian Konopka i Agnieszka Brzostek. Białystok 2013 Wydaw. Prymat Mariusz Śliwowski ss. 480, il.

Księga jubileuszowa 45-lecia pracy pedagogicznej i naukowej prof. dr hab. Hanny Konopki. 
Z treści: Konopka A.: Przypadki z historii s. 9-47; Bibliografia prac Hanny Konopki za lata 1980-2013. Oprac. A. Konopka s. 49-83; Cesarz-Maternicka Elżbieta, Maternicki Jerzy: Rosja w myśli historycznej i politycznej Waleriana Kalinki s. 65-89; Gnatowski Michał: Antyreligijna działalność władz radzieckich w regionie białostockim w latach 1939-1941 w świetle zachowanych źródeł radzieckich s. 91-107; Wrzosek Mieczysław: Noc morderców. Kaźń polskich profesorów we Lwowie i Holokaust w Galicji Wschodniej s. 109-125; Kujawska Maria: Kształcenie nauczycieli dla przyszłości s. 121-125; Suchoński Adam: Powstanie styczniowe w zagranicznych podręcznikach do nauczania historii s. 127-132; Pańko Grażyna: O tym, co daje radość życia w świetle pamiętników i wspomnień s. 133-144; Wagner Barbara: Obrona powietrzna i przeciwgazowa. Edukacyjne aspekty bezpieczeństwa narodowego w ostatnich latach II Rzeczypospolitej s. 145-156; Wójcik-Łagan Hanna: Związki nauki z nauczaniem w powojennych wypowiedziach Żanny Kormanowej (lata 40. i 50. XX w.) s. 157-174; Burda Bogumiła: Społeczne i emancypacyjne aspekty edukacji Polek w XIX-XX wieku s. 253-260; Puszka Alicja: Wychowanie dzieci i młodzieży w XIX i XX w. na przykładzie funkcjonowania Domu Dziecka im. Janusza Korczaka w Lublinie s. 261-283; Błachowska Katarzyna: Syberia we współczesnej edukacji historycznej s. 285-296; Glimos-Nadgórska Anna: Autonomia województwa śląskiego a działania unifikacyjne szkolnictwa powszechnego z ustawodawstwem Rzeczypospolitej (1922-1939) s. 311-318; Konieczka-Śliwińska Danuta: Nauczanie o regionie w okresie międzywojennym w świetle sprawozdań dyrekcji gimnazjów państwowych s. 371-382; Bieniek Maria, Jóźwiak Iwona: Działalność charytatywno-opiekuńcza Kościoła rzymskokatolickiego na Warmii i Mazurach w pierwszych latach powojennych - zarys problematyki s. 383-397; Techmańska Barbara: Młodzież zagłębia miedziowego „w walce” z ustrojem socjalistycznym w świetle akt Służby Bezpieczeństwa s. 399-405.

76. Z DZIEJÓW szkolnictwa w Rybniku. Praca zbior. pod red. Dawida Kellera. Rybnik 2013 Muzeum ss. 201, il. (Zeszyty Rybnickie. Studia).

Treść: Kloch Bogdan: Słowo wstępne s. 7-8; Keller D.: Wprowadzenie s. 9-10; Kloch B.: Elementarne szkolnictwo (katolickie) w Rybniku i okolicach, w świetle publikowanych urzędowych zestawień (schematyzmów) do wybuchu wielkiej wojny (1914 r.) s. 11-49; Keller D.: Królewskie Progimnazjum i Gimnazjum (w organizacji) w Rybniku w latach 1908-1922 - szkic do dziejów zapomnianej szkoły s. 51-68; Kuczera Piotr, Rojek Henryk: Zarys dziejów Szkoły Rolniczej w Popielowie s. 69-77; Kulik Ewa: Nauczycielstwo międzywojnia w powiecie rybnickim - zarys s. 79-96; Hojka Zbigniew, Kaczor Sławomir: Szkolnictwo handlowe w Rybniku w latach 1923-1939. Geneza i funkcjonowanie s. 97-130; Frużyński Adam: Przygotowanie do wykonywania zawodu górnika w rybnickich kopalniach do 1945 r. s. 131-152; Abrahamowicz Jakub: System oświaty na kartach sprawozdań rocznych rybnickich liceów w latach 1950-1965 s. 153-158; Abrahamowicz J.: Szkoły - „Pomnik Tysiąclecia” w Rybniku w latach 1958-1967 s. 159-176; GrabowskaRogus Anna: Powojenne szkolnictwo zawodowe w Rybniku - struktura i rozwój w latach 1945-1989 s. 177-201.

77. ZARYS historii nauczania medycyny w Polsce do roku 1939. Wybrane zagadnienia. Pod red. Andrzeja Śródki. Kraków 2012 Wydaw. UJ ss. 325, il.

Treść: Śródka A.: Wstęp s. 7-8; Zwolski Stanisław: Medycyna przedakademicka w średniowiecznej Polsce s. 9-16; Gajda Zdzisław: Wydział Lekarski Akademii Krakowskiej - od założenia do reform Komisji Edukacji Narodowej s. 17-26; Zwolski S.: Nauczanie medycyny w Polsce - od Komisji Edukacji Narodowej do wybuchu drugiej wojny światowej s. 27-57; Gryglewski Ryszard W.: Anatomia prawidłowa s. 59-80; Śródka A.: Histologia s. 81-91; Śródka A.: Fizjologia s. 93-108; Gryglewski R. W.: Anatomia patologiczna s. 109-126; Schmidt-Pospuła Maria Dorota: Mikrobiologia s. 127-148; Nowakowska-Zamachowska Monika: Interna s. 149-176; Lejman Władysław: Chirurgia s. 177-230; Nowakowska-Zamachowska M.: Ginekologia i położnictwo s. 231-250; Śródka A.: Neurologia s. 251-272; Gryglewski R. W.: Filozofia medycyny s. 273-291; Gryglewski R. W.: Historia medycyny s. 293-311.

78. ŻNIN. [T. 1]: 750 lat dziejów miasta. Praca zbior. pod red. Tadeusza Janickiego. Żnin 2013 Gm. Żnin; Miej. i Pow. Bibl. Publ. ss. 569, nlb. 1, tabl. 2, il.

Z treści: Wilgórski Marek: System edukacji szkolnej s. 313-361.

79. ŻYDOWSKIE dziecko. Red. Anna Jeziorkowska-Polakowska, Agnieszka Karczewska. Lublin 2013 Tow. Nauk. KUL ss. 329. Tow. Nauk. KUL. Pracownia Literatury Pol.-Żydowskiej. (Studia; t. 5) (Źródła i Monografie; 405).

Treść: Jeziorkowska-Polakowska A., Karczewska A.: Trójwymiarowy portret dziecka żydowskiego. Wstęp s. 13-18; Geller Ewa: Dziecko jako przedmiot zainteresowania późnorenesansowej medycyny żydowskiej 
s. 21-29; Pieńkowska Olga: Dzieciństwo uprzywilejowane - pierwsze lata życia reb Dowa ber Birkentala i Salomona Majmona. Próba rekonstrukcji na podstawie pamiętników s. 33-40; Jakimyszyn Anna: Dziecko jako temat XVIII i XIX-wiecznych „tchines” s. 41-51; Rybińska Agata: Pomiędzy integracją a dysymilacją edukacja religijna dzieci żydowskich w XIX-wiecznym Wrocławiu s. 53-62; Gadowska Irmina: Za bramą domu życia. Dziecięce nagrobki na cmentarzu żydowskim w Łodzi przy ulicy Brackiej. Forma i znaczenie s. 63-74; Tuszewicki Marek: Dziecko jako przedmiot troski od chwili poczęcia do narodzin w świetle żydowskich poradników z przełomu XIX i XX wieku s. 75-84; Waksmund Ryszard: Bycie Żydem w świetle wspomnień o dzieciństwie s. 85-94; Żurek Sławomir Jacek: Dziecko w poezji polsko-żydowskiej dwudziestolecia międzywojennego s. 95-109; Karczewska A.: „Wieczór cudów”. O twórczości Maurycego Szymla dla dzieci s. 111-125; Jeziorkowska-Polakowska A.: „Franiu, a te Duszki?...” - Franciszki Arnsztajnowej twórczość dla dzieci s. 127-140; Szabłowska-Zaremba Monika: Dziecko - nasz obowiązek i radość. O walce o prawa dzieci na łamach „Naszego Przeglądu” (1923-1939) s. 141-157; Krasowska Anna: Obraz dziecka żydowskiego w wybranych tekstach szmoncesowych s. 159-167; Grądzka Martyna: Utracone dzieciństwo. Dziecko żydowskie w KL Płaszów s. 171-182; Kudyba Wojciech: Gra i tożsamość. Dzieci żydowskie w Zakładzie dla Sierot Wojennych w Turkowicach s. 183-189; Kowalska-Leder Justyna: Dzienniki Dzieci Holokaustu - funkcje praktyki diarystycznej s. 191-199; Konopczyńska-Tota Ewelina: „Zasmucam się na widok masy czekającej na śmierć". Zagłada w oczach Rutki Laskier s. 201-210; Makieła Karolina: Wpływ wojny na psychikę dzieci analiza prozy Wilhelma Dichtera s. 213-222; Sawa Marek: Dwa literackie obrazy przestrzeni getta w narracjach Dzieci Holokaustu s. 223-232; Dobiegała Anna: Dzieci Holokaustu w prozie Hanny Krall s. 233-243; Wójcik-Dudek Małgorzata: Kiedy mały Srulek staje się bohaterem literackim - Holokaust w literaturze dla dzieci i młodzieży s. 245-255; Wirski Mariusz: Sztuka jako wyzwolenie z wojennej traumy. „Lista Schindlera” i „Dziewczynka w czerwonym płaszczyku” s. 257-264; Dittrich Wanda: Weiser Dawidek - odmieniec i święty? s. 265-271; Latocha Anna: (Re)konstruowanie tożsamości żydowskiego dziecka w świadectwach emigrantów Marca ,68 s. 273-283; Lenart Agnieszka: Obserwacje wychowawcze Diny Rubinej ,żydowskiej matki na rosyjskim zakwasie” s. 285-294; Krzemiński Maciej: Dojrzewanie do ciała, cierpienia i winy w „Odosobnieniu” Georgesa-Arthura Goldschmidta s. 295-306; Bibliografia s. 307-317.

\section{Okres do 1795 roku}

80. BORAWSKA Teresa: Studia uniwersyteckie młodzieży grudziądzkiej w średniowieczu i u progu czasów nowożytnych (XIV-XVI wiek). Rocznik Grudziądzki. T. 20: 2012 s. 43-65.

81. BRONIARCZYK Marcin: Wykształcenie świeckich senatorów z Wielkopolski za Władysława IV. [W:] Kultura parlamentarna epoki staropolskiej. Studia pod red. Andrzeja Stroynowskiego. Warszawa 2013 s. 209-221.

82. CHMIELEWSKI Witold: Konferencja naukowa w 240. rocznicę utworzenia Komisji Edukacji Narodowej, Warszawa, 18 października 2013 roku. Przegląd Historyczno-Oświatowy. R. 56: $2013 \mathrm{nr} 3 / 4$ s. 206-208.

83. DEMIDZIUK Krzysztof: Nauczanie archeologii prahistorycznej i średniowiecznej we Wrocławiu. Tradycja i współczesność. Silesia Antiqua. T. 48: 2012 s. 218-231.

XIX-XXI w.

84. DURBAS Małgorzata: Akademia Stanisława w Nancy (1750-1766). Kraków 2013 Libron

- Filip Lohner ss. 429 , nlb. 1, il., rès.

Stanisława Leszczyńskiego.

85. GRAFF Tomasz: Wokół staropolskich fundacji i benefaktorów Szkół Nowodworskich w Krakowie. Folia Historica Cracoviensia. Vol. 19: 2013 s. 159-176, sum.

Lata $1586-1777$. 
86. KACZYŃSKI Paweł: W szkole czy w domu? O modelach edukacji w powieściach czasów stanisławowskich. Acta Universitatis Wratislaviensis. No 3094: Prace Literackie. [T.] 48: 2008 s. $25-31$.

87. KAMLER Anna: Szesnastowieczne książki szkolne jako przykłady druków codziennego użytku. [W:] Ars historiae - historia artis. Prace ofiarowane profesorowi Andrzejowi Wyrobiszowi. Pod red. Ewy Dubas-Urwanowicz i Józefa Maroszka. Białystok 2012 s. 131-137.

88. KICIŃSKA Urszula: Rola wdowy w rodzinie i społeczeństwie staropolskim na podstawie polskich drukowanych oracji pogrzebowych XVII w. Sensus Historiae. Vol. 13: 2013 [nr] 4 s. $135-148$, sum.

89. KICIŃSKA U.: „Złości, która się więc pokazuje w dziateczkach nie tak winien ojciec jako matka" - wpływ matki na wychowanie swych dzieci w polskich drukowanych oracjach pogrzebowych XVII wieku. Biuletyn Historii Wychowania. [Nr] 29: 2013 s. 73-83, sum.

90. KUKLO Cezary: O porzucaniu dzieci w osiemnastowiecznej Warszawie. [W:] Ars historiae - historia artis. Prace ofiarowane profesorowi Andrzejowi Wyrobiszowi. Pod red. Ewy Dubas-Urwanowicz i Józefa Maroszka. Białystok 2012 s. 235-253.

91. LORENS Beata: Problemy wychowawcze w szkołach bazyliańskich w drugiej połowie XVIII wieku na przykładzie kolegium w Buczaczu. Biuletyn Historii Wychowania. [Nr] 29: 2013 s. $29-42$, sum.

92. NOWICKI Michał: Retoryka i historia w służbie wychowania w Polsce na podstawie analizy skryptu wykładów retoryki w Kolegium Jezuitów w Poznaniu z 1679 roku. Biuletyn Historii Wychowania. [Nr] 29: 2013 s. 15-27, sum.

93. ORCZYK Adam: Kształcenie i formacja duchownych w średniowieczu. Lublin 2013 Polihymnia ss. 218.

94. PIŁATOWICZ Józef: Próby utworzenia szkoły wojskowo-technicznej w Polsce do połowy XVIII wieku. [W:] Z Chrystusem w służbie Bogu i ludziom. Księga Jubileuszowa z okazji 60. rocznicy urodzin i 30-lecia pracy naukowej księdza profesora Romana Krawczyka. Red. Janusz Gmitruk, Anna Wielgosz. Siedlce-Warszawa 2012 s. 431-444.

95. RICHTER Manfred: Johann Amos Comenius und das Colloquium von Thorn 1645. Ein Beitrag zum Ökumenismus. Red. t. Roman Mnich. Siedlce 2013 Stow. Tutajteraz; Inst. Neofilologii i Badań Interdyscyplinarnych Uniw. Przyrodniczo-Humanist. ss. 545, il., riass., shrnutî, sum. Pracownia Comeniologii i Badań Interdyscyplinarnych. Uniw. Przyrodniczo-Humanist. w Siedlcach, Deutsche Comenius-Gesellschaft. (Labyrinthi; t. 1 (2013)).

96. RYŚ Jan: Nauka, modlitwa i rekreacja. Studium o czasie wolnym i obyczajowości uczniowskiej w XVI-XVII wieku. Przegląd Historyczno-Oświatowy. R. 56: 2013 nr 3/4 s. 7084.

97. SAWICKA Beata: Erazm z Rotterdamu a humanistyczna edukacja Andrzeja Zebrzydowskiego w latach 1517-1530. Białostockie Teki Historyczne. T. 11: 2013 s. 35-50, sum.

98. SROKA Stanisław A[ndrzej]: Włoskie studia Turzonów w XVI wieku. Prace Komisji Środkowoeuropejskiej PAU. T. 21: 2013 s. 31-40, sum.

99. SULEJEWICZ-NOWICKA Monika: Jana Amosa Komeńskiego wykład o umiejętnym posługiwaniu się książkami jako najcenniejszym narzędziem kształtowania umysłu. Forum Bibliotek Medycznych. R. 5: 2012 nr 2 s. 49-62, sum.

Z 28 XI $1650 \mathrm{r}$. 


\section{Okres 1795-1918}

100. ADDENDA do dziejów oświaty. Z badań nad prasą XIX i początków XX wieku. Red. nauk. Iwonna Michalska i Grzegorz Michalski. Łódź 2013 Wydaw. Uniw. Łódzkiego ss. 233.

Treść: Michalska I., Michalski G.: Wstęp s. 7-9; Kita Jarosław: Problematyka oświatowa na łamach czasopism społeczno-ekonomicznych Królestwa Polskiego połowy XIX w. s. 13-22; Maciejewska Emilia: Edukacja ludności wiejskiej na łamach tygodników społeczno-kulturalnych Królestwa Polskiego po 1864 r. s. 23-30; Kuty Radosław: Prasa warszawska jako źródło do dziejów oświaty zakopiańskiej II połowy XIX i początków XX stulecia s. 31-45; Jamrożek Wiesław: Problematyka edukacyjna na łamach galicyjskiego „Naprzodu” s. 47-56; Pudłocki Tomasz: Dzienniki i tygodniki jako źródło badań nad oświatą. W poszukiwaniu alternatywnych spojrzeń na szkolnictwo średnie Galicji w dobie autonomii s. 57-63; Pachowicz Anna: Problemy oświaty i edukacji w 1882 r. w kontekście tarnowskiego pisma ekonomiczno-społecznego „Orzeł” s. 65-74; Szczepanik Wacław: Problemy oświatowe w dziewiętnastowiecznych austriackich szematyzmach wojskowych s. 75-92; Chrzanowski Tomasz: „Köningsberger Hartungsche Zeitung” jako źródło do dziejów wschodniopruskiego szkolnictwa średniego w II połowie XIX w. s. 93-102; Szulakiewicz Władysława: O zasłużonych redaktorach czasopisma „Muzeum” (1885-1939) s. 105-117; Świątek Adam: „Poległ wśród boju nauczycielskiego”. Wspomnienia pośmiertne na łamach czasopisma „Szkoła” jako źródło do historii nauczycielstwa galicyjskiego s. 119-130; Bołdyrew Aneta: „Oświata i moralność”. Prawnicy o roli oświaty w procesie modernizacji społeczeństwa polskiego na łamach czasopism prawniczych i społeczno-kulturalnych na przełomie XIX i XX w. s. 131-147; Skotniczna Ewa: Edukacyjna rola ilustracji w dziewiętnastowiecznej prasie dla dzieci i młodzieży s. 149-159; Dąbrowska Magdalena: O miłych i dla miłych. Tematyka kobieca w czasopismach rosyjskich przełomu XVIII i XIX w. s. 163-174; Walasek Stefania: Rodzina i jej obowiązki wobec najmłodszych na łamach prasy przełomu XIX i XX w. s. 175-186; Nawrot-Borowska Monika: Problematyka wychowania na łamach „Dwutygodnika dla Kobiet” (1880-1885) s. 187-212; Kalinowska-Witek Barbara: Wizerunek kobiety II połowy XIX i początku XX w. w świetle wybranych czasopism kobiecych i rodzinnych Królestwa Polskiego s. 213-233.

101. AUSZ Mariusz: Odbudowa Polskiej Prowincji Pijarów. Działalność wychowawczo-edukacyjna zakonu w latach 1873-1918. Lublin 2013 Wydaw. UMCS ss. 294, il., sum.

102. BEAUVOIS Daniel: Wilno - polska stolica kulturalna zaboru rosyjskiego 1803-1832. Dodruk. Wrocław 2012 Wydaw. Uniw. Wrocławskiego ss. 824, nlb. 2, tabl. 28, il. (Acta Universitatis Wratislaviensis; no 3203).

Rec.: Puchowski Kazimierz: Daniel Beauvois o szkolnictwie polskim na ziemiach litewsko-ruskich w latach 1803-1832. Wiek Oświecenia. [T.] 29: 2013 s. 341-353.

Wyd. 1. 2010.

103. BEDNARZAK-LIBERA Mirosława: Edukacja oraz jej wpływ na postawę działaczy galicyjskiego ruchu ludowego w świetle ich pamiętników i wspomnień. [W:] Z Chrystusem w służbie Bogu i ludziom. Księga Jubileuszowa z okazji 60. Rocznicy urodzin i 30-lecia pracy naukowej księdza profesora Romana Krawczyka. Red. Janusz Gmitruk, Anna Wielgosz. Siedlce-Warszawa 2012 s. $311-362$.

104. BEDNARZAK-LIBERA M.: Lwowskie koła Towarzystwa Szkoły Ludowej i ich działalność w latach 1891-1918. [W:] Znani i nieznani dziewiętnastowiecznego Lwowa. Studia i materiały. T. 3. Red. Lidia Michalska-Bracha i Małgorzata Przeniosło. Kielce 2013 s. 175-198.

105. BOGUS Marzena: Nauczyciele szkół ludowych Śląska Cieszyńskiego w XIX i na początku XX wieku: uwarunkowania prawne i zawodowe. Częstochowa-Czeski Cieszyn 2013 Wydaw. im. Stanisława Podobińskiego Akademii im. Jana Długosza; Kongres Polaków w Republice Czeskiej ss. 517, nlb. 1, il., shruntí, sum., Zsfg.

106. BOGUS M.: Prywatne szkoły elementarne na Śląsku Cieszyńskim pod koniec XIX i na początku XX w. Śląski Kwartalnik Historyczny Sobótka. R. 68: 2013 nr 1 s. 53-74, sum., Zsfg. 
107. CHRZANOWSKI Tomasz: „Stipendium Masovianum”w Królewskim Gimnazjum w Ełku w drugiej połowie XIX wieku (1858-1914). Komunikaty Mazursko-Warmińskie. R. 55: 2011 z. 2 s. 231-251, Zsfg., sum.

108. DZIENIS Helena: Akademia Handlowa w Gdańsku - Fundacja Jacoba Kabruna. Libri Gedanenses. T. 29/30: 2011/2012 [dr.:] 2013 s. 91-110, sum., Zsfg.

Lata $1832-1894$.

109. FALKOWSKA Joanna: Myśl wychowania narodowego w Galicji okresu autonomii. Twórcy i idee. Torun 2013 Adam Marszałek ss. 359, il., Zsfg. (Biblioteka Historii Edukacji; t. 3).

Rec.: Wałęga Agnieszka, Rozprawy z Dziejów Oświaty. T. 50: 2013 s. 220-224.

110. FALKOWSKA J.: O powinnościach nauczycielek szkół ludowych. Poglądy Anastazji z Jełowickich Dzieduszyckiej (1842-1890). Przeglad Historyczno-Oświatowy. R. 56: 2013 nr 3/4 s. $111-124$

111. GALEK Czesław: Niewłaściwe traktowanie nauczycieli przez uczniów w II połowie XIX wieku w świetle polskiej memuarystyki i beletrystyki. Przeglad Historyczno-Oświatowy. R. 56: 2013 nr 3/4 s. $125-139$.

112. GIBASIEWICZ Anna: Teofil Nowosielski [1812-1888], pisarz dla dzieci, orędownik sierot, na nowo odkrywany. Zeszyty Radomszczańskie. T. 7: 2013 s. 7-20.

113. GLIMOS-NADGÓRSKA Anna: Szkolnictwo Będzina 1795-1918 wraz z tekstami źródłowymi. Katowice 2012 Wydaw. UŚ ss. 399, nlb. 1. (Prace Naukowe Uniwersytetu Śląskiego w Katowicach; nr 2930).

Rec.: Stinia Maria, Studia Historyczneoryczne. R. 56: 2013 z. 2 s. 256-258.

114. GOŁĄB Maciej: Chopin und Elsner an der Hauptschule für Musik der Königlichen Universität zu Warschau (1826-1829). [W:] Józef Elsner (1769-1854). Życie, działalność, epoka. Red. Remigiusz Pośpiech. Opole 2013 s. 61-78.

115. HAUPTSTOCK Günter: Die Studenten - Ferienverbindung „Brassikaria” in Oberglogau. Portret. Rocznik Głogówecki. Nr 4: 2010 s. 115-122.

Powołane 11 X 1905 r.

116. HUSAR Czesław: Wkład Władysława Nowotarskiego [1866-1957] w rozwój szkolnictwa zawodowego w Żywcu na początku XX wieku. Gronie. Nr 12: 2012 s. 203-217.

117. IŻYKOWSKA Małgorzata: Polszczyzna uczniów tzw. szkół utrakwistycznych na Śląsku w połowie XIX wieku. Kwartalnik Opolski. R. 56: 2010 nr 2/3 s. 95-106, sum.

118. JURCZYSZYN Marek: Rola Mieczysława Brzezińskiego w rozwoju Polskiej Macierzy Szkolnej w latach 1905-1908. Przegląd Historyczno-Oświatowy. R. 56: 2013 nr 3/4 s. 140-154.

119. KAPUŚCIŃSKA Nina: Projekty ochronek dla dzieci wiejskich w świetle „Kroniki Rodzinnej”. Zeszyty Wiejskie. Z. 17: 2012 s. 284-296.

Lata 1873-1898 - czasopismo wydawane w Warszawie.

120. KARPIŃSKA Karolina: O nauczaniu geometrii w Gimnazjum Toruńskim w II połowie XIX wieku. Rozprawy z Dziejów Oświaty. T. 50: 2013 s. 113-148.

121. KLOSOWSKI Grzegorz: Absolewenci Królewskiego Progimnazjum w Kościerzynie w latach 1890-1915. Kościerskie Zeszyty Muzealne. [Z.] 7: 2013 s. 147-163. 
122. KOPERA Łukasz: Początek szkoły elementarnej w Maluszynie (1811 r.). Zeszyty Radomszczańskie. T. 7: 2013 s. 137-150.

123. KULIK Mariusz: Motywacje Polaków wstępujących do rosyjskich szkół wojskowych (1865-1914). [W:] Między irredentą a kolaboracją. Postawy społeczeństwa polskiego w latach niewoli - „W obcym mundurze”. Pod red. Lidii Michalskiej-Brachy i Marii Korybut-Marciniak. Warszawa 2013 s. $167-185$.

124. MASSALSKI Adam: Rola nauczycieli szkół średnich w budowaniu patriotyzmu młodzieży polskiej w XIX wieku. Przeglad Historyczno-Oświatowy. R. 56: $2013 \mathrm{nr}$ 3/4 s. 5-24.

125. MEISSNER Andrzej, Meissner-Łozińska Justyna: Szkice z dziejów myśli pedagogicznej w zaborze austriackim 1772-1918. Lublin 2013 Innovatio Press Wydaw. Nauk. Wyższej Szkoły Ekonomii i Innowacji ss. 242, il. Wyższa Szkoła Ekonomii i Innowacji w Lublinie. (Monografie Wydziału Pedagogiki i Psychologii Wyższej Szkoły Ekonomii i Innowacji w Lublinie).

126. MOKLAK Jarosław: Hałyczyna contra Galicja. Ukraińskie szkolnictwo średnie i wyższe w debatach Sejmu Krajowego galicyjskiego 1907-1914. Kraków 2013 Tow. Wydawnicze Historia Iagiellonica ss. 203, il., sum. (Studia z Historii XX Wieku; t. 15).

127. MROWIEC Ewa Małgorzata: „Towarzystwo Ewangelickie Oświaty Ludowej” w Cieszynie (1881-1905). Rocznik Teologiczny. R. 55: 2013 z. 1/2 s. 139-159, sum.

128. MUSIALIK Dominik: Postawy kierownictwa szkół średnich w Królestwie Polskim a problem rusyfikacji po klęsce powstania styczniowego w świetle wybranych pamiętników. Studenckie Zeszyty Historyczne. Z. 16: 2012 s. 39-47.

129. NAWROT-BOROWSKA Monika: Zabawy dzieci ziemiańskich w drugiej połowie XIX i na początku wieku XX w świetle pamiętnikarstwa. Biuletyn Historii Wychowania. [Nr] 29: 2013 s. $43-71$, sum.

130. NIEĆ Grzegorz, Wrona Grażyna: „Walka z lekturą zakazaną”. Bibliologiczne spojrzenie na dyskusje wokół książki „zakazanej” i jej wpływu na dzieci i młodzież w końcu XIX w. i na początku XX w. Toruńskie Studia Bibliologiczne. [T.] 6: 2013 nr 2 s. 135-152, sum.

131. OŚWIATA na ziemiach polskich pod zaborami wobec wyzwań cywilizacyjnych. Pod red. Andrzeja Meissnera i Jerzego Potocznego. Lublin 2013 Innovatio Press ss. 299, il. Wyższa Szkoła Ekonomii i Innowacji w Lublinie. (Monografie Wydziału Pedagogiki i Psychologii Wyższej Szkoły Ekonomii i Innowacji w Lublinie).

Treść: Meissner A., Potoczny J.: Wstęp s. 5-6; Meissner A.: Współczesna koncepcja historii wychowania i jej konsekwencje metodologiczne s. 7-15; Lubojemska Barbara: Wydawnictwa metodyczne do języka polskiego dla galicyjskich szkół ludowych doby autonomicznej s. 17-42; Dolata Elżbieta: Galicyjskie szkolnictwo przełomu XIX i XX wieku wobec sytuacji sanitarno-higienicznej uczącej się młodzieży s. 43-61; Meissner A.: Kształcenie nauczycieli szkół ludowych na ziemiach polskich w XIX wieku jako wyzwanie edukacyjne s. 63-80; Krawczyk Jerzy: Szkolnictwo zawodowe a rozwój gospodarczy ziem polskich w XIX i na początku XX wieku s. 81-127; Winiarz Adam: Szkoły zawodowe w planach industrializacji Królestwa Polskiego (1815-1831) s. 129-167; Galek Czesław: Koncepcje kształcenia zawodowego w Królestwie Polskim s. 169-187; Stinia Maria: Uniwersytet Jagielloński wobec potrzeb szkolnictwa średniego w Galicji w drugiej połowie XIX wieku s. 189-204; Szmyd Kazimierz: Uniwersytet Lwowski wobec narodowościowych i cywilizacyjnych problemów Galicji końca XIX wieku, do roku 1939 s. 205-221; Haratyk Anna: Społeczeństwo galicyjskie wobec wyzwań w dziedzinie opieki nad dziećmi i młodzieżą s. 223-239; Potoczny J.: Galicyjskie ugrupowania polityczne i towarzystwa oświatowe wobec analfabetyzmu środowisk plebejskich XIX i XX wieku s. 241-265; Rędziński Kazimierz: Życie kulturalno-społeczne Żydów w Galicji (1871-1914) jako przejaw dążeń emancypacyjnych s. 267-288; Szczerbiak Jerzy: Doktryna oświatowa ukraińskiego Kościoła greckokatolickiego w Galicji w latach $1850-1914$ s. $289-299$. 
132. PACHOLAK Marian: Pośród filomackich darów dla szkoły powiatowej w Kownie. [Cz. 1:] Edycje wrocławskie. Acta Universitatis Wratislaviensis. No 2779: Prace Liter. [T.] 45: 2005 s. $45-89$.

Toż. [Cz. 2]: Edycje warszawskie. Tamże. No 2998. [T.] 47 s. 21-54.

133. PAWLAK Tomasz: Prywatysta Witkiewicz. O maturze Stanisława Ignacego Witkiewicza. Pamiętnik Literacki. R. 104: 2013 z. 2 s. 205-218, sum.

We Lwowie w czerwcu 1903 r.

134. PEZALSKI Stanisław: Szkoły ludowe w Gminie Trzcinica w okresie zaboru pruskiego na podstawie kronik szkolnych. Trzcinica 2012 Gm. Trzcinica ss. 80, il. (Biblioteczka Gminy Trzcinica; 3 ).

135. PUGACEWICZ Iwona H.: O nieznanych początkach, pierwszych projektach i programie wychowawczym Szkoły Narodowej Polskiej w Paryżu. Przegląd Historyczno-Oświatowy. R. 56: $2013 \mathrm{nr} \mathrm{1/2} \mathrm{s.} \mathrm{89-107.}$

1 poł. XIX w.

136. RADZIK Anna: Dionizy Jaczewski i inni polscy studenci w Uniwersytecie Kazańskim w latach 40. XIX wieku. Annales Universitatis Paedagogicae. Cracoviensis. Folia 134: Studia Historyczne oricolitteraria. [T.] 13: 2013 s. 97-105, abstr.

137. RUTA Adam: „Szkolnictwo Ludowe” - pierwsze sądeckie czasopismo (1891-1913). [W:] Prasa sądecka od zarania do dziś 1891-2011. Pod red. Bolesława Farona; współpr. Agnieszka Ogonowska. Kraków 2012 s. 29-40.

138. SŁAWIŃSKI Piotr: Kształcenie młodzieży w Sandomierzu w latach 1815-1914. Kraków 2013 Libron - Filip Lohner ss. 296, nlb. 1, sum., rez.

139. SOSNOWSKA Joanna: Droga do niepodległości - działania instytucji opieki nad dziećmi w Łodzi w czasie I wojny światowej. Wybrane przykłady. [W:] Łódź w drodze do niepodległości. Pod red. Jolanty A. Daszyńskiej. Łódź 2013 s. 119-131.

140. SYGULSKI Marek: Płatnicy składki szkolnej, ludność, areał i zabudowa w gminie Mroga Dolna powiatu brzezińskiego w latach 1819-1893. Zeszyty Wiejskie. Z. 14: 2009 s. 111-139.

141. SZCZEPAŃSKI Jerzy, Wójcik Zbigniew: Oświatowe i gospodarcze koncepcje Stanisława Staszica a ewolucja szkolnictwa górniczo-hutniczego na ziemiach polskich do początku XX wieku. Studia Humanistyczne AGH. T. 11: 2012 [z.] 3 s. 183-196, sum.

142. SZULAKIEWICZ Władysława: O wyższości wychowania nad kształceniem. Wojciecha Dzieduszyckiego [1848-1909] rozważania pedagogiczne. Przeglad Historyczno-Oświatowy. R. 56: $2013 \mathrm{nr} \mathrm{3/4} \mathrm{s.} \mathrm{25-36.}$

143. ŚWIAT dziecka ziemiańskiego. Antologia źródeł. Wstęp, wybór i oprac. Nina Kapuścińska-Kmiecik, Jarosław Kita. Łódź 2013 Wydaw. Uniw. Łódzkiego ss. 219, il.

XIX w.

Rec.: Rybka Aleksandra, Rocznik Łódzki. T. 60: 2013 s. 286-288.

144. URBAŃSKA Magda: Wychowanie i kształcenie kobiet w XIX-wiecznej Polsce. Saeculum Christianum. R. 18: 2011 nr 1 s. 217-230, sum.

145. WAŁĘGA Agnieszka: Galicyjska „Szkoła” jako przykład czasopisma pedagogicznego okresu zaborów. Acta Universitatis Nicolai Copernici. Nauki Humanistyczno-Społeczne. Pedagogika. Z. 29: 2013 s. 9-28. 
146. WNĘK Jan: Książka, teatr oraz problematyka oświatowa na łamach dodatków do „Gazety Lwowskiej”. Rocznik Lwowski. 2010/2011 [dr.:] 2011 s. 111-120.

Lata $1817-1918$.

147. WNĘK J.: Polska recepcja niemieckiej myśli pedagogicznej w pierwszej połowie XIX wieku. Przeglad Zachodni. R. 69: 2013 nr 2 s. 191-204, abstr.

148. „WYSOKI Sejm raczy uchwalić...”. Starania o założenie Wyższej Szkoły Górnictwa i Hutnictwa w Krakowie w latach 1861-1914. Dokumenty. [Cz. 1]. Oprac. Anna Siwik, Regina Artymiak, Julian Kwiek. Kraków 2013 Wydaw. AGH ss. 368, il.

\section{Okres 1918-1939}

149. ADDENDA do dziejów oświaty. Z badań nad prasą Drugiej Rzeczypospolitej. Red. nauk. Iwonna Michalska i Grzegorz Michalski. Łódź 2013 Wydaw. Uniw. Łódzkiego ss. 348, il.

Treść: Michalska I., Michalski G.: Wstęp s. 7-9; Zakrzewska Aldona: Wychowanie obywatelskie w percepcji katolickiej doktryny wychowawczej Drugiej Rzeczypospolitej prezentowane na łamach „Miesięcznika Katechetycznego i Wychowawczego” (1918-1939) s. 13-30; Magiera Elżbieta: „Młody Spółdzielca” - czasopismo propagujące wychowanie spółdzielcze s. 31-52; Pawluk-Skrzypek Agnieszka: Problemy wychowania do sportu w dwudziestoleciu międzywojennym w świetle „Wychowania Fizycznego” (1920-1939) s. 53-66; Wolter Edyta: Zawartość treści rocznika „Ochrona Przyrody” (1920-1928): problematyka ekologiczno-wychowawcza s. 67-84; Jakubiak Krzysztof: Udział społeczno-kulturalnych i pedagogicznych wydawnictw periodycznych w wychowaniu i upowszechnianiu ideologii wychowawczej sanacji s. 85-89; Krasińska Izabela, Sławiński Piotr: Prasa abstynencka w Polsce (1918-1939) źródłem informacji na temat wychowania do życia w trzeźwości wśród dzieci i młodzieży s. 91-108; Durka Jarosław: Wartości edukacyjne w Miesięczniku Młodzieży Szkół Średnich Dąbrowy Górniczej „Młodzi Idą...” w dwudziestoleciu międzywojennym s. 109-125; Ryś Jan: Biografistyka na łamach wybranych czasopism wojskowych okresu II Rzeczypospolitej s. 127-134; Rogozińska Katarzyna: Oświata i szkolnictwo na łamach czasopism: „Przegląd Diecezjalny”, „Kielecki Przegląd Diecezjalny” w latach 1911-1939 s. 137-146; Michalski G.: Dyskusje o szkolnictwie polskim okresu międzywojennego na łamach jezuickiego „Przeglądu Powszechnego” w latach 1918-1939 s. 147-159; Lubczyńska Aleksandra: Nauczanie i wychowanie na łamach „Naszych Dróg” w latach 1927-1931 s. 161-173; Szczepańska Beata: Zagraniczne inspiracje dla kultury zdrowotnej szkoły polskiej na łamach czasopism medycznych i pedagogicznych w Drugiej Rzeczypospolitej Polskiej s. 175-193; Baranowicz Krystyna: Doskonalenie zawodowe nauczycieli na łamach „Szkoły Specjalnej” w okresie międzywojennym s. 195-204; Suska Agnieszka: Oświata dorosłych w świetle prasy samorządowej Drugiej Rzeczypospolitej s. 205-212; Ratajczak Krzysztof: Tematyka szkolnictwa i edukacji średniowiecznej w czasopiśmiennictwie naukowym II RP s. 213-222; Sosnowska Joanna: Problemy oświaty, wychowania i opieki nad dzieckiem na łamach „Dziennika Zarządu Miasta Łodzi” w latach 1919-1939 s. 225-246; Gumuła Teresa: Udział kobiet w edukacji i opiece na łamach tygodnika „Bluszcz” w latach 1918-1939 s. 247-261; Gołdyn Piotr: Zagadnienia pedagogiczne i oświatowe na łamach „Głosu Konińskiego” (1921-1939) s. 263-280; Wróblewska Urszula: Czasopisma tatarskie jako źródło do analizy oświaty Tatarów w latach 1918-1939 s. 281-295; Knyspel-Kopeć Renata: „Co wypada, a co nie”. Edukacyjna rola „Mojej Przyjaciółki” w zakresie nienagannego sposobu bycia kobiety s. 297-304; Kabzińska Łucja: Problematyka opieki społecznej na łamach czasopiśmiennictwa warszawskiego w latach 1923-1939 s. 305-324; Kabziński Krzysztof: Z zagadnień organizacyjno-prawnych opieki społecznej w Polsce (w świetle czasopiśmiennictwa okresu dwudziestolecia międzywojennego) s. 325-348

150. BAR-EL Adina: Jewish children's periodicals in Polen between the two world wars - in three languages. Rocznik Historii Prasy Polskiej. R. 16: 2013 z. 1 s. 5-48, streszcz.

151. CHAJKO Grzegorz: Sytuacja religijna i oświatowa ludności polskiej oraz ukraińskiej w powiecie Podhajce województwa tarnopolskiego w memoriale Towarzystwa Rozwoju Ziem 
Wschodnich z 1936 roku. [W:] Habent omnia tempora sua. Prace ofiarowane ks. prof. dr. hab. Januszowi Wyciśle. Red. Zdzisław Gogola. Kraków 2013 s. 105-117.

152. CHMIELEWSKA Agnieszka: Działalność organizacji paramilitarnych i młodzieżowych w Lubrańcu w latach 1918-1939 i ich wpływ na kształtowanie się świadomości politycznej i kulturalnej miasta. Zapiski Kujawsko-Dobrzyńskie. T. 28: 2013 s. 131-152, sum.

153. CIMAŁA Bogdan: Możliwość kształcenia się w języku polskim w rejencji opolskiej w okresie międzywojennym. [W:] Polityka państw narodowych wobec języka na Górnym Śląsku w XIX i XX wieku. Pod red. nauk. Michała Lisa, Łucji Jarczak, Leokadii Drożdż. Opole 2013 s. $19-32$.

154. DZIECI Operacji Polskiej mówią. 45 relacji. Wprowadzenie, rozdz. wstępny, oprac., red. Tomasz Sommer. Warszawa 2013 3S Media ss. 224, il. (Biblioteka Wolności).

Prowadzona od sierpnia 1937 r. do listopada 1939 r.

155. DZIENIAKOWSKA Jolanta: Organ Związku Inspektorów Szkolnych w Rzeczypospolitej Polskiej „Sprawy Szkolne”. Przegląd Historyczno-Oświatowy. R. 56: 2013 nr 1/2 s. 17-30.

156. GLIMOS-NADGÓRSKA Anna: Szkolnictwo zawodowe oraz dokształcające w województwie śląskim i w Zagłębiu Dąbrowskim w dwudziestoleciu międzywojennym. Prace Naukowe Uniwersytetu Ślaskiego w Katowicach. Nr 3064: Wieki Stare i Nowe. T. 5 (10): 2013 s. 114-136, sum., Zsfg.

157. GMURCZYK Zbigniew: Początki stowarzyszania się katolickiej młodzieży we Włocławku w pierwszych latach II Rzeczypospolitej (do 1925 r.). Zapiski Kujawsko-Dobrzyńskie. T. 28: 2013 s. $77-98$, sum.

158. GOŁDYN Piotr: Wyjątki z dziejów Państwowej Preparandy Nauczycielskiej w Uniejowie (1921-1926). Biuletyn Uniejowski. T. 2: 2013 s. 113-124, sum.

159. GRADKOWSKI Henryk: Krasiński w podręczniku Manfreda Kridla. Acta Universitatis Wratislaviensis. No 2998: Prace Liter. [T.] 47: 2007 s. 141-159.

Literatura polska wieku XIX. Cz. 3: Literatura na emigracji. Podręcznik dla szkół średnich. Wyd. 4. Warszawa 1931

160. HINZ Janusz: „Przyjaciel Młodzieży Terminującej”. Przyczynek do badań nad zapomnianym czasopismem, wydawanym w Grudziądzu w latach 1937-1939, dodatkiem do czasopisma „Rzemieślnik”. Rocznik Grudziądzki. T. 21: 2013 s. 247-253.

161. HUZARSKA Agnieszka: Początki turystyki w szkołach średnich Rzeszowa w latach 1918-1939. [W:] Studia i szkice w zakresie polskiej i zagranicznej teorii oraz historii kultury fizycznej. Pod red. Pawła Króla. Rzeszów 2012 s. 289-298.

162. JASTRZĘBSKI Jarosław: Funkcja prodziekana w państwowych szkołach akademickich II Rzeczypospolitej. Przeglad Historyczno-Oświatowy. R. 56: 2013 nr 1/2 s. 43-50.

163. JASTRZĘBSKI J.: Państwowe szkolnictwo akademickie II Rzeczypospolitej. Zagadnienia systemowe. Kraków 2013 Księg. Akademicka ss. 418, nlb. 3.

164. JASTRZĘBSKI J.: Studenci zwyczajni i wolni słuchacze w systemie szkolnictwa wyższego II Rzeczypospolitej. Prace Historyczne. [T.] 140: 2013 z. 4 s. 349-361, abstr. 
165. JASTRZĘBSKI J.: Uposażenie profesora zwyczajnego polskiej państwowej szkoły akademickiej od 1 II 1934 do 30 IX 1939 r. Roczniki Dziejów Społecznych i Gospodarczych. T. 73: 2013 s. 257-274, sum.

166. KOMOLKA Mirosława: Szkoły średnie w Lesznie w okresie międzywojennym. [W:] Śladami mistrza. Prace z historii najnowszej dedykowane profesorowi Antoniemu Czubińskiemu. Pod red. Stanisława Sierpowskiego. Poznań 2013 s. 79-92.

167. KOMOLKA M.: Udział nauczycieli Leszna w repolonizacji i dokształcaniu mieszkańców w okresie międzywojennym. Rocznik Leszczyński. T. 13: 2013 s. 107-136.

168. KOTOWSKI Robert: Dziewczęta w mundurkach. Młodzież żeńska szkół średnich w Polsce w latach 1918-1939. Kielce 2013 Muzeum Nar.; Fund. Posteris s. 3-398, il., sum.

169. KOTOWSKI R.: Książka, kino, teatr - rozrywki intelektualne młodzieży żeńskiej w międzywojennej Polsce. Rocznik Muzeum Narodowego w Kielcach. T. 28: 2013 s. 82-94, sum.

170. KOWALSKA Joanna Regina: Moda dziecięca czy ubrania dla dzieci? Charakterystyka ubiorów dziecięcych w okresie dwudziestolecia międzywojennego. Rozprawy Muzeum Narodowego w Krakowie. T. 6: 2013 s. 281-309, sum.

171. KRZYŻANOWSKI Lech: Rola Sejmu Śląskiego w zarządzaniu oświatą w województwie śląskim. Regulacje prawne oraz działalność praktyczna. [W:] Szkice z dziejów autonomii śląskiej w Drugiej Rzeczypospolitej. Red. nauk. Jarosław Durka. Katowice 2013 s. 66-85.

172. ŁĘGOWIK Renata: Częstochowskie czasopisma szkolne w latach międzywojennych. [W:] Książka i prasa w kulturze. Red. Katarzyna Domańska, Bernadeta Iwańska-Cieślik. Bydgoszcz 2013 s. 199-213.

173. ŁUKASZEWICZ Dariusz: Nauczyciele małych miast w propagowaniu postaw patriotycznych młodzieży w dwudziestoleciu międzywojennym. [W:] Małe miasta. Tradycje walk o niepodległość. Red. Mariusz Zemło. Supraśl-Lublin 2013 s. 351-367.

174. MAJCHRZYK-MIKUŁA Joanna: Higiena szkolna na Lubelszczyźnie w latach 1918 1939 na tle całego kraju. Piotrków Trybunalski 2013 Nauk. Wydaw. Piotrkowskie przy Filii Uniw. Jana Kochanowskiego ss. 509, nlb. 3, tabl. 10, il., sum.

Rec.: Urbanek Bożena, Medycyna Nowożytna. T. 19: 2013 z. 2 s. 245-250.

175. MARSZAŁ Maciej, Srokosz Jacek: Rzymianie czy barbarzyńcy? Z dyskusji nad reformą programu studiów prawniczych w Polsce w latach 1931-1937. Acta Universitatis Wratislaviensis. No 3264: Przegląd Prawa i Administracji. [T]. 83: 2010 s. 263-286.

176. MATEUSZ-RŻEWSKA Alicja, Matusz Bronisław, Matusz Olga: Między pamięcią a zapomnieniem. Z dziejów Zakładu Kształcenia Nauczycieli w Zgierzu. Zgierz 2013 Kolegium Nauczycielskie ss. 366, il.

XX-XXI w.

177. MAZAN Andrzej: Pedagogika Związku Sodalicji Mariańskich Uczniów Szkół Średnich w Polsce w latach 1919-1939. Łomianki-Milanówek 2013 Agencja Wydaw.-Handlowa „Bożena” ss. 200. (Biblioteka Maryjna Fundacji „Maximilianum”).

178. MĘDELSKA Jolanta: Kowieńskie wydanie Elementarza powiastkowego dla dzieci Mariana Falskiego. Język Polski. R. 89: 2009 z. 3 s. 199-207.

Rok 1936. 
179. MILEWSKA-MŁYNIK Anna: Kiedy nauka stawała się przyjemnością - o wakacyjnych ogniskach muzycznych w Krzemieńcu. Acta Universitatis Wratislaviensis. No 3538: Wrocławskie Studia Wschodnie. [T.] 16: 2012 s. 111-124, rez., sum.

Lata $1928-1939$.

180. NIEDOJADŁO Andrzej: Wychowanie narodowe i państwowe w szkołach powszechnych Okręgu Szkolnego Krakowskiego w latach 1918-1939. Lublin-Tarnów 2013 Tow. Nauk. KUL; Wydaw. Diec. Tarnowskiej Biblos ss. 341, nlb. 2, tabl. 16, il., sum.

181. NOWAK Zofia: Finansowanie Szkoły Domowej Pracy Kobiet w Kuźnicach przez „Zakłady Kórnickie” w latach 1925-1939. Do dr. przygot. Barbara Wysocka. Pamiętnik Biblioteki Kórnickiej. Z. 30: 2013 s. 155-176, sum.

182. OLCZAK-KARDAS Monika: Rola czasopism pedagogicznych dwudziestolecia międzywojennego w kształtowaniu świadomego odbiorcy książki i prasy (na wybranych przykładach). [W:] Książka i prasa w kulturze. Red. Katarzyna Domańska, Bernadeta Iwańska-Cieślik. Bydgoszcz 2013 s. $214-230$.

183. PERKOWSKA Bernadeta: „Pokłosie Szkolne”. Nasze Korzenie. Nr 2: 2012 s. 66-70.

Miesięcznik poświęcony szkołom powszechnym na Mazowszu Płockim, wyd. w Płocku w 1. 1927-1934.

184. PROCESY socjalizacji w Drugiej Rzeczypospolitej 1914-1939. Zbiór studiów. Pod red. Anny Landau-Czajki, Katarzyny Sierakowskiej. Warszawa 2013 IH PAN ss. 351, il. (Metamorfozy Społeczne; 7).

Z treści: Sierakowska K.: Wstęp s. 7-16; Sanojca Karol: Dwa patriotyzmy, czyli rzecz o wychowaniu polskiej i ukraińskiej młodzieży na Kresach Południowo-Wschodnich Drugiej Rzeczypospolitej s. 19-34; Stinia Maria: Między patriotyzmem a syjonizmem - wychowanie w gimnazjum żydowskim w Krakowie (1918-1939) s. 35-52; Landau-Czajka A.: Konstytucja „ad usum delphini” - o tym, jak thumaczono dzieciom konieczność zmiany konstytucji s. 53-65; Zieliński Konrad: Uwiedzeni, zmanipulowani, zdesperowani? Młodzież komunistyczna w Drugiej Rzeczypospolitej s. 67-92; Pudłocki Tomasz: Znaczenie szkoły jako czynnika wychowawczego w pismach nauczycieli szkół średnich obszarów południowo-wschodnich Drugiej Rzeczypospolitej s. 153-169; Piotrowska-Marchewa Monika: „Jacy będą przyszli obywatele”? Dzieci i młodzież Polski międzywojennej w relacjach pamiętnikarskich nauczycielek szkół powszechnych i średnich s. 171-189; Wiecki Evita: Kim mają być nasze dzieci? Podręczniki do nauki języka żydowskiego dla dzieci najmłodszych s. 193-213; Małek Agnieszka: Wychowawcze kształtowanie płci w poradnikach dla rodziców z okresu Drugiej Rzeczypospolitej s. 215-231; Stańczak-Wiślicz Katarzyna: Socjalizacja do roli nowoczesnej żony i matki na łamach pism kobiecych okresu dwudziestolecia międzywojennego s. 233-248.

185. PRZENIOSŁO Małgorzata: Rady opiekuńcze w województwie kieleckim 1918-1921. Kielce 2013 Wydaw. UJK ss. 252, nlb. 2, il.

186. PYTER Magdalena: Uregulowania prawne problematyki obowiązku szkolnego w polskim prawie oświatowym w latach 1918-1939. Studia Prawnicze KUL. [T.] 4: 2012 s. 107-120.

187. SAMSEL Agata: Podręczniki szkolne w latach międzywojennych jako narzędzie kształtowania postaw młodego pokolenia Polaków. [W:] Książka i prasa w kulturze. Red. Katarzyna Domańska, Bernadeta Iwańska-Cieślik. Bydgoszcz 2013 s. 152-168.

188. SANOJCA Karol: Relacje polsko-ukraińskie w szkolnictwie państwowym południowo -wschodnich województw Drugiej Rzeczypospolitej. Kraków-Wrocław 2013 Historia Iagellonica; Wydz. Nauk Hist. i Pedagog. Uniw. Wrocławskiego ss. 477, tabl. 8, il., sum. (Studia z Historii XX Wieku; t. 16).

189. SMOLARCZYK Andrzej: Prywatne szkolnictwo powszechne w województwie poleskim w latach 1919-1939. Rozprawy z Dziejów Oświaty. T. 50: 2013 s. 149-178. 
190. SOWIŃSKA Danuta: Edukacja i pierwsze doświadczenia zawodowe prawników siedleckich w okresie dwudziestolecia międzywojennego. Szkice Podlaskie. Z. 19/20: 2011/2012 [dr.:] 2013 s. 339-364.

191. SZLAWSKI Dariusz: Nauczyciele łódzcy w okresie międzywojennym. Kielce-Łódź 2013 Wydaw. Pedagog. ZNP; na zlec. Zarządu Okręgu Łódzkiego ZNP ss. 882, il.

192. ŚMIECIŃSKA Mariola: Prasa szkolna w Kaliszu w dwudziestoleciu międzywojennym.

Rocznik Kaliski. T. 39: 2013 s. 129-146.

193. TOMASZEWSKI Patryk: Ogólnopolski Związek Akademickich Kół Naukowych w latach 1929-1933 - zarys działalności. Analecta. R. 22: 2013 z. 1/2 s. 215-230, sum.

194. TYSZKIEWICZ Jan: Schronisko szkolne w Piaskach koło Szczawnicy. Prace Pienińskie. T. 23: 2013 s. $211-215$.

Lata $1926-1938$

195. URBAŃSKA Magda: Nauczycielki województwa śląskiego w czasie ustawy celibatowej (1926-1938). Saeculum Christianum. R. 18: 2011 nr 2 s. 169-178, sum.

196. WOCH Andrzej: Szkolnictwo średnie ogólnokształcące Lublina w latach 1918-1939. Przedm. Edward Walewander. Lublin 2013 Norbertinum ss. 197, nlb. 5, tabl. 17, il., sum. (Biblioteka Pedagogiczna Katedry Pedagogiki Porównawczej Wydziału Nauk Społecznych Katolickiego Uniwersytetu Lubelskiego. Ser. A: Studia; t. 25).

197. WOCH Katarzyna: Szkolnictwo powszechne na terenie gminy Jastków w okresie międzywojennym. [W:] Z przeszłości Jastkowa. Wybrane problemy lokalnej historii. Red. Cezary Taracha. Lublin 2013 s. 89-101.

198. WOLTER Edyta: Edukacja ekologiczna w Drugiej Rzeczypospolitej. Warszawa 2013 Wydaw. Uniw. Kardynała Stefana Wyszyńskiego ss. 586.

Rec.: Żółciński Zbigniew Jan, Przeglad Historyczno-Oświatowy. R. 56: 2013 nr 3/4 s. 202-205.

199. WOLTER Edyta: Ekologiczno-wychowawcze implikacje programów nauczania dla szkół powszechnych i średnich ogólnokształcących w Drugiej Rzeczypospolitej. Przegląd HistorycznoOświatowy. R. 56: 2013 nr 3/4 s. 85-97.

200. WÓJCIK Ewa: Podręczniki szkolne i opracowania dydaktyczne w repertuarze wydawców lwowskich dwudziestolecia międzywojennego. Annales Universitatis Paedagogicae Cracoviensis. Folia 146: Studia ad Bibliothecarum Scientiam Pertinentia. [T.] 11: 2013 s. 163-175, abstr.

201. WYWIAŁ Przemysław: Dom Żołnierza Polskiego w Krakowie. Z dziejów działalności kulturalno-oświatowej w armii II Rzeczpospolitej. Imponderabilia. Nr 4: 2012 s. 139-150, sum.

202. Z PRZESZŁOŚCI i współczesności kształcenia pedagogicznego w Cieszynie. Red. nauk. Robert Mrózek, Urszula Szuścik. Katowice 2013 Wydaw. UŚ ss. 220, sum., Zsfg. (Prace Naukowe Uniwersytetu Śląskiego w Katowicach; nr 3063).

Treść: Mrózek R., Szuścik U.: Słowo wstępne s. 7-8; Król Jan: Ruch nauczycielski na Śląsku Cieszyńskim s. 9-33; Bogus Marzena: Determinanty drogi zawodowej polskiego nauczyciela w czasach austriackich s. 35-52; Dawid Łucja: Wpływ „Miesięcznika Pedagogicznego" na kształtowanie się nowej formacji nauczycielskiej s. 53-68; Szuścik U.: Placówki edukacyjne w cieszyńskiej tradycji kształcenia nauczycieli s. 69-75; Zając Antoni: Rozwój polskiego szkolnictwa pedagogicznego w Cieszynie s. 77-87; Rusek Halina: W cieszyńskiej siedzibie Uniwersytetu Śląskiego s. 89-102; Olbrycht Katarzyna: Kształcenie pedagogów - animatorów społeczno-kulturalnych s. 103-112; Ogrodzka-Mazur Ewa, Szczurek-Boruta Alina: Z teorii i praktyki edukacji międzykulturowej s. 113-126; Uczyła-Zroski Jadwiga: Współudział przedmiotów pedagogicznych 
w kształtowaniu kompetencji zawodowych artystów i nauczycieli muzyki s. 127-141; Solik Ryszard: Nauczyciel - animator - edukator sztuki (z problematyki uniwersyteckiego kształcenia artystycznego) s. 143-152; Bortliczek Małgorzata, Łuc Izabela: Podyplomowe studia humanistyczne i dwuspecjalizacyjne studia polonistyczno-pedagogiczne w cieszyńskiej uczelni s. 153-162; Pindór Mirosława: W kręgu aktywności towarzystw i komisji naukowych w cieszyńskim środowisku uczelnianym s. 163-186; Tomaszewska Ewa: Teatr studencki przestrzenią spotkań mieszkańców Cieszyna s. 187-195; Grajewski Wojciech, Staroń Jakub: Zestawienie publikacji o historii kształcenia pedagogicznego na Śląsku Cieszyńskim s. 197-211.

203. ZAMECKA-ZALAS Olga: Działalność społeczna i oświatowa lekarek w II Rzeczypospolitej. Piotrków Trybunalski 2013 Nauk. Wydaw. Piotrkowskie przy Filii UJK ss. 184, nlb. 1, il. UJK w Kielcach. Filia w Piotrkowie Trybunalskim.

204. ZŁOTKIEWICZ-KŁĘBUKOWSKA Joanna: Polska obecność na uniwersytetach w Wielkiej Brytanii w okresie międzywojennym. Annales UMCS. Sec. F: Historia. Vol. 67: 2012 [nr] 2 s. 63-75, sum.

\section{Okres 1939-1945}

205. ALEKSANDER-SZCZELINOWA Janina: Tajne nauczanie w Muszynie w zakresie szkoły powszechnej w latach 1939-1945. Almanach Muszyny. [R. 23]: 2013 s. 283-290.

206. BOŁDYREW Aneta: Education and socialization of Polish children during World War II - sources, methods and the areas of activity of the historians of education. Piotrkowskie Zeszyty Historyczne. T. 14: 2013 s. 163-182, streszcz.

207. CHMIELEWSKI Witold: Działalność oświatowa urzędu ministra gen. broni Józefa Hallera (sierpień 1940-kwiecień 1941). Przegląd Historyczno-Oświatowy. R. 56: 2013 nr 3/4 s. $56-69$.

208. CHMIELEWSKI W.: Działalność wydawnicza polskich władz oświatowych na uchodźstwie w latach 1940-1945. Przegląd Historyczno-Oświatowy. R. 56: 2013 nr 1/2 s. 5-16.

209. CHROBACZYŃSKI Jacek: Tajna szkoła w okupowanym Krakowie 1939-1945. [W:] Polskie Państwo Podziemne w okupowanym Krakowie. Materiały sesji naukowej odbytej 14 kwietnia 2012 roku. Red. t. Marta Bochenek. Kraków 2013 s. 73-93.

210. DWORZACZKOWA Jolanta: Moje wspomnienia ze studiów historycznych w latach 1942-1947 i z początków pracy na Uniwersytecie Poznańskim. Poznań 2013 Inst. Historii UAM ss. 57, nlb. 2, il. (Studia i Materiały do Dziejów Instytutu Historii Uniwersytetu im. Adama Mickiewicza w Poznaniu; z. 1).

211. GROCHOWINA Sylwia: Niemieckie szkolnictwo średnie ogólnokształcące w Okręgu Rzeszy Gdańsk-Prusy Zachodnie w latach 1939-1945. Rozprawy z Dziejów Oświaty. T. 50: 2013 s. 99-112.

212. JABŁONOWSKA Agnieszka: Działalność wychowawcza Zgromadzenia Sióstr Wspólnoty Pracy od Niepokalanej Maryi w czasie okupacji niemieckiej (1939-1945). Studia Włoctawskie. T. 15: 2013 s. 236-244.

213. LEOŃCZYK Sergiusz: Polskie ośrodki opiekuńczo-wychowawcze w ZSRR i działalność Ambasady Polskiej w ZSRR podczas II wojny światowej. [W:] Stosunki polityczne, wojskowe i gospodarcze Rzeczypospolitej Polskiej i Związku Radzieckiego w latach II wojny światowej. 
Pod red. Janusza Gmitruka, Wojciecha Włodarkiewicza i Rafała Roguskiego. Warszawa-Siedlce 2013 s. $215-231$.

214. MIELNIK Tatiana: Opieka socjalna nad polskimi dziećmi w miejscach zesłania. Acta Universitatis Wratislaviensis. No 3538: Wrocławskie Studia Wschodnie. [T.] 16: 2012 s. 137-178, rez., sum.

W obwodzie archangielskim.

215. NOWICKA Olga: Gdy oświata była bronią. Wielkopolanie w walce o zachowanie polskiej nauki i kultury. [W:] Leć nasz orle w górnym pędzie. Pomnik Polskiego Państwa Podziemnego i Armii Krajowej w Poznaniu. Red. Aleksandra Pietrowicz; współpr. Włodzimierz Buczyński. Poznań 2013 s. 29-35.

216. PIETRZYKOWSKI Jan: Losy warszawskich salezjańskich zakładów młodzieżowych podczas okupacji hitlerowskiej. [W:] Lux ex Silesia. Księga pamiątkowa dedykowana księdzu profesorowi Józefowi Mandziukowi w 70. rocznicę urodzin. Red. Waldemar Gliński. Warszawa s. $579-594$.

217. PROTOKOŁY Powiatowej Komisji Weryfikacyjnej w Mińsku Mazowieckim do spraw legalizacji Tajnego Nauczania z 1945 roku. Rocznik Mińskomazowiecki. T. 21: 2013 s. 179-185.

218. RACHTAN Stefan: Szkolnictwo w Bodzentynie w okresie okupacji niemieckiej 1939-1945 (ze szczególnym uwzględnieniem tajnego nauczania). [W:] Z dziejów Bodzentyna $\mathrm{w}$ okresie II wojny światowej w 70. rocznicę pacyfikacji 1943-2013. Red. Lidia Michalska-Bracha, Marek Przeniosło, Marek Jedynak. Kielce-Bodzentyn 2013 s. 95-114.

219. SŁOMKA Zbigniew, Mulawa Marian: Dzieci Zamojszczyzny okresu okupacji niemieckiej w latach 1939-1944. Biłgoraj 2013 Zarząd Stow. Dzieci Zamojszczyzny ss. 260, il.

220. STAWIARSKI Bartłomiej: Obóz KLV w Łączanach koło Namysłowa. Przyczynek do nazistowskiego „Rozszerzonego Programu Wysyłki Dzieci na Wypoczynek” na Dolnym Śląsku w latach 1940-1944. Śląski Kwartalnik Historyczny Sobótka. R. 68: 2013 nr 3 s. 121-132.

221. WITEK-MALICKA Wanda: Dzieci z Auschwitz-Birkenau. Socjalizacja w obozie koncentracyjnym na przykładzie Dzieci Oświęcimia. Kraków 2013 Nomos ss. 316, nlb. 1, il., sum. Uniw. Śląski w Katowicach.

222. WOJTOWICZ Krystyna: Dzieciństwo w czasie wojny. Biuletyn Fundacji Gen. E. Zawackiej. Nr 58: 2010 s. 46-63.

Wspomnienia z Torunia.

223. ŹRÓDŁA do dziejów tajnego nauczania w regionie Kujaw wschodnich i ziemi dobrzyńskiej 1939-1945. [Wyd.] Bogdan Ziółkowski. Biuletyn Fundacji Gen. E. Zawackiej. Nr 59: 2010 s. 49-66.

\section{Okres 1945-1989}

224. APANEL Danuta, Wałęga Agnieszka, Gulczyńska Justyna: Sprawozdanie z Ogólnopolskiej Konferencji Naukowej pt. „Być nauczycielem w PRL-u...”, Gdańsk, 26-27 kwietnia 2012 roku. Biuletyn Historii Wychowania. [Nr] 29: 2013 s. 281-286. 
225. BACIŃSKI Grzegorz: Szkolna opozycja w latach osiemdziesiątych - rzecz nie tylko o Federacji Młodzieży Walczącej. [W:] Proch zamknięty w narodowej urnie. Historia najnowsza w badaniach doktorantów Instytutu Nauk Historycznych Uniwerystetu Kardynała Stefana Wyszyńskiego w Warszawie. Pod red. Małgorzaty Krupeckiej i Małgorzaty Żuławnik. WarszawaŁomianki 2012 s. 371-382.

226. BANAŚ Zdzisława: Wspomnienia. Kwartalnik Czudecki. R. 13: 2011 nr 2 s. 20-22.

Wspomnienia autorki (ur. w 1939) o latach dzieciństwa i szkolnych w Wyżnem oraz nauce w liceum w Czudcu.

227. BASIŃSKA Monika: Powojenne dzieje szkół podstawowych w Domiechowicach (1945-1981) i Woli Mikorskiej (1945-1967). [W:] Domiechowice, Ławy, Mikorzyce, Wola Mikorska. Pod red. Łukasza Politańskiego; wstępem opatrzył Marek Chrzanowski, Janusz Mękarski. Bełchatów 2012 s. $121-159$.

228. BERESZYŃSKI Zbigniew: Marzec '68 na Śląsku Opolskim - w cieniu studenckiego protestu. Studia Śląskie. T. 73: 2013 s. 107-134, sum., Zsfg.

229. BŁASZCZYK Agata: The future settlement and education of Poles in Great Britain after Second World War. The origins of the Interim Treasury Committee for the „Polish Question” and its Educational Branch. Przeglad Polsko-Polonijny. Nr 5/6: 2013 s. 225-236, streszcz.

230. BRASZCZYŃSKI Stanisław: „Złota kielnia”. Kutnowskie Zeszyty Regionalne. T. 17: 2013 s. $375-380$.

Młodzieżowy turniej szkół budowlanych, 1. 1971-1983.

231. BRYNKUS Józef: Komunistyczna ideologizacja a szkolna edukacja historyczna w Polsce (1944-1989). Kraków 2013 Wydaw. Antykwa ss. 503, nlb. 1, sum. Uniw. Pedagog. im. Komisji Edukacji Nar. w Krakowie.

232. BUCK Andrzej: Zielonogórskie czasopisma studenckie (1975-1980). [W:] Oblicza prasy Ziem Zachodnich w latach 1945-2012. Red. nauk. Andrzej Buck, Przemysław Bartkowiak, Dawid Kotlarek. Zielona Góra 2013 s. 128-151.

233. CHMIELEWSKI Witold Jan: Polska administracja szkolna w latach 1944-1950. Wyd. 2. Piotrków Trybunalski 2013 Nauk. Wydaw. Piotrkowskie ss. 591, tabl. 8, il., sum., Zsfg. UJK w Kielcach. Filia w Piotrkowie Trybunalskim.

Wyd. 1. 2010.

234. CONNELLY John: Zniewolony uniwersytet. Sowietyzacja szkolnictwa wyższego w Niemczech wschodnich, Czechach i Polsce 1945-1956. Przekł. Witold Rodkiewicz. Warszawa 2013 IHN im. Ludwika i Aleksandra Birkenmajerów PAN; Oficyna Wydawnicza Aspra-JR ss. XIV, 427. (Monografia z Dziejów Oświaty; t. 44).

235. DOROSZEWSKI Jerzy: Szkolnictwo i oświata na Lubelszczyźnie w latach 1944-1948. Lublin 2013 Innovatio Press ss. 207, il., sum. Wyższa Szkoła Ekonomii i Innowacji w Lublinie. (Monografie Wydziału Pedagogiki i Psychologii Wyższej Szkoły Ekonomii i Innowacji w Lublinie).

236. DWORACZEK Kamil: Studenci 1981. Strajk radomski. Wolność i Solidarność. Nr 4: 2012 s. $51-64$.

237. GAŁASZEWSKA-CHILCZUK Dorota: „Wrogie” uniwersytety. Polityka państwa komunistycznego wobec Katolickiego Uniwersytetu Lubelskiego i Uniwersytetu Marii CurieSkłodowskiej (1944-1969). Warszawa 2013 Warszawska Firma Wydawnicza ss. 292.

Rec.: Wrona Janusz, Res Historica. Nr 36: 2013 s. 349-354. 
238. GRUDZIŃSKI Andrzej: Działalność dydaktyczno-wychowawcza szkół katolickich archidiecezji krakowskiej w latach 1945-1956. Lublin 2013 TN KUL Jana Pawła II ss. 314, nlb. 5, il., sum. TN KUL Jana Pawła II. (Źródła i Monografie; 403).

239. GRZYBOWSKI Romuald: Polityczne priorytety i elementy codzienności socjalistycznej szkoły. Wybór studiów poświęconych dziedzictwu edukacyjnemu PRL-u. Toruń 2013 Adam Marszałek ss. 332.

240. GULCZYŃSKA Justyna: Przemiany w szkolnictwie średnim ogólnokształcącym w Polsce w latach 1944-1989. Poznań 2013 Wydaw. Nauk. UAM ss. 486, nlb. 2, sum. UAM. (Psychologia i Pedagogika; nr 194).

241. HLEBOWICZ Jan: Niepokorni z „Topolówki”. Działalność niezależna uczniów III Liceum Ogólnokształcącego im. Bohaterów Westerplatte w Gdańsku w latach 1970-1989. Gdańsk 2013 IPN-KŚZpNP. Oddz. ss. 143, nlb. 3, tabl. 19, il. (Publikacje Gdańskiego Oddziału IPN; t. 29).

242. JUŹWIK Aleksander: Organizacja opieki nad dziećmi i młodzieżą w latach 1944-1950 - od realizacji przedwojennych rozwiązań do przejęcia wzorców radzieckich. Polska 1944/45 -1989. [T.] 10: 2011 s. $135-154$, abstr.

243. JUŹWIK A.: Zagraniczna pomoc charytatywna dla dzieci i młodzieży w Polsce w latach 1945-1950. Polska 1944/45-1989. [T.] 11: 2013 s. 93-118, abstr.

244. KOŁAKOWSKI Andrzej: Działalność opiekuńcza Miejskiego Komitetu Opieki Społecznej w Gdańsku (1946-1949). Przegląd Historyczno-Oświatowy. R. 56: $2013 \mathrm{nr}$ 3/4 s. 167-181.

245. KONOPNICKA Janina: Szkoła i nauczyciel w środowisku raciborskim w latach 1945-1950. Racibórz 2013 Wydaw. Państ. Wyższej Szkoły Zawodowej ss. 239, il.

246. KROWICKI Stanisław Ludwik: „Żołnierz Ludu” wobec wydarzeń na polskich uczelniach w marcu 1968 roku. Przegląd Historyczno-Oświatowy. R. 56: 2013 nr 3/4 s. 155-166.

247. KRÓL Joanna: Idea „powrotu do macierzy” w teorii i praktyce edukacyjnej szkół średnich ogólnokształcących województwa szczecińskiego w okresie pionierskim. [W:] Nad Odrą i Bałtykiem. Myśl zachodnia. Ludzie, koncepcje, realizacja do 1989 r. Tom studiów pod red. Magdaleny Semczyszyn, Tomasza Sikorskiego i Adama Wątora. Szczecin 2013 s. 617-628.

248. KRÓL J.: Polski Październik 1956 roku w oświacie - trwanie czy zmiana? Przegląd Historyczno-Oświatowy. R. 56: $2013 \mathrm{nr}$ 1/2 s. 74-88.

249. KUBIAK Monika: Wspomnienie socrealizmu. Jak czasopisma zakładowe lat 50. miały kształtować umysły studentów i pracowników uczelni wyższych. [W:] Książka i prasa w kulturze. Red. Katarzyna Domańska, Bernadeta Iwańska-Cieślik. Bydgoszcz 2013 s. 231-239.

250. KUR Elżbieta M.: „Tygodnik Powszechny” wobec problemów edukacji polonistycznej w latach 1945-1989 (na tle polityki oświatowej). Siedlce 2013 Wydaw. Uniw. PrzyrodniczoHumanist. ss. 206. Uniw. Przyrodniczo-Humanist. w Siedlcach. (Rozprawa Naukowa; nr 123).

251. LESIAKOWSKI Krzysztof: Praca kulturalno-oświatowa w jednostkach Powszechnej Organizacji „Służba Polsce” (1948-1956) - założenia i realizacja. Zeszyty Wiejskie. Z. 16: 2011 s. 119-142, sum. 
252. NIEBEZPIECZNA wolność. „Uczeń Polski” (1979-1989). Fakty, wspomnienia, dokumenty. Pod red. Bartłomieja Noszczaka. Warszawa 2013 IPN-KŚZpNP ss. 295, nlb. 1, tabl. 64, il. IPN-KŚZpNP.

253. NOSZCZAK Bartłomiej: Solidarność nastolatków. Przyczynek do historii Międzyszkolnego Komitetu Solidarności (1987/1988-1990). Zeszyty Historyczne WiN-u. R. 22: 2013 nr 37 s. 59-74, sum.

254. NOWAK Danuta: Obraz edukacji historycznej na Ziemiach Zachodnich na łamach czasopisma „Nadodrze” (1957-1959). [W:] Oblicza prasy Ziem Zachodnich w latach 1945-2012. Red. nauk. Andrzej Buck, Przemysław Bartkowiak, Dawid Kotlarek. Zielona Góra 2013 s. 218-231.

255. NOWAK D.: Przemiany edukacyjne na wsi lubuskiej po 1945 roku na łamach czasopisma „Nadodrze” (1957-1959). [W:] Ruch ludowy na Ziemi Lubuskiej 1945-201. Red. Edward Jaworski. Gorzów Wlkp. 2013 s. 139-154.

256. NOWAK Rafał Kazimierz: Zarys działalności Wydziału Kulturalno-Oświatowego Zarządu Obwodowego Związku Patriotów Polskich we Lwowie w latach 1944-1946. Acta Universitatis Lodziensis. Folia Historica. Folia Historica. [Vol.] 91: 2013 s. 51-72, sum.

257. OLSZEWSKA Bożena: Techniki ideologicznej indoktrynacji w wybranych utworach realizmu socjalistycznego publikowanych w „Płomyczku”. Kwartalnik Opolski. R. 54: 2008 nr 2/3 s. $113-124$, Zsfg.

258. OSIŃSKI Zbigniew: Działania aparatu bezpieczeństwa wobec oświaty na Lubelszczyźnie w latach 1944-1989. Lublin 2013 Wydaw. UMCS ss. 290.

Rec.: Charczuk Wiesław, Rozprawy z Dziejów Oświaty. T. 50: 2013 s. 197-206; Charczuk W., Stupskie Studia Historyczne. Nr 19: 2013 s. 293-300; Charczuk W.: Oświata na Lubelszczyźnie a działania aparatu represji PRL. Studia Historyczne. R. 56: 2013 z. 2 s. 227-235.

259. PABIS Anna: Ciernista droga. Wyd. 2. uzup. Libusza 2013 Tadeusz Pabis ss. 228, il. Wyd. 1. Gorlice 1995.

Wspomnienia autorki (ur. 1933) o życiu codziennym w Libuszy, nauce w Szkole Rolniczej w Kobylance (1948-1950), pracy w „Służbie Polsce”.

260. PACIOREK Magdalena: Dyscyplina pracy i nauki na przykładzie studentów polskich wydziałów lekarskich na przełomie lat 40. i 50. Medycyna Nowożytna. T. 19: 2013 z. 2 s. 169-193, sum.

261. POPIŃSKI Krzysztof: Rola edukacji na poziomie wyższym w modernizacji społeczno-ekonomicznej Polski w latach 1945-1989. [W:] Modernizacja czy pozorna modernizacja. Społeczno-ekonomiczny bilans PRL 1944-1989. Praca pod red. Jerzego Chumińskiego. Wrocław 2010 s. $232-294$.

262. PRZYBYSZ Mateusz: Wojna polsko-bolszewicka w nauczaniu historii w szkołach podstawowych i średnich w latach 1944-1989. Przegląd Wschodnioeuropejski. [T.] 2: 2011 s. 77-91, sum.

263. PYKA Kazimiera Maria: Śląskie wspomnienia. Koszęcin 2013 Stow. Inicjatyw Społ. ss. 95 , nlb. 1 , il.

Wspomnienia autorki (ur. 1935) o życiu codziennym i oświacie w Cieszowej i Koszęcinie.

264. SKONIECZNY Tomasz: Rozwój szkolnictwa podstawowego w gminie Będzino w latach 1945-1954. Biuletyn Historii Wychowania. [Nr] 29: 2013 s. 117-134, sum. 
265. SYCHOWICZ Krzysztof: Społeczeństwo regionu łomżyńskiego wobec usuwania krzyży ze szkół w 1958 r. Studia Łomżyńskie. T. 22: 2012 s. 155-170.

266. SZCZEPAŃSKI Andrzej: Oświata żydowska w powojennej Legnicy (1945-1968). Biuletyn Historii Wychowania. [Nr] 29: 2013 s. 101-115, sum.

267. TALAREK Kazimierz: Duchowieństwo i świeccy diecezji tarnowskiej wobec Okólnika Ministerstwa Oświaty w sprawie przestrzegania świeckości szkoły (nr 26 z 4 sierpnia 1958 roku) w świetle doniesień Służby Bezpieczeństwa. [W:] Dzieje diecezji tarnowskiej. T. 2: Instytucje i wydarzenia. Red. Anna Gąsior, Janusz Królikowski. Tarnów 2012 s. 627-652.

268. TECHMAŃSKA Barbara: Młodzi zbuntowani - młodzież Zagłębia Miedziowego przeciwko realiom stanu wojennego. Studia Śląskie. T. 71: 2012 s. 111-127, sum., Zsfg.

269. TECHMAŃSKA B.: Punkty nauczania języka ukraińskiego w Zagłębiu Miedziowym. Studia Śląskie. T. 72: 2013 s. 161-174, sum., Zsfg.

270. ULJASZ Adrian: Zespoły dobrego czytania i koła planowego czytania na terenie Okręgu Szkolnego Lubelskiego w latach 1945-1948. Rocznik Bibliologiczno-Prasoznawczy. [R.] 4(15): 2012 z. 1 s. $105-126$, sum.

271. WITKOWSKI Sławomir: Kultura fizyczna w sosnowieckich szkołach fryzjerskich i odzieżowych w latach 1945-1948. [W:] Z dziejów kultury fizycznej w Sosnowcu. Pod red. Mirosława Ponczka, Sławomira Witkowskiego i Adama Fryca. Katowice-Sosnowiec 2012 s. 119-123.

272. WALUŚ Mirosław: Trzydziestoletnia historia krzyży w szkołach w Krobi, w parafii pod wezwaniem św. Mikołaja. Krobia 2013 MProjekt Mikołaj Andrzejewski ss. 61, il.

Lata 80. XX w.

273. WOJCIESZYK Elżbieta: Duszpasterstwo młodzieży Archidiecezji Poznańskiej w latach 1945-1989. Wyd. 2, popr. i uzup. Poznań 2013 Inst. Studiów Kościelnych Lubranscianum ss. 372, il. (Studia i Materiały; t. 3).

Wyd. 1. 2012.

274. ZAANGAŻOWANIE? opór? gra? Szkic do portretu nauczyciela w latach PRL-u. Pod red. nauk. Romualda Grzybowskiego. Toruń 2013 Adam Marszałek ss. 635, il. (Szkoła, Państwo, Społeczeństwo; t. 4).

Treść: Grzybowski R.: Wstęp s. 9-13; Śliwerski Bogusław: Nauczyciel PRL w garderobie marksistowskiej pedagogiki s. 17-30; Rutkowiak Joanna: Etos zawodowy nauczycieli czasów PRL; temporalny aspekt zjawiska s. 31-40; Grzybowski R.: Nieufność jako dominująca cecha relacji pomiędzy nauczycielami a władzami komunistycznymi w latach PRL-u s. 41-58; Wojniak Justyna: „W służbie socjalizmu, patriotyzmu i internacjonalizmu". Rola nauczyciela w świetle założeń polityki oświatowej PRL lat 70. i 80. s. 59-69; Król Joanna: Wizerunek nauczyciela w ideologii Związku Młodzieży Polskiej - założenia a rzeczywistość s. 70-82; Gorloff Elżbieta: Nauczyciele w przestrzeni działań KW PPR w Gdańsku s. 83-94; Durka Jarosław: Wydział Nauki, Oświaty i Kultury KW PZPR w Częstochowie wobec nauczycieli w latach 1975-1989 s. 95-107; Ryś Jan: Wpływ nadzoru pedagogicznego na rozwój zawodowy nauczycieli w okresie PRL-u s. 108-124; Jakubiak Krzysztof: Tradycje, kierunki i dziedziny badań pedeutologicznych w II Rzeczypospolitej i w Polskiej Rzeczypospolitej Ludowej s. 125-133; Gulda Mieczysław: Nauczyciel niepokorny w PRL-owskiej szkole. Socjologiczna analiza przypadku s. 137-149; Wojcik Teresa G.: Nauczyciel w PRL-u jako uczestnik skomplikowanej gry s. 150-159; Dylak Stanisław, Leszkowicz Mateusz, Szewior Marta, Garbatowska Agnieszka: Nauczyciel PRL a III RP - między zaangażowaniem a angażem s. 160-174; Gulczyńska Justyna, Jamrożek Wiesław: Opozycyjna działalność nauczycieli w Polsce w latach osiemdziesiątych (wprowadzenie do problemu) s. 175-190; Osiński Zbigniew: Nauczyciele Lubelszczyzny wobec NSZZ „Solidarność” s. 191-206; Puliński Andrzej: Szykany i represje wobec nauczycieli na Warmii i Mazurach w latach 1945-1956 s. 207-218; Czekaj Małgorzata: Katecheta i katecheza w Polsce Ludowej. Sekularyzacyjne uwikłanie s. 219-228; 
Wróblewska Urszula: Codzienność szkolna na Żuławach po 1945 roku - w świetle wspomnień nauczycieli i dokumentów szkolnych s. 229-240; Paszkowska Anna: Nauczyciele wiejscy województwa gdańskiego jako uczestnicy kolektywizacji wsi (1948-1956) s. 241-257; Massalski Adam: Nauczyciele Liceum im. Stefana Żeromskiego w Kielcach w latach stalinowskich s. 261-270; Winiarz Adam: Jedno nauczycielskie życie na tle polityki oświatowej Polski Ludowej s. 271-283; Grzybowska Danuta: Nauczyciel PRL-u w doświadczeniu ucznia klas I-IV s. 284-295; Spiss Anna, Ślęczka Ryszard: Studium do zbiorowego portretu nauczycieli szkół krakowskich: Bohdan Pytliński (1907-1963) s. 296-309; Śpica Paweł: Jerzy Suczyński (1929-1996) - nauczyciel, historyk, opozycjonista. Szkic do portretu s. 310-323; Aleksander Zdzisław: O przygotowaniu do zawodu i pełnieniu roli nauczyciela w PRL w świetle własnej biografii s. 324-328; Żerko Józef: Edukacyjny „,tor przeszkód" nauczycielskiej profesji. Refleksja osobista s. 329-335; Chmielewski Witold: Kształcenie polskich kadr oświatowych na uchodźstwie w latach 1941-1948 s. 339-350; Apanel Danuta: Zakłady kształcenia nauczycieli na Pomorzu Środkowym w okresie Polski Ludowej (1945-1975) s. 351-362; Suchowiecka Anita: Kształcenie i dokształcanie nauczycieli szkół zawodowych w okresie funkcjonowania Centralnego Urzędu Szkolenia Zawodowego (1949-1956) s. 363-376; Szarkowska Agnieszka: Wyższa Szkoła Nauczycielska w Białymstoku jako przykład zakładu kształcenia nauczycieli s. 377-386; Maźwa Wioletta: Funkcje i zadania powojennych zakładów kształcących nauczycieli średnich szkół medycznych s. 387-397; Kahl Edyta: Doskonalenie nauczycieli w Polsce Ludowej lat 60. w perspektywie urzeczywistniania koncepcji jednolitego frontu wychowawczego s. 398-413; Pulińska Urszula: Doskonalenie zawodowe nauczycieli w Olsztyńskiem w latach 1945-1950 s. 414-426; Michalski Andrzej: Kadra naukowa i artystyczna wyższych szkół muzycznych w Polsce w latach 1945-1962 s. 427-440; Dormus Katarzyna: Wizerunek nauczyciela na łamach „Ruchu Pedagogicznego” i „Nowej Szkoły” w latach 1945-1956 s. 443-454; Magiera Elżbieta: Dwumiesięcznik „Spółdzielczość w Szkole” jako pismo kształtujące postawy nauczycieli w latach 70. XX wieku s. 455-473; Gumuła Teresa: Rola społeczno-zawodowa nauczycieli na łamach wybranych czasopism pedagogicznych w latach 1945-1948 s. 474-491; Wałęga Agnieszka: Zagadnienia pedeutologiczne na łamach „Kwartalnika Pedagogicznego" (1956-1989) s. 492-502; Kołakowski Andrzej: Od opiekuna do nauczyciela - ewolucja zawodu wychowawcy domu dziecka w świetle peerelowskiego czasopiśmiennictwa pedagogicznego s. 503-511; Gołdyn Piotr: Nauczyciel - wychowanie - szkoła na łamach „Tygodnika Solidarność” (1981 r.) s. 512-524; Grabowska Dorota: Obraz nauczyciela okresu PRL w literaturze pamiętnikarskiej s. 525-534; OssowskaZwierzchowska Aldona: Wizerunek nauczyciela w polskim filmie fabularnym w latach 1945-1989 s. 535-544; Kełpin Agata: Udział Towarzystwa Szkoły Świeckiej i czasopisma „Wychowanie” w procesie ideologicznego urabiania nauczycieli w latach rządów Władysława Gomułki s. 545-557; Koźmian Danuta: Nauczyciele Pomorza Zachodniego i ich funkcje społeczno-oświatowe w latach powojennych s. 561-567; Radziszewska Maria: Życie prywatne nauczycieli w powojennym Olsztyńskiem w świetle wspomnień i pamiętników s. 568581; Techmańska Barbara: Rola nauczyciela pioniera w budowaniu polskiej szkoły na Ziemiach Odzyskanych w świetle wspomnień i pamiętników s. 582-596.

\section{Okres 1989-2013}

275. ANDREJUK Katarzyna: Europeizacja w diasporze. Studenci polscy na uczelniach w Londynie po 2004 roku. Warszawa 2013 Wydaw. IFiS PAN ss. 311, nlb. 1.

276. BARON Piotr: Osiemnaście lat nauczania języka niemieckiego jako języka mniejszości narodowej w Polsce ze szczególnym uwzględnieniem województwa opolskiego. Rocznik Eubowicki. [T.] 6: 2008 s. 113-125, Zsfg., res.

277. BURZYŃSKA-WENTLAND Lidia: Szkolnictwo oraz działalność kulturalno-oświatowa w zakresie podtrzymywania tożsamości narodowej, religijnej i językowej mniejszości narodowych i etnicznych w województwie gdańskim (pomorskim) w latach: 1989-2007. Gdańsk 2013 Wydaw. Uniw. Gdańskiego ss. 554, nlb. 1. 
278. DRAUS Jan: Konferencja Rektorów Publicznych Szkół Zawodowych w Polsce 1998-2013. 15 lat KRePSZ. Gniezno [i in.] 2013 Państ. Wyższa Szkoła Zawodowa; na zlec. Konferencji Rektorów Publ. Szkół Zawodowych ss. 160, il.

279. GASS Izabela: Kształcenie archiwistów na poziomie średnim. Archiwista Polski. R. 18: 2013 nr 1 s. $51-55$.

Od $2005 \mathrm{r}$.

280. JARKIEWICZ Katarzyna: Informator o redakcjach gazet akademickich w 2012 roku. Forum Bibliotek Medycznych. R. 5: 2012 nr 1 s. 547-590, sum.

281. MEZGLEWSKI Artur: Aspekty prawne nauczania religii w szkołach publicznych. Premislia Christiana. T. 14: 2010/2011 [dr.:] 2011 s. 35-52.

282. ORAWCZAK Danuta: 5-lecie Towarzystwa Oświatowego Ziemi Dzierżoniowskiej. Rocznik Dzierżoniowski. T. 19: 2009 [dr.:] 2010 s. 182-184.

Powstało 3 XII 2004 r.

283. PASTUSZKA Stefan Józef, Turkowski Romuald: Pokusowe ziarno. Fundacja im. Zofii i Władysława Pokusów Wspierania Edukacji Młodzieży Wiejskiej. Słowo wstępne Stefan Rachwalski. Kraków-Warszawa 2013 Fund. im. Zofii i Władysława Pokusów Wspierania Edukacji Młodzieży Wiejskiej; Lud. Tow. Nauk.-Kult. ss. 181, nlb. 3, tabl. 72, il.

Władysław Pokusa (1912-2003), Zofia Pokusa (1914-2007). Fundacja założona w 1999 r.

Rec.: Pękul Grzegorz, Parzych Arkadiusz, Rocznik Historyczny Muzeum Historii Polskiego Ruchu Ludowego. Nr 29: 2013 s. 313-318.

284. PELKA Daniela: Dwadzieścia lat nauki języka niemieckiego na Górnym Śląsku - stan i perspektywy. Rocznik Łubowicki. [T.] 8: 2010 s. 197-218, Zsfg., res.

285. SAJNA Marian: Oświata Bydgoszczy po 1989 roku - rola i działania władz samorządowych oraz szkolnych organów społecznych. [W:] Bydgoszcz. Współczesne oblicze miasta. Pod red. Alberta S. Kotowskiego i Sławomira Sadowskiego. Bydgoszcz 2012 s. 105-113.

286. STEFANIAK Piotr: Znak wiary. Szkoły Braci Szkół Chrześcijańskich w Gdańsku (1992-2012). Gdańsk-Kraków 2012 Wydaw. Inst. Teol. Księży Misjonarzy ss. 124, tabl. 128, il.

287. ULJASZ Adrian: Prasa popularnonaukowa we współczesnej Polsce a edukacja humanistyczna i kulturalna młodzieży. Czasopismo „Cogito”. Rocznik Bibliologiczno-Prasoznawczy. [R.] 4(15): 2012 z. 2 s. $141-155$, sum.

288. WRZEŚNIEWSKI Wincenty: Szkolnictwo rolnicze w Wielkopolsce w latach 1989-2004 Poznań 2013 Wydaw. Uniw. Przyrodniczego ss. 462, il., sum. Uniw. Przyrodniczy w Poznaniu. (Rozprawy Naukowe; 457).

\section{Oświata polonijna}

289. ANDRAKA Dorota: Sytuacja szkolnictwa polonijnego na wschodnim wybrzeżu USA w ostatnim dziesięcioleciu. [W:] 70 lat współczesnej polszczyzny. Zjawiska, procesy, tendencje. Księga jubileuszowa dedykowana profesorowi Janowi Mazurowi. Pod red. Anny DuninDudkowskiej, Agaty Małyski. Lublin 2013 s. 729-733. 
290. CHMIELEWSKI Witold Jan: Przygotowanie kadr oświatowych na uchodźstwie w latach 1941-1948. Warszawa 2013 IHN PAN; ASPRA-JR ss. 216, il., sum., Zsfg. Inst. Hist. Nauki im. Ludwika i Aleksandra Birkenmajerów PAN. (Monografie z Dziejów Oświaty; t. 43).

291. KANIEWSKI Przemysław: Polska Szkoła Architektury w Wielkiej Brytanii 1942-1954. Warszawa 2013 Marek Woch ss. 236, il., sum.

Przy Uniwersytecie w Liverpool.

292. NEY-KRWAWICZ Marek: Żołnierze AK w polskich szkołach na obczyźnie 1945-1948. Przyczynek do losów pokolenia. Biuletyn Informacyjny Studium Polski Podziemnej. Nr 4: 2010 s. 32-35.

293. PYŁAT Joanna: Dorobek wydawniczy Polskiego Uniwersytetu na Obczyźnie. Rocznik Bibliologiczno-Prasoznawczy. [R.] 4(15): 2012 z. 1 s. 79-91, sum.

Lata 1952-2008

294. PYŁAT J.: Sprawozdanie z międzynarodowej konferencji naukowej PUNO: „Szkolnictwo polskie w Europie Zachodniej i Środkowo-Wschodniej”. Rocznik Polskiego Towarzystwa Naukowego na Obczyźnie. R. 55: 2011/2012 [dr.:] 2013 s. 276-281.

Londyn, 13 IV 2013 r.

295. PYŁAT J. Krystyna: PUNO Polski Uniwersytet na Obczyźnie. Londyn-Pułtusk 2010 Akad. Humanist. im. Aleksandra Gieysztora ss. 275, nlb. 13, il. Akad. Humanist. im. Aleksandra Gieysztora.

XX-XXI w.

296. SZCZERBIŃSKI Marek, Wasilewski Krzysztof: Stan badań nad dziejami harcerstwa poza granicami Polski. [W:] Studia i szkice w zakresie polskiej i zagranicznej teorii oraz historii kultury fizycznej. Pod red. Pawła Króla. Rzeszów 2012 s. 469-480.

297. WIENCZENOWICZ TAHIS Janina: Mali Polacy. Codzienność polskich dzieci w Brazylii (1920-1960). Warszawa 2013 MHPRL; Inst. Studiów Iberyjskich i Iberoamerykańskich ss. 116, nlb. 4, il. (Biblioteka Iberyjska).

\section{DZIEJE SZKÓŁ RÓŻNYCH STOPNI}

1. Szkoły podstawowe i zakłady wychowawcze

298. BARĆ Małgorzata: 60 lat Przedszkola w Czudcu. Kwartalnik Czudecki. R. 11: 2009 nr 2 s. $8-9$.

299. CHABRZYK Anna, Stopka Janusz: Historia Szkoły Podstawowej nr 4 w Nowym Targu. Almanach Nowotarski. Nr 16: 2012 s. 33-40.

Od roku szk. 1933/34.

300. CHMIELNIAK Agata: Nasza historia 1963-2013. Szkoła Podstawowa nr 6, Zespół Szkół nr 3, Gimnazjum Publiczne nr 3. Porąbka 2013 DTL ss. 108, il. 
301. CIEŚLAK Beata: Szkoła pod szczęśliwą gwiazdą... 55 lat sosnowieckiej „Dwudziestki”. Współpr. Anna Szymańska, Barbara Łudzień, Wiesław Budzikur. Sosnowiec 2013 Szkoła Podst. nr 20 im. Mikołaja Kopernika ss. 215, nlb. 1, il. + 1 dysk optyczny (CD-ROM).

$2 \mathrm{w} 3$

302. DALL Lesław: Szkoła na Olczy 1861-2011. Zakopane 2011 Gm. M. Zakopane ss. 144, il.

Szkoła Podstawowa Nr 4 im. Marszałka Józefa Piłsudskiego w Zakopanem.

303. DOLAT Krystyna: Działalność Szkolnego Koła Krajoznawczo-Turystycznego przy Państwowym Domu Dziecka w Malinie k/Kutna w latach 1962-1977. Kutnowskie Zeszyty Regionalne. T. 17: 2013 s. 331-374.

304. DOMAŃSKA Joanna M.: Organizacja procesu opiekuńczo-wychowawczego w domach dziecka w latach 1945-1989 na Warmii i Mazurach. Studia Warmińskie. T. 50: 2013 s. 111-138, sum., Zsfg.

305. DYKER Anna: Działalność Szkoły Podstawowej Nr 1 w Wałczu w pierwszych latach po II wojnie światowej. Studia i Materiaty do Dziejów Ziemi Wateckiej. Nr 4: 2013 s. 99-108.

306. DZIADKOWE Ognisko Praga 1933-1971. Oprac. Kazimierz Dąbrowski. Warszawa 2013 Elipsa ss. 167, il.

Treść: Godło i barwy TPDzUl s. 5-6; Kazimierz Lisiecki „Dziadek” [1902-1976] s. 7-12; Ognisko TPDzUl/PZOW 1928-1971 s. 14; Nasz Dom - Środkowa 9 s. 15-22; Słownik wyrazów ogniskowych s. 23-24; Wśród Felusiów i Mamutów s. 25-27; Hotelik s. 28-29; Przy stole i na dyżurze s. 30-32; Oczko [gazetka ścienna] s. 33; Fair play czyli sportowcy amatorzy s. 34-38; Zgodnym chórem bracia s. 39-46; 83 WDH [Warszawska Drużyna Harcerska] s. 47-49; Ogniskowe święta s. 50-55; Życie codzienne s. 56-57; Nasi goście i przyjaciele s. 58-60; Wspomnienia Prażan s. 61-70; Ogniskowcy - Prażanie s. 71-140; Ciocie, Wujenki, Stryjkowie w Ognisku Praga s. 141-153; Żywe tradycje s. 154-166.

Dom dziecka w Warszawie.

307. DZIENNIK Zakładu Sierot w Łące w latach 1935-1939. [Wyd.] Małgorzata Gaweł. Saeculum Christianum. R. 19: 2012 nr 2 s. 91-309.

308. [DZIEWIĘĆDZIESIĘCIOLECIE] 90-lecie szkolnictwa w Kaznowie. 50 lat szkoły podstawowej im. Jana Sławińskiego 1963-2013. Wydanie jubileuszowe. Zespół red. Marzanna Matyjaszczyk [i in.]. Kaznów 2013 Drukarnia Standruk ss. 239, il.

309. GALEJA Justyna: Ponad 100 lat służby dla społeczności rudzkiej. Rudzki Rocznik Muzealny. [R.] 12: 2009/2012 [dr.:] 2013 s. 98-108.

Dzieje Szkoły Podstawowej nr 3 w Rudzie Śląskiej (obecnie Zespół Szkół Ponadgimnazjalnych nr 7), od $1908 \mathrm{r}$.

310. GLENSK Urszula: Przytułki dla dzieci w międzywojennej Polsce. [W:] Margines społeczny Drugiej Rzeczypospolitej. Red. nauk. Mateusz Rodak. Warszawa 2013 s. 119-138.

311. GUCWA Aleksander: 140 lat szkoły w Sękowej. [W:] Sękowa. Z kart 650 lat historii wsi. Praca zbior. pod red. Piotra Gryglaszewskiego. Sękowa 2013 s. 241-259.

312. KIEŁKOWSKI Wojciech: Dzieje Szkoły Podstawowej im. Pawła Kojzara w Mnichu (1873-2013). Jastrzębie-Zdrój 2013 Black Unicorn ss. 319, nlb. 1, il.

313. KLOCH Bogdan: Z dziejów Domu Dziecka w Rybniku. Od Domu opieki dla sierot oraz starców do współczesnego Domu Dziecka. W stulecie działalności, 1913-2013. Rybnik 2013 Dom Dziecka; Muzeum ss. nlb. 2, 172, nlb. 4, il., sum. (Zeszyty Rybnickie. Monografie). 
314. KOSZELA Aleksander, Matyja Iwona: Jubileusz 65-lecia Zespołu Szkół nr 1 im. prof. Wilhelma Rotkiewicza w Dzierżoniowie. Rocznik Dzierżoniowski. T. 21: 2011 [dr.:] 2012 s. 147-149, tabl. 2.

Uzup.: Rząsa Janina: Radiobuda i samorządowcy. Tamże s. 150-151.

315. KRONIKA szkolna - źródło wiedzy o przeszłości. Wyjątki z kroniki wybrała Magdalena Prucnal. Kwartalnik Czudecki. R. 7: 2005 nr 1 s. 19.

Szkoła Podstawowa w Czudcu, 1934 r.

316. KRONIKA szkoły w Kolonii koło Kartuz. Cz. 1: 1801-1915. [Wyd.] Benedykt Karczewski. Kościerskie Zeszyty Muzealne. [Z.] 7: 2013 s. 93-147.

317. KRONIKA szkoły w Żeglcach 1880-1959. Oprac. Paweł Przetacznik. Żeglice-Krosno 2013 Jakulski Zbigniew ss. 160, tabl. 8, il.

Szkoła Podstawowa im. Karola Klobassy-Zrenckiego.

318. KRYSIAK Dominik: Szwedzka misja charytatywna a kwestia utworzenia domu dziecka w Mikołajkach (1946-1949). Meritum. T. 1: 2009 s. 163-177, sum.

319. KRYSOWATA Jolanta: Skrzydło anioła. Historia tajnego ośrodka dla koreańskich sierot. Inspiracja Patrick Yoka. Warszawa 2013 Świat Książki ss. 267, nlb. 2, tabl. 16, il.

Państ. Ośr. Wychowawczy w Płakowicach na Dolnym Śląsku.

320. KUBERCZYK Urszula: 120 lat minęło... Portret. Rocznik Głogówecki. Nr 3: 2009 s. $323-326$.

Szkoła Podstawowa w Biedrzychowicach.

321. MATERIAŁY do dziejów parafii ewangelicko-augsburskiej w Wieluniu. [Cz.] 2. [Wyd.] Zdzisław Włodarczyk. Rocznik Wieluński. T. 13: 2013 s. 145-148.

Z 1864 r.: 1. Opis szkoły ewangelickiej i mieszkania nauczyciela; 2. Raport władz Wielunia, kolegium kościelnego i opiekuna szkoły do naczelnika powiatu wieluńskiego o stanie szkoły ewangelickiej.

Cz. 1. Tamże. T. 7: 2007.

322. MAZUR Edward: Historia Szkoły Podstawowej w Biesnej. W stulecie istnienia (1912/13-2012/13). Biesna-Tuchów 2013 Stow. Miłośn. Wsi Biesna; Mała Poligrafia Redemptorystów ss. 264 , il.

323. MYJAK Józef: 110 lat szkoły w Lipniku. Oraz zespół aut. Marek Lis, Jadwiga Garnuszek, Joanna Ozdoba. Lipnik-Sandomierz 2013 Myjakpress „Folwark Miejski” ss. 171, il. (Lipnioviana; 2).

Zespół Szkół im. prof. Józefa Mikułowskiego-Pomorskiego, XX-XXI w.

324. OD DWÓCH stuleci dla dzieci. Księga pamiątkowa wydana z okazji jubileuszu 200-lecia Szkoły Podstawowej nr 31 w Krakowie. Kraków 2013 Szkoła Podstawowa nr 31 ss. 74, nlb. 6, il.

325. OGRODNICKA-BURGHARDT Anna: Sławię was wspomnieniami. Wspomnienia opracowano z okazji 200-lecia Szkoły Podstawowej w Żołyni 1818-2018 oraz Spotkań Rocznikowych Wychowanków w latach 2013-2018. Żołynia 2013 Gm. Ośr. Kultury ss. 63, nlb. 1, tabl. 16, il.

326. PATOLETA Małgorzata, Ziąbka Bogumiła: W pamięci zapisane. 50-lecie Szkoły Podstawowej w Rąbieniu. Rąbień 2013 Szkoła Podstawowa im. ks. Stefana kard. Wyszyńskiego Prymasa Tysiąclecia ss. 224, il.

327. PIETRASZEK Ewa: Pół wieku „Czwórki”. 50 lat Szkoły Podstawowej nr 4 im. ks. bpa Ignacego Krasickiego w Jaśle. Rocznik Jasielski. T. 7: 2012 s. 57-71.

Od 1962 r. 
328. PODKOWA Donata: 100-lecie szkoły w Toszku. Rocznik Muzeum w Gliwicach. T. 24: 2013 s. 345-384, sum., Zsfg.

329. PRZETACZNIK Paweł: Jubileusz 130. rocznicy istnienia Szkoły Podstawowej im. Karola Klobassy-Zrenckiego w Żeglcach, 1883-2013. Krosno-Żeglce 2013 Jaskulski Zbigniew ss. nlb. 20, il.

330. PRZYBYLSKA Barbara: Historia Szkoły Podstawowej nr 1 w Głogówku. Portret. Rocznik Gtogówecki. Nr 3: 2009 s. 327-331.

Od $1945 \mathrm{r}$.

331. RAŚ Danuta: Skarby cieszyńskiej trówły - Zakład Wychowawczy w Cieszynie (1912-1937). Historia, ludzie, praca. Kraków 2013 Oficyna Wydawnicza „Impuls” ss. 263, il.

332. SKRZYNECKA Anna: Dzieje szkoły we Wsoli 1898-2013. Monografia jubileuszowa. Wsola-Radom 2013 Zespół Szkół Publ.; Wydaw. Nauk. Inst. Technologii Eksploatacji - PIB ss. 236, il.

333. SZKOŁA na polance. Opowieść o Szkole Podstawowej nr 6 w Augustowie 1948-2013. Koncepcja wydaw., oprac. Janina Osewska. Augustów 2013 Dom pod Brzozą ss. 159, nlb. 1, tabl. 32, il.

334. SZKOŁA pod Modrzewiami. Szkoła Podstawowa nr 3 im. Janusza Korczaka w Porębie. Red. Zdzisław Kluźniak [i in.]. Zawiercie 2013 PUHW Axon ss. 72, il.

335. TĘCZA Józef: Wspomnienia wychowanka domu dziecka w Obłówce. My, Sybiracy. Nr 24: 2013 s. 42-46.

336. TRADYCJA edukacja, przygoda. O szkole podstawowej w Orzepowicach. RybnikKatowice 2013 Studio Noa ss. 66, il. Zespół Szkolno-Przedszkolny nr 7, Szkoła Podstawowa nr 32 im. Alfreda Szklarskiego w Rybniku.

337. WOŹNIAK Hieronim: Zarys dziejów Szkoły Podstawowej nr 5 imienia Hugona Kołłątaja w Żywcu. Gronie. Nr 10: 2010 s. 11-52.

Od 1964 r.

338. Z BIEGIEM lat. Historia szkoły w Wielogłowach w świetle starych kronik. Aut. Janusz Bielec, Janusz Rojek, Franciszek Szarata, Anna Turek. Wielogłowy-Nowy Sącz 2013 Fund. im. Gizów przy Zespole Szkół; Nova Sandec ss. 119, nlb. 1, il.

339. Z DZIEJÓW Szkoły w Babicy. Kwartalnik Czudecki. R. 13: 2011 nr 4 s. 18-19.

\section{Szkoły ponadpodstawowe}

340. BARAN Bazyli: Trzynastka znów triumfuje. Kilka informacji o XIII Liceum Ogólnokształcącym w Szczecinie. Kronika Szczecina. Nr 31: 2012 [dr.:] 2013 s. 119-122.

341. BARTCZAK-GOLDBERG Dorota, Leśniewska Stanisława, Bartczak-Fechati Ewelina: Szkoła Podstawowa im. Ofiar Pacyfikacji Brodziszewa 1939 w Brodziszewie 1913-2013. Poznań 2013 Przeds. Wielobranżowe Interfund ss. 96, il. 
342. BUGAJSKA-WIĘCŁAWSKA Joanna: Program wychowawczy Szkoły Handlowej i Gimnazjów Księży Pijarów w Lidzie. [W:] Z historii polskich pijarów. 350-lecie Polskiej Prowincji Zakonu Pijarów. Pod red. Mariusza Ausza. Kraków 2013 s. 245-262.

343. DAWNIEJ i dziś. Zespół red. Joanna Doroszewska [i in.]. Bydgoszcz-Żnin 2013 Margraf; na zlec. LO im. Braci Śniadeckich ss. 223, nlb. 1, il.

90 lat gimnazjum i LO im. Braci Śniadeckich w Żninie, 1923-2013.

344. DZIEJE Zespołu Szkół im. Marii Skłodowskiej-Curie w Działoszynie 1963-2013. W oparciu o dokumentację szkoły oprac. Renata Wojtal, Małgorzata Wolna. Działoszyn 2013 Zespół Szkół im. Marii Skłodowskiej-Curie ss. 176, il.

345. FRANECKI Antoni: Liceum Ogólnokształcące im. Henryka Kamieńskiego w RudzieHucie. Chełm 2013 TAWA Taurogiński Waldemar ss. 96, il.

XIX-XX w.

Rec.: Kiernikowski Paweł, Rocznik Chetmski. T. 17: 2013 s. 395-396.

346. GIERMAKOWSKI Marian: Zamoy to my. II Liceum Ogólnokształcące im. Hetmana Jana Zamoyskiego w Lublinie. Lublin 2013 Petit; na zlec. II LO im. Hetmana Jana Zamoyskiego ss. 72 , il. + dod. ss. XII.

347. KACZYŃSKA Alicja: Pod znakiem „książki i złotego pióra”, czyli dzieje szkoły Zofii z Wróblewskich Kurmanowej w Warszawie w latach 1903-1944. Oprac. Jolanta Niklewska. Almanach Muzealny. T. 7: 2013 s. 212-237.

Na podst. maszynopisu z archiwum Muzeum Historycznego m.st. Warszawy.

348. KASPRZAK Zenon: II Liceum Ogólnokształcące im. Władysława Broniewskiego w Koszalinie - historia i wspomnienia nie tylko sentymentalne. Rocznik Koszaliński. Nr 40: 2012 s. $103-112$.

W 1. 1949-2012.

349. KOBIŃSKA Joanna: 70 lat liceum w Puszczy Mariańskiej. Puszcza Mariańska 2013 LO im. Czesława Tańskiego ss. nlb. 2, 118, il.

350. KSIĄŻKA pamiątkowa z okazji jubileuszu 65-lecia Liceum Ogólnokształcącego im. Marii Konopnickiej w Jedliczu. Pod red. Małgorzaty Durdy. Miejsce Piastowe 2013 LO im. Marii Konopnickiej ss. 108, tabl. 48, il.

351. KSIĘGA wspomnień... raz na sto lat. Liceum Ogólnokształcące im. Joachima Chreptowicza w Ostrowcu Świętokrzyskim 1913-2013. Pod red. Ewy Stencel, Urszuli Heby, Barbary Podsiadło. Ostrowiec Świętokrzyski-Starachowice 2013 U.P.Z.P. „Dorand” T.S.Cisek ss. 447, nlb. 7, il.

352. KUBRAK Zygmunt: Gimnazjum i Liceum Ogólnokształcące im. Tadeusza Kościuszki w Lubaczowie 1913-2013. Księga jubileuszowa. Rzeszów 2013 Podkarpacki Inst. Książki i Marketingu ss. 310, nlb. 2, il.

353. MATEOSZEK Andrzej: Muzeum Szkolne im. Pelagii Kwapulińskiej w Zespole Szkół Ogólnokształcących nr 3 w Rudzie Śląskiej-Kochłowicach w latach 1969-2009. Rudzki Rocznik Muzealny. [R.] 12: 2009/2012 [dr.:] 2013 s. 109-116.

354. MIKOŁAJCZAK Edmund: Kasprowiczanie. Mały słownik biograficzny wychowanków Gimnazjum i Liceum Jana Kasprowicza w Inowrocławiu. Inowrocław 2013 Stow. Wychowanków Gimnazjum i Liceum Jana Kasprowicza; Drukarnia Pozkal ss. 286, nlb. 2, il. Stow. Wychowanków 
Gimnazjum i Liceum Jana Kasprowicza w Inowrocławiu, Gimnazjum i Liceum Jana Kasprowicza w Inowrocławiu.

XIX-XX w.

355. OLEJNIK Tadeusz: Pensja i Gimnazjum Humanistyczne Żeńskie Pelagii Zasadzińskiej w Wieluniu 1883-1939. Wieluń 2013 Wieluńskie Tow. Nauk. ss. 102, nlb. 2, il. (Biblioteka Wieluńskiego Towarzystwa Naukowego; t. 17).

356. PRZEWŁOCKI Adam: O ludziach i wydarzeniach z lat szkolnych. Oprac. Arkadiusz St. Więch, Norbert Sokołowski. Dębica 2013 Muzeum i Archiwum Szkolne I LO im. Króla Władysława Jagiełły ss. 56. Muzeum i Archiwum Szkolne I Liceum Ogólnokształcącego im. Króla Władysława Jagiełły. (Źródła Gimnazjalne).

Wspomnienia z 1. 1901-1918.

357. PRZYWOŁANE $\mathrm{z}$ historii, ocalone $\mathrm{z}$ pamięci. Gimnazjum i liceum w Kościanie w latach 1923-2013. Praca zbiorowa. Pod red. Violetty Julkowskiej. Kościan 2013 Stow. Absolwentów Gimnazjum i Liceum ss. 238, il.

Treść: Julkowska V.: Wstęp s. 9-11; Kościański Rafał, Kram Dariusz: Z kart historii gimnazjum i liceum w Kościanie s. 13-61; Trosiak Cezary: Portret uczniów „Kolberga” s. 63-79; Hordecki Bartosz: Świat wartości i świat symboli. Kilka uwag na temat retoryki. Wspomnienia czasów licealnych s. 80-91; Julkowska V.: O formacyjnym charakterze kształcenia i wychowania w kościańskim gimnazjum i liceum s. 92-101; Florkowski Wojciech J.: Reguły gry s. 102-103; Skroban-Gnacy Aleksandra: Dawni nauczyciele w świetle opublikowanych wspomnień s. 104-115; Janiszewska Sylwia: Wspomnienia nauczycieli w świetle wywiadów s. 116-126; Pogorzelska-Albińska Czesława, Szymkowiak Renata, Skroban-Gnacy A.: I Liceum Ogólnokształcące im. Oskara Kolberga w latach 1994/95-2007/8 s. 129-169; I Liceum Ogólnokształcące im. Oskara Kolberga w latach 2008/09-2012/13. Oprac. Małgorzata Andersz i in. s. 170-209; Śliwiński Eugeniusz: Stowarzyszenie Absolwentów Gimnazjum i Liceum w Kościanie w latach 1992-2013 s. 211-226.

358. ROMANIUK Zbigniew: Gimnazjum i Liceum im. Tadeusza Kościuszki w Bielsku Podlaskim w latach 1918-1944. Bielsk Podlaski 2013 Kom. Organizacyjny Zjazdów Wychowawców i Wychowanków Gimnazjum i Liceum im. Tadeusza Kościuszki ss. 208, il.

359. [STO dwadzieścia pięć] 125 lat „Szczepanika”. Księga pamiątkowa 1888-2013. Zespół red. Krystyna Kenar [i in.]. Krosno 2013 Arete ss. 383, nlb. 1, il.

Zespół Szkół Ponadgimnazjalnych nr 1 im. Jana Szczepanika w Krośnie.

360. [STULECIE] 100-lecie szkoły przy Królewskiej. Zespół red. Anna Kaczorowska [i in.] Łódź 2013 Piktor ss. 115, il.

Zespół Szkół Ogólnokształcących nr 5 im. Juliana Tuwima w Łodzi.

361. SZKOŁA Rydzyńska. Dzieło życia Tadeusza Łopuszańskiego. Red. Edyta Żebrowska. Rydzyna-Warszawa 2013 Kawdruk ss. 157, nlb. 3, il.

Treść: Wierzbicki Zbigniew T.: Życie i dzieło Tadeusza Jana Łopuszańskiego [1874-1955] s. 11-13; Zajkiewicz Andrzej: Szkoła Doświadczalna Gimnazjum i Liceum im. XX. Sułkowskich w Rydzynie s. 14-34; Ostrowski Maciej: Wychowanie fizyczne i turystyka w szkole w Rydzynie s. 35-44; Gliński Jan Bohdan, Wierzbicki Z. T.: Próby kontynuacji idei Szkoły Rydzyńskiej s. 45-51; Kalendarium działań Zarządu Fundacji im. Tadeusza Łopuszańskiego s. 54-74; Gliński J. B.: Dwie siostrzane fundacje Fundacja im. Sułkowskich w Rydzynie i Fundacja im. Tadeusza Łopuszańskiego s. 75-78; Nauczyciele Szkoły Rydzyńskiej s. 79-106; Uczniowie Szkoły Rydzyńskiej s. 107-152; Maki na jeziorach. Z Henrykiem Jaszczewskim, byłym Rydzyniakiem, znanym konstruktorem żaglówek serii MAK rozmawia M. Ostrowski s. 153-159.

362. ŚNIADECCZYCY. Zachowane w pamięci, dyktowane sercem. Wspomnienia nauczycieli i absolwentów Liceum Ogólnokształcącego im. Jana Śniadeckiego w Kielcach. Zespół red. Magdalena Herzog [i in.]. Kielce 2013 Jedność ss. 96, il.

Wydane w 110-lecie szkoły, 1903-1913. 
363. TAK BYŁO... na Karłowicach, w X LO. Red. Anna Wiącek, Krzysztof Maciej Krasuski. Wrocław 2013 Oficyna Wydaw. Atut ss. 187, il.

Antologia wspomnień maturzystów X LO we Wrocławiu z 1963 r.

364. TRADYCJA i dzień dzisiejszy siennickiej szkoły. Zespół red.: Krystyna Bakuła, Scholastyka Bartoszczak-Gadaj, Tadeusz Gnoiński, Maria Laskowska, Bolesław Sianecki, Jerzy Smoliński. Siennica 2013 Stow. Absolwentów i Wychowanków Szkół Siennickich ss. 95, nlb. 1, il.

Treść: Laskowska M.: Historia Koła Sienniczan oraz Stowarzyszenia Absolwentów i Wychowanków Szkół Siennickich - kalendarium s. 5-15; Czajka Stanisław: Pierwsze zjazdy absolwentów siennickiego seminarium: I zjazd w 1923 roku, II zjazd w 1933 roku s. 19-27; Gnoiński T.: Zapomniany zjazd sienniczan w 1946 roku s. 28-32; Czajka S.: Jak powstało i czym jest dziś muzeum siennickich szkół s. 32-36; Sianecki B.: Publikacje wydane przez Koło Sienniczan oraz Stowarzyszenie Absolwentów i Wychowanków Szkół Siennickich s. 37-44; Smoliński J.: Stowarzyszenie Absolwentów i Wychowanków Szkół Siennickich s. 45-51; Sianecki B.: Więzi Stowarzyszenia sienniczan ze szkołą i środowiskiem s. 51-60; Urbaniak Magdalena, Laskowska M.: Informacja o sympozjum naukowym: Myśl pedagogiczna dziś i w przeszłości. 145 lat tradycji kształcenia pedagogicznego w Siennicy s. 60-64; Jackowska Anna: Codzienne życie siennickiej szkoły s. 64-65; Spotkania po latach s. 66-78; Moja szkoła, moja praca s. 80-93; Skład Zarządu Stowarzyszenia Absolwentów i Wychowanków Szkół Siennickich w okresie od 30 maja 2009 r. do 8 czerwca 2013 r. s. 94-95.

365. TROC Krzysztof Bogusław, Walczak Krzysztof, Więcław Józef: Absolwent. Torun 2013 Agencja Reklamowo-Wydawnicza Art.-O, Krzysztof Oleksiak ss. nlb. 2, 88, il.

I Liceum Ogólnokształcące im. Adama Asnyka w Kaliszu.

366. TRZEŚNIOWSKA Mieczysława, Pawlikowski Radosław: Profesorowie gimnazjum i liceum w Brzozowie w latach 1909-1939. Brzozów 2013 Muzeum Region. im. Adama Fastnachta ss. 286, il.

367. W POSZUKIWANIU szkolnych dni. 95 lat szkoły średniej w Szczekocinach we wspomnieniach i dokumentach (1918-2013). V Ogólnoszkolny zjazd absolwentów, 1 czerwca 2013 r. Red. Tadeusz Stolarski. Szczekociny 2013 Stow. Absolwentów i Przyj. Szkoły Średniej w Szczekocinach ss. 252, nlb. 2, tabl. 7, il. + dysk optyczny

(CD-ROM).

Treść: Stolarski T.: Wstęp s. 7-10; Szkoła w roku jubileuszowym: Wtorek Anna: Myśleć szerzej i wyżej (wywiad z dyrektor Ewą Ludynią) s. 11-15; Hymn szkolny s. 16-17; Sikora Anna, Bryła Zbigniew: Kalendarium ważniejszych wydarzeń w latach 2008-2013 s. 18-49; Orliński Andrzej: Szkoła jubilatka s. 50-59; Orliński Czesław: Śladami początków szkoły średniej w Szczekocinach s. 60-63; Stolarski T.: O Stowarzyszeniu Absolwentów i Przyjaciół Szkoły Średniej w Szczekocinach s. 64-66; Drej Elżbieta: Nasi „złoci” absolwenci s. 67; Stolarski T.: Nasi znani absolwenci s. 68-86; Wspomnienia dalekie i bliskie s. 87-243; Stolarski T.: O tych, co odeszli... s. 244-252.

368. WOŹNICA Anita, Chróścicki Jan: Moja szkoła... Z dziejów gimnazjum i liceum im. B. Prusa. Siedlce 2013 I LO im. B. Prusa ss. 263, nlb. 1, il.

W Siedlcach, XX-XXI w.

369. ZAKLĘCI w kamieniu. Album poświęcony nieżyjącym nauczycielom Gimnazjum i Liceum Ogólnokształcącego w Strzyżowie. Zespół red. Violetta Wietecha [i in.]. StrzyżówRzeszów 2013 Stow. Absolwentów i Przyj. LO im. A. Mickiewicza; „Bonus Liber” Wydaw. i Drukarnia Diec. Rzeszowskiej ss. 53, nlb. 1, il.

Treść: Wspominani nauczyciele: Józefa Olszewska, Edmund Gibczyński, Anna Hajduk, Józef Kosiak, Maria Konieczkowska, Piotr Pirga, Helena Olech, Eleonora Kawa, Helena Buczek-Kut, Zygmunt Leśniak, Zbigniew Aleksander Patryn, Bolesław Baranowski, Antoni Wójcik, Stefan Kołodziejczyk, Jan Przybyła, Stanisława Lenart, Kazimierz Tokarski, Maria Ostrowska-Adamczyk, Maria Matuszewska s. 5-45; Zielińska Agnieszka: Życie szkolne w Gimnazjum i Liceum Ogólnokształcącym w Strzyżowie s. 46-49; Zaklęci w kamieniu [spis nazwisk] s. 50-52. 
370. ZATRZYMAĆ... czasu przemijanie. Wspomnienia o Liceum Ogólnokształcącym im. Przemysława II w Rogoźnie Wlkp. Zebrała i oprac. Zofia Lück. Sławno 2013 Margraf ss. 224, nlb. 1 , il.

XIX-XXI w.

371. ZESPÓŁ Szkół Salezjańskich Lux Sapientiae w Sokołowie Podlaskim. Salezjańskie Liceum Ogólnokształcące, Salezjańskie Gimnazjum. 20 lat działalności wychowawczej i dydaktycznej (1993-2013). Red. Anna Adynowska [i in.]. Warszawa 2013 Wydaw. Salezjańskie ss. 151, nlb. 1 , il.

\section{Szkoły zawodowe}

372. DRZEWIECKI Jerzy: 60 lat (1950-2010) Zespołu Szkół Żeglugi Śródlądowej im. Bohaterów Westerplatte w Kędzierzynie-Koźlu. Szkice Kędzierzyńsko-Kozielskie. [T.] 13: 2010 s. $54-70$.

373. GÓRZNA Anna: Na Libelta 4. Monografia Zespołu Szkół Ekonomicznych im. Stanisława Staszica w Międzyrzeczu. Współaut. Stefan Cyraniak, Jadwiga Żuk-Czyż, Waldemar Walaszek. Międzyrzecz 2013 Limonki.pl; na zlec. Zesp. Szkół Ekonom. ss. 236, il.

374. GRACZYK-GRZELUSZKA Jolanta: Zespół Szkół Technicznych i Hutniczych im. Marii Skłodowskiej-Curie w Koninie i jego rola w kształceniu dorosłych oraz młodzieży regionu konińskiego. Rocznik Koniński. T. 18: 2013 s. 205-213.

Od 1962 r.

375. GRYŚ Iwona, Weigelt Iwona: Zespół Szkół Ogólnokształcących. Bibliotheca Bielaviana. [R. 2]: 2010 [dr.:] 2011 s. 281-283.

W Bielawie.

376. JAŚKIEWICZ Aleksander: Szkoła Przemysłu Ludowego w Częstochowie. Rocznik Muzeum Częstochowskiego. T. 12: 2011/2012 [dr.:] 2013 s. 189-197, sum.

Od $1922 \mathrm{r}$.

377. MEDYCZNE Studium Zawodowe w Śremie 1972-1993. Zespół red. Barbara Siwińska, Ewa Dolińska, Karol Doliński. Śrem 2007 Pol. Tow. Lekarskie. Koło ss. 101, il.

378. MELBECHOWSKA-LUTY Aleksandra: Kilka przypomnień o zakopiańskiej Szkole Przemysłu Drzewnego i jej snycerzach (1876-1939). Konteksty. R. 67: 2013 nr 1 s. 141-146, sum. s. $247-248$.

379. MERKURY. Jednodniówka XII Zjazdu Absolwentów Szkół Handlowych i Ekonomicznych w Kaliszu 1-2 czerwca 2013 r. Red. Ewa Andrysiak. Kalisz 2013 Zakład Usług Poligraficznych Dangraf ss. 133, il.

Zespół Szkół Ekonomicznych w Kaliszu, XX-XXI w.

380. MOLIŃSKI Wiesław: Jelenie ryczą w Rogozińcu. Wyd. 2., popr. Namysłów 2013 Namislavia, Tadeusz Wincewicz i S-ka ss. 168, il.

Wspomnienia autora (ur. 1958) o nauce w Technikum Leśnym w Rogozińcu.

Wyd. 1. 2012.

381. OD SPÓŁDZIELCZOŚCI do współczesności. 50 lat Zespołu Szkół nr 2 im. Tadeusza Rejtana w Rzeszowie. Pod red. Piotra Wisza. Rzeszów 2013 Resprint ss. 231, il., sum. 
382. PIERWSZA średnia szkoła techniczna w Stalowej Woli. Oprac. Jan Sztobryn. Warszawa 2013 Omikron ss. 304, il.

Zespół Szkół Ponadgimnazjalnych nr 1 im. gen. Władysława Sikorskiego; Antologia wspomnień, XX-XXI w.

383. [PIĘĆDZIESIĄT] 50 lat Rypińskiego Ekonomika (monografia historyczna). Pod red. Piotra Gałkowskiego. Rypin 2013 Pow. Rypiński ss. 413, il.

Zespół Szkół nr 2 im. Unii Europejskiej.

384. PRZESZŁOŚĆ zachowana w pamięci. Zespół red. Iwona Żurawska [i in.]. Grudziądz 2010 Studio Grafiki Komputerowej ss. 240, il.

Zespół Szkół Gastronomiczno-Hotelarskich w Grudziądzu.

385. SIENKIEWICZ-BLOCH Eleonora: Pierwsze dwudziestolecie Państwowego Liceum Muzycznego w Bydgoszczy we wspomnieniach świadka jego sześćdziesięcioletniej historii. [W:] Świadkowie kultury muzycznej na Pomorzu i Kujawach. Pod red. Aleksandry Kłaput-Wiśniewskiej. Bydgoszcz 2013 s. 137-148.

386. STANIK Wilhelm: Historia „Budowlanki” w Głogówku. Portret. Rocznik Głogówecki. Nr 3: 2009 s. $315-322$.

Od XIX w.

387. [STO] 100 lat Krzyżewskiej Alma Mater 1913-2013. Zespół red. Wioletta Gierlachowska [i in.]. Krzyżewo 2013 Zespół Szkół Rolniczych im. Stefanii Karpowicz ss. 182, nlb. 2, tabl. 16, il.

Z treści: Stefania Karpowicz [1876-1974] - rys biograficzny s. 9-27; Z kart przeszłości szkoły s. 29-78; W nowej rzeczywistości s. 79-101; Izba Pamięci i sztandar s. 105-107; Olimpiady i konkursy s. 109-114; Osiągnięcia sportowe s. 115-122; Kadra pedagogiczna s. 123-131; Absolwenci 1913-2013 s. 135-172; Wspomnienia absolwentów s. 173-178.

388. SZCZEPAŃSKI Stanisław Maria: Wspomnienia marynarskiego mundurka. Opowieści morskie i śródlądowe. Gdynia 2013 Porta Mare ss. 140, il.

Wspomnienia autora (ur. 1956) o nauce w Technikum Żeglugi Śródlądowej we Wrocławiu.

389. [SZEŚĆDZIESIĄT] 60 lat minęło... Rys monograficzny. IV zjazd absolwentów, 31 maja 2013 r. Bełżyce-Lublin 2013 Zespół Szkół im. Mikołaja Kopernika; Polihymnia ss. 194, il. Zespół Szkół im. Mikołaja Kopernika.

W Bełżcach.

390. SZKOLNICTWO muzyczne na Dolnym Śląsku po drugiej wojnie światowej. Lata 1945 -1960. T. 1: Historia, wspomnienia. Red. Eugeniusz Sąsiadek. Wrocław 2013 Pol. Stow. Pedagogów Śpiewu ss. 129, il. Pol. Stow. Pedagogów Śpiewu, Stow. Pol. Artystów Muzyków. Oddz. we Wrocławiu.

Treść: Sąsiadek E.: Nota redaktorska s. 7-8; Strzyżewska-Marciniak Barbara: Szkolnictwo muzyczne we Wrocławiu w latach powojennych s. 11-20; Kościukiewicz Kazimierz: Państwowa Wyższa Szkoła Muzyczna we Wrocławiu 1955-1960 s. 21-29; Kofin Ewa: Państwowa Średnia Szkoła Muzyczna we Wrocławiu s. 30-43; Dymek Hanna: Państwowa Podstawowa Szkoła Muzyczna i Państwowe Liceum Muzyczne we Wrocławiu s. 44-52; Strzyżewska-Marciniak B.: Państwowa Szkoła Muzyczna nr 2 we Wrocławiu s. 53-66; Werner Barbara Ewa: Szkoła Muzyczna w jeleniej Górze w latach 1945-1960 s. 67-71; Szumiło Agnieszka Justyna: Szkoła Muzyczna w Legnicy w latach $1945-1960$ s. 72-82; Swoboda Krystyna: Początek szkolnictwa muzycznego w Wałbrzychu 1945-1960 s. 83-94; Kościukiewicz K.: Szkoła Muzyczna w Świdnicy s. 95-104; Sąsiadek E.: Pedagogika wokalna we Wrocławiu w latach 1948-1960. Refleksje osobiste s. 107-118; Sąsiadek E.: Franciszka Rotter-Platówna [1894-1974], wybitna artystka i pedagog. Wspomnienia s. 119-129.

391. UŚCIŃSKI Franciszek: Jak powstała w Bolesławcu Szkoła Muzyczna. Rocznik Bolestawiecki. T. 5: 2012 [dr.:] 2013 s. 107-109.

Lata 80. XX w. 
392. WARCHOŁ-SOBIESIAK Maria: Założyciele i ich dzieło. 80 lat Państwowej Szkoły Muzycznej im. Karola i Antoniego Szafranków w Rybniku. Rybnik-Katowice 2013 Państ. Szkoła Muzyczna I i II stopnia im. Karola i Antoniego Szafranków; Drukarnia Archidiec. ss. 63, il.

393. WĘCLEWSKA Anna: Tradycje szkoły włókienniczej w Bielawie. Bibliotheca Bielaviana. [R. 2]: 2010 [dr.:] 2011 s. 25-36.

Od $1900 \mathrm{r}$.

394. WNĘK Jan: Szkoła Przemysłowa Żeńska Towarzystwa Szkoły Ludowej w Nowym Sączu (1926-1937). Rocznik Sadecki. T. 41: 2013 s. 223-242.

395. WSPOMNIENIA absolwentów „Radiobudy” rozpoczynających naukę w latach 1946, 47, 48 i 49 (spisane dla potomności). Pod red. Leszka Kiepała. Dzierżoniów 2013 Studio Edytor ss. 87.

Zespół Szkół nr 1 im. prof. Wilhelma Rotkiewicza w Dzierżoniowie.

396. ZESPÓŁ Szkół Techniki Rolniczej im. Wincentego Witosa w Piotrowicach 1963-2013. Pół wieku tradycji. Lublin-Piotrowice 2013 Polihymnia ss. 246, il.

Treść: Zieleniak Katarzyna: Z historii Piotrowic s. 5-6; Zieleniak K.: Powstanie i rozwój szkoły s. 7-10; Baran Bolesław: Kalendarium 40-lecia szkoły s. 11-24; Baran Janusz: Kadra pedagogiczna s. 25-29; Praca dydaktyczno-wychowawcza szkoły w latach 1963-2003 s. 30-47; Ważne wydarzenia w życiu szkoły s. 48-67; Nowakowska Joanna: Absolwenci s. 68-106.

\section{Zakłady kształcenia nauczycieli (z wyjątkiem szkół wyższych)}

397. ALBUM wspomnień absolwentów i profesorów Liceum Pedagogicznego $\mathrm{nr} 3$ w Inowrocławiu w latach 1945-1970. Red. prow. Wincenty Mazurek; red. Barbara Litwicka, Urszula Kaczmarek. Inowrocław 2013 Pozkal ss. 425, nlb. 1, il. Absolwenci i Sympatycy Liceum Pedagog. im. Władysława Spasowskiego w Inowrocławiu.

398. BŁASZCZYK Władysław: Zarys dziejów Państwowego Liceum Pedagogicznego w Kutnie (1945-1948). Kutnowskie Zeszyty Regionalne. T. 17: 2013 s. 163-206.

399. BUJKIEWICZ Zbigniew: Seminarium przedszkolanek Anny Borchers w Zielonej Górze (1905-1945). Studia Zielonogórskie. T. 19: 2013 s. 37-48.

400. BURTNY Kazimierz, Cimała Bogdan, Jasiński Zenon: Nieść kaganek oświaty... Dzieje kształcenia nauczycieli w Kluczborku (1953-1975). Opole 2013 Inst. Nauk Pedagog. Uniw. Opolskiego ss. 378, tabl. 8, il.

401. CHOJNOWSKA Elżbieta: Kształcenie kompetencji zawodowych nauczycieli w seminariach nauczycielskich w Łomży w okresie Drugiej Rzeczypospolitej. Przegląd HistorycznoOświatowy. R. 56: $2013 \mathrm{nr}$ 1/2 s. 119-128.

402. GĄSIOROWSKI Andrzej, Kamilewicz-Rucińska Danuta: Z dziejów Seminarium Nauczycielskiego w Trokach na Wileńszczyźnie (1924-1950). Przeglad Historyczno-Oświatowy. R. 56: $2013 \mathrm{nr} \mathrm{3/4} \mathrm{s.} \mathrm{37-55.}$

403. HOCH Stefania, Leśniewska Wanda, Nemec Danuta: 30 lat działalności Koła Absolwentek Warszawskiej Szkoły Pielęgniarstwa. Warszawa 2013 [B. w.] ss. 61, il.

404. KARAŚ Marlena: Kształcenie nauczycieli w Wieluniu (1945-2013). Rocznik Wieluński. T. 13: 2013 s. 49-69. 
405. KWIATEK Jolanta: Kształcenie nauczycielek na Górnym Śląsku. (Od lat 30. XIX w. do I wojny światowej). Kwartalnik Opolski. R. 54: 2008 nr 1 s. 3-20.

406. SAPIA-DREWNIAK Eleonora: Droga do zawodu nauczycielskiego. Górnoślązaczki u progu II Rzeczypospolitej. Przegląd Historyczno-Oświatowy. R. 56: 2013 nr 1/2 s. 31-42.

407. STANKIEWICZ Ryszard: Edukacja nauczycieli w II Rzeczypospolitej. Żary 2013 Wydaw. Nauk. Łużyckiej Wyższej Szkoły Humanist. im. Jana Benedykta Solfy ss. 116. Łużycka Wyższa Szkoła Humanist. im. Jana Benedykta Solfy w Żarach.

408. WINCENCIAK Witold: Kształcenie nauczycieli w Łomży. Zarys dziejów (1914-2014). Wyd. wznowione i rozsz. Warszawa 2012 Oficyna Wydawnicza Aspra-Jr ss. 274, nlb. 1, il.

Rec.: Kijowski Jerzy, Studia Lomżyńskie. T. 23: 2012 s. 311-315.

\section{Szkoły wyższe \\ Akademia Górniczo-Hutnicza}

409. [DZIEWIĘĆDZIESIĄT] 90 lat „Metalurgii” w fotografiach i wspomnieniach. Oprac. Ireneusz Suliga. Kraków 2012 Wydaw. Nauk. Akapit ss. 389, il.

Wydział Inżynierii Metali i Informatyki Przemysłowej Akademii Górniczo-Hutniczej w Krakowie.

\section{Katolicki Uniwersytet Lubelski Jana Pawła II}

410. WALEWANDER Edward: Katedra Pedagogiki Porównawczej Katolickiego Uniwersytetu Lubelskiego Jana Pawła II. Lublin 2013 Liber Duo ss. 43, il.

Po 1989 r.

\section{Kolegium Nauczycielskie w Wieluniu}

411. LEWIK-TSIRIGOTIS Ewa, Tsirigotis Konstantinos: Kształcenie nauczycieli w Kolegium Nauczycielskim w Wieluniu w latach 2001-2005. Rocznik Wieluński. T. 12: 2012 s. 37-61, sum.

\section{Państwowa Wyższa Szkoła Filmowa, Telewizyjna i Teatralna w Łodzi}

412. POWIDOKI. Szkoła Filmowa w Łodzi. Afterimages. Film School in Łódź. Zespół red. Marzena Bomanowska [i in.]; tł. Piotr Czarnota, Paweł Maj. Łódź 2013 Wydaw. Bibl. Państ. Wyższej Szkoły Filmowej, Telewizyjnej i Teatralnej ss. nlb. 302, tabl. 2, il.

Tekst równol. pol., ang.

\section{Państwowa Wyższa Szkoła Zawodowa w Koninie}

413. CIEŚLAK Robert, Zimny Artur: Rola i znaczenie PWSZ w Koninie dla rozwoju miasta i regionu. Rocznik Koniński. T. 18: 2013 s. 87-107.

Od 1998 r. 


\section{Politechnika Gdańska}

414. STUDIA i absolwenci Oddziału Geologii Politechniki Gdańskiej 1951-1960. Red. wiodący Stanisław Downorowicz. Gdańsk-Lubin 2013 Tow. Konsultantów Pol. Oddz. ss. 304, il.

Zawiera też spisy osobowe, biografie i wspomnienia.

\section{Politechnika Warszawska}

415. ELEKTRONIKA rocznik 1961. Obrazek pokolenia. Zbiór esejów, wspomnień i refleksji. Praca zbiorowa. Aut. Antek Nowakowski [i in.]. Warszawa-Falbogi Wielkie 2013 Nakł. własnym grupy absolwentów Wydz. Elektroniki Politech. Warszawskiej; Agencja Projektowo-Wydawnicza Mak ss. 232, nlb. 3, il.

\section{Politechnika Wrocławska}

416. PIERWSI Absolwenci Politechniki Wrocławskiej. Biografie. Oprac. Kazimierz Banyś. Wrocław 2013 Oficyna Wydaw. Politech. Wrocławskiej ss. 109, nlb. 1, il.

Treść: Banyś K.: Od Glanowa do Wrocławia s. 5-29; Dyga Stefan: Mój wymarzony zawód s. 31-33; Gliszczyński Mieczysław Jerzy: Diariusz spotkań z architekturą w latach 1945-2010 s. 35-55; Gwiazdowski Lechosław: Gdyby nie wojna! s. 57-63; Kaźmierowicz Wiktor: Okruchy wspomnień z czasów studiów odbywanych na Politechnice Wrocławskiej w latach 1945-1950 s. 65-70; Kolman Romuald: Faktografia wspomnień s. 71-73; Maciaszek Stanisław: Krótkie wspomnienia z długiego życia s. 75-82; Rogowski Józef: Moje wspomnienia ze studiów na Politechnice Wrocławskiej s. 83-98; Skibiński Włodzimierz: Wspomnienia s. 99-101; Węgrzyn Roman: Politechnika i śpiew s. 103-109.

\section{Szkoła Główna Gospodarstwa Wiejskiego}

417. PAMIĘTNIK absolwentów Wydziału Weterynaryjnego Uniwersytetu Warszawskiego 1951-1952 i Szkoły Głównej Gospodarstwa Wiejskiego 1952-1957. Oprac. red. Jerzy Kita. Warszawa 2013 Akces ss. 119, nlb. 1, il.

Treść: Kalendarium ważniejszych wydarzeń w rozwoju uczelni weterynaryjnej w Warszawie [od 1824 r.] s. 11-13; Nasi Profesorowie s. 14-16; Lista absolwentów rocznika 1951-1957 Wydziału Weterynaryjnego UW/SGGW [słownik biograficzny] s. 17-91; Aneks s. 93; Po 50 latach - spojrzenie wstecz s. 94-105; Zdjęcia pamiątkowe z uroczystości 40-lecia ukończenia studiów, 1997 rok s. 106-108; Zdjęcia pamiątkowe z uroczystości wręczenia „Złotych dyplomów”, 2007 rok s. 109-120.

418. [SZEŚĆDZIESIĄT] 60 lat Wydziału Nauk Ekonomicznych Szkoły Głównej Gospodarstwa Wiejskiego w Warszawie. Księga jubileuszowa 1953-2013. Red. nauk.: Maciej Stawicki, Agnieszka Wojewódzka-Wiewiórska. Warszawa 2013 Wydaw. SGGW ss. 343, nlb. 1, tabl. 16, il.

Treść: Gołębiewski Jarosław: Wstęp s. 5-6; Cz. 1. Historia Wydziału Nauk Ekonomicznych SGGW: Ziętara Wojciech: Geneza i rozwój Wydziału s. 9-30; Kosicki Janusz: Wspomnienia i refleksje naocznego świadka narodzin i obserwatora sześćdziesięcioletniej działalności Wydziału Ekonomicznego SGGW s. 31-39; Adamowicz Mieczysław: Dwie kadencje - stan wojenny i przedwiośnie transformacji s. 40-51; Józwiak Wojciech: Wspomnienia z okresu pełnienia funkcji dziekana Wydziału s. 52-59; Wojtaszek Zygmunt: Znaczenie i rola opiekuna w rozwoju naukowym pracownika Wydziału Nauk Ekonomicznych SGGW s. 60-69; Bernacki Andrzej Marcin: Refleksje z okazji 60-lecia Wydziału Ekonomiczno-Rolniczego SGGW (obecnie Wydziału Nauk Ekonomicznych) s. 70-82; Górecki Jan: Refleksje i wspomnienia w związku z Jubileuszem 60-lecia Wydziału Nauk Ekonomicznych SGGW s. 83-89; Lewandowski Janusz: Moje pół wieku pracy na 
Wydziale Nauk Ekonomicznych SGGW s. 90-91; Podstawka Marian: Refleksje z kierowania Wydziałem Ekonomiczno-Rolniczym w latach 1999-2005 s. 92-96; Klepacki Bogdan: Ewolucja Wydziału Ekonomiczno-Rolniczego/Nauk Ekonomicznych w latach transformacji społeczno-gospodarczej i okres wyzwań integracyjnych s. 97-104; Stopnie i tytuły naukowe nadane na Wydziale Ekonomiczno-Rolniczym i Wydziale Nauk Ekonomicznych SGGW s. 105-152; Cz. 2. Wydział Nauk Ekonomicznych SGGW obecnie s. 153-344.

419. [TRZYDZIEŚCI pięć] 35 lat Wydziału Nauk o Żywieniu Człowieka i Konsumpcji. Mater. oprac. Anna Brzozowska [i in.]. Warszawa 2013 Wydaw. SGGW ss. 239, tabl. 19, il. Szkoła Gł. Gospodarstwa Wiejskiego w Warszawie.

Treść: Gutkowska Krystyna: Wstęp s. 5-6; Prof. dr hab., dr h.c. Stanisław Berger - twórca Wydziału s. 7-9; Rozwój Wydziału [w 1. 1977-2012] s. 11-37; Jednostki Wydziału Nauk o Żywieniu Człowieka i Konsumpcji s. 39-88; Koła naukowe s. 88-92; Oferta dydaktyczna s. 93-95; Rozwój naukowy kadry s. 97-105; Emerytowani profesorowie s. 107-127; Wspomnienia o zmarłych pracownikach Wydziału s. 129-151; Absolwenci s. 153-239.

\section{Uniwersytet im. Adama Mickiewicza}

420. DZIEJE nauk geograficznych i geologicznych na Uniwersytecie w Poznaniu. Praca zbiorowa. T. 1: Historia. Przewodn. zespołu red. Marek Marciniak. Poznań 2012 Wydaw. PTPN s. 467, nlb. 1, il. +1 dysk optyczny (CD-ROM). UAM w Poznaniu. Wydz. Nauk Geograficznych i Geologicznych, PTPN.

Z treści: Marciniak M.: Wprowadzenie s. 13-15; Początki geografii i geologii w Wielkopolsce: Kaniecki Alfred: Rozwój i dorobek nauk geograficznych s. 19-45; Skoczylas Janusz: Początki geologii s. 46-64; Kaniecki A., Skoczylas J.: Podróżnicy - geografowie i geolodzy s. 65-73; Kaniecki A., Bełka Zdzisław: Geografia i geologia niemiecka s. 74-80; Nauki o Ziemi na Wszechnicy Piastowskiej i Uniwersytecie Poznańskim (1919-1939) s. 81-116; Okres okupacji niemieckiej (1939-1945) s. 117-128; Geografia i geologia na Wydziale Matematyczno-Przyrodniczym (1945-1951) s. 129-152; Wydział Biologii i Nauk o Ziemi (1951-1984) s. 153-200; Wydział Nauk Geograficznych i Geologicznych (1984-2010) s. 201-324; Działalność dydaktyczna w latach 1919-2010 s. 325-364; Struktura organizacyjna Wydziału Nauk Geograficznych i Geologicznych s. 365-458; Posłowie s. 459-468.

Toż. T. 2: Biografie. Poznań 2012 ss. 280, il. +1 dysk optyczny (CD-ROM).

Z treści: Wszechnica Piastowska i Uniwersytet Poznański (1919-1939) s. 9-74; Okupacja niemiecka (1939-1945) s. 75-84; Wydział Matematyczno-Przyrodniczy (1945-1951) s. 85-112; Wydział Biologii i Nauk o Ziemi (1951-1984) s. 113-182; Wydział Nauk Geograficznych i Geologicznych (od 1984) s. 183-228; Doktoraty Honoris Causa s. 229-281.

421. KRÓTKA historia Instytutów i Katedr Wydziału Neofilologii Uniwersytetu im. Adama Mickiewicza w Poznaniu. Publikacja przygotowana $\mathrm{z}$ okazji 25-lecia istnienia Wydziału Neofilologii UAM (1988-2013). Red. Teresa Tomaszkiewicz, Stanisław Puppel. Poznań 2013 Zakł. Graficzny UAM ss. 113, il.

422. PRZERWANA kadencja rektorska Stefana Dąbrowskiego w świetle dokumentów archiwalnych. [Wyd.] Anita Magowska. Acta Medicorum Polonorum. R. 1: 2011 s. 141-153, abstr. $1946 \mathrm{r}$.

\section{Uniwersytet Jagielloński}

423. GĄSOWSKI Tomasz: Collegium Wróblewskiego. Kraków 2013 Księg. Akademicka ss. 133, tabl. 17, il., sum. (Historia Budynków Uniwersytetu Jagiellońskiego).

424. JEZIORO Artur: Polityczny aspekt walki o autonomię Uniwersytetu Jagiellońskiego w czasach Wolnego Miasta Krakowa. Politeja. 2010 nr 1 s. 29-51, abstr. 
425. OSOWSKI Mirosław: Uniwersyteckie lata. Kraków (1963-1968). Stalowa Wola 2013 Kazimierz Linda ss. 179, il.

Wspomnienia autora (ur. 1942) ze studiów polonistycznych na UJ.

426. STINIA Maria: Jagiellonian University as a factor of Kraków city development in the second half of the nineteenth and the beginning of the twentieth centuries. Studia Historyczne. R. 56: 2013 z. 4 s. 587-596, streszcz.

Do $1912 \mathrm{r}$.

427. ŚLIŻ Małgorzata: Żydowscy studenci z Białegostoku na Uniwersytecie Jagiellońskim (1867-1939). [W:] Żydzi Wschodniej Polski. Ser. 1: Świadectwa i interpretacje. Red. nauk. Barbara Olech i Jarosław Ławski. Białystok 2013 s. 101-108.

428. [WASYLEWSKI Stanisław]: Alma Mater krakowską wychowawczynią Ślązaków. Fragment niewydanej, zmienionej wersji „Na Śląsku Opolskim” Stanisława Wasylewskiego. [Wyd. i wstęp] Jerzy Pośpiech. Kwartalnik Opolski. R. 53: 2007 nr 1 s. 165-180.

429. WISZ Piotr: W poszukiwaniu wiedzy i wartości. Wykładowcy Wydziału Teologicznego Uniwersytetu Jagiellońskiego w latach 1945-1954. Kraków 2012 Wydaw. La Salette ss. 386.

Rec.: Siwak Wacław, Premislia Christiana. T. 15: 2012/2013 [dr.:] 2013 s. 385-387.

430. ZEMANEK Alicja: Sto lat Instytutu Botaniki Uniwersytetu Jagiellońskiego (1913-2013). Kraków 2013 Inst. Botaniki UJ ss. 307, il., sum. Inst. Botaniki UJ.

431. ZEMANEK Bogdan: Ogród Botaniczny Uniwersytetu Jagiellońskiego. 230 lat nauki i społeczeństwa. Zdj. Andrzej Mróz, Maria Lankosz-Mróz. Kraków 2013 Inst. Botaniki UJ ss. 91, nlb. 11, il. Ogród Botaniczny - Inst. Botaniki UJ.

\section{Uniwersytet Jana Kochanowskiego}

432. KRASIŃSKA Izabela: Instytut Bibliotekoznawstwa i Dziennikarstwa Uniwersytetu Jana Kochanowskiego w Kielcach. Historia i dzień dzisiejszy. Forum Bibliotek Medycznych. R. 6: 2013 nr 2 s. 66-119, sum.

\section{Uniwersytet Lwowski}

433. PIEKARSKI Michał: Z dziejów muzykologii na Uniwersytecie Lwowskim (1912-1939). Rocznik Lwowski. 2010/2011 [dr.:] 2011 s. 83-98.

434. PODRAZA Antoni: Studenci historii na Uniwersytecie Lwowskim w latach II wojny światowej. Ze wspomnień własnych. [W:] Antoni Podraza (1920-2008). Człowiek, uczony, polityk. Pod red. Stanisława Grodziskiego i Grzegorza Niecia. Kraków 2013 s. 73-82.

\section{Uniwersytet Łódzki}

435. KONIECZNA Jadwiga: Katedra Bibliotekoznawstwa i Informacji Naukowej Uniwersytetu Łódzkiego - historia i współczesność. Forum Bibliotek Medycznych. R. 6: 2013 nr 2 s. 160-177, sum. 
Od 1945 r.

436. KOWALEWSKA Urszula, Mikłajuk Lidia: Programy kształcenia Katedry Bibliotekoznawstwa i Informacji Naukowej Uniwersytetu Łódzkiego w latach 1945-2011. Acta Universitatis Lodziensis. Folia Librorum. [Vol.] 17: 2013 s. 203-215, sum.

\section{Uniwersytet Marii Curie-Skłodowskiej}

437. SZTUKA i edukacja 1972-2012. 40 lat kształcenia artystycznego na Uniwersytecie Marii Curie-Skłodowskiej w Lublinie. Oprac. i red. merytoryczna Piotr Majewski. Lublin 2013 Wydz. Artystyczny UMCS ss. 285, nlb. 1, il.

Z treści: Cz. 1. Instytut Sztuk Pięknych: Współczesność i historia s. 19-37; Dyscypliny kształcenia artystycznego s. 40-94; Cz. 2. Instytut Muzyki: Wspomnienia i aktualia s. 103-119; Dyscypliny kształcenia muzycznego s. 122-163; Kto jest kim w Instytucie Muzyki; Cz. 3. Między uczelnią a agorą: Sztuki wizualne s. 192-231; Muzyka s. 234-248; Cz. 4. Apendyks s. 252-281.

\section{Uniwersytet Medyczny w Łodzi}

438. ŻMUDA Ryszard: Jubileusz 10-lecia „Kronikarza” (2002-2012) czasopisma Uniwersytetu Medycznego w Łodzi. Forum Bibliotek Medycznych. R. 6: 2013 nr 1 s. 111-134, sum.

Uzup.: Cichocki Piotr Tomasz: Bibliografia zawartości „Kronikarza” (2002/2003-2011/2012). Tamże s. $537-579$.

\section{Uniwersytet Papieski Jana Pawła II}

439. SZCZUREK Jan D.: The gratitude of the university 615 th academic year at the Pontifical University of John Paul II in Krakow. Analecta Cracoviensia. [T.] 44: 2012 s. 323-349.

Rok 2012.

\section{Uniwersytet Pedagogiczny w Krakowie}

440. GRZYWACZ Halina, Ruta Adam: Instytut Informacji Naukowej i Bibliotekoznawstwa Uniwersytetu Pedagogicznego im. Komisji Edukacji Narodowej w Krakowie. Forum Bibliotek Medycznych. R. 6: 2013 nr 2 s. 120-144, sum.

Od 1973 r.

441. WOJTYCZA Janusz: Działalność naukowa i dydaktyczna Katedry Edukacji Obronnej Akademii Pedagogicznej/Uniwersytetu Pedagogicznego im. Komisji Edukacji Narodowej w latach 2000-2009. Annales Universitatis Paedagogicae Cracoviensis. Folia 144: Studia de Securitate et Educatione Civili. [T.] 3: 2013 s. 11-24, abstr.

442. ZŁOTY Jubileusz ukończenia studiów geograficznych 1963-2013. Pod red. Irminy Zioło i Tomasza Rachwała. Kraków 2013 Inst. Geografii. Uniw. Pedagog. im. KEN ss. 100, il. Inst. Geografii. Uniw. Pedagog. im. KEN.

Treść: Zioło I.: Droga życiowa absolwentów geografii - rocznik 1958-1963 s. 6-12; [Autobiografie i wspomnienia] s. 13-77; Rachwał T.: Współczesne kierunki rozwoju Instytutu Geografii Uniwersytetu Pedagogicznego w Krakowie s. 78-99. 


\section{Uniwersytet Przyrodniczy w Lublinie}

443. KSIĘGA pamiątkowa absolwentów Wydziału Weterynaryjnego Wyższej Szkoły Rolniczej w Lublinie 1957-1963. Jubileusz 50-lecia uzyskania dyplomów lekarza weterynarii 1963-2013. Zespół red. Mirosław Łakomy, Marek Musialik, Stefan Noworyta. Będzin [i in.] 2013 FPHU Joanna Baron ss. 123, il. Uniw. Przyrodniczy w Lublinie. Wydz. Medycyny Weterynaryjnej.

\section{Uniwersytet Przyrodniczy w Lublinie}

444. [SZEŚĆDZIESIĘCIOLECIE] 60-lecie Wydziału Biologii i Hodowli Zwierząt. Księga pamiątkowa. Materiały do publikacji zebrał i oprac. zespół w składzie Zygmunt Litwińczuk [i in.]. Lublin 2013 Wydaw. Uniw. Przyrodniczego ss. 225, nlb. 2, il.

Treść: Od Wydziału Zootechnicznego UMCS do Wydziału Biologii i Hodowli Zwierząt UP s. 5-47; Działalność jednostek naukowo-dydaktycznych s. 49-187; Wspomnienia absolwentów Wydziału s. 188-198; Absolwenci Wydziału w latach 2003-2012 s. 199-225.

\section{Uniwersytet Przyrodniczy w Poznaniu}

445. GRACZYK Małgorzata, Krzyszkowska Jolanta, Szczepańska-Álvarez Anna: Katedra Metod Matematycznych i Statystycznych na Uniwersytecie Przyrodniczym w Poznaniu 1963-2013. Poznań 2013 Bogucki Wydaw. Nauk. ss. 204, nlb. 4, il.

\section{Uniwersytet Rolniczy w Krakowie}

446. TRADYCJA i współczesność kultury studenckiej w Uniwersytecie Rolniczym im. Hugona Kołłątaja w Krakowie. Wybrane aspekty fenomenu. Red. Michał Szanduła. Kraków 2013 Episteme ss. 385, il. CKS Centrum Kultury Studenckiej Uniw. Rolniczego w Krakowie.

Treść: „Bez tytułu”. Szymon Sikorski rozmawia z Martą Stanek Piątkowką, Aleksym Gałką, Markiem Myślińskim i Andrzejem Pawłowskim s. 11-33; Pawłowski Andrzej: O rajdach, złazach i studenckiej turystyce w naszej uczelni - garść faktów i wspomnień z minionego półwiecza s. 35-67; Nowak Czesław: Kultura studencka - perspektywa studenta lat 70-tych, mieszkańca akademika s. 69-79; Pawłowski A.: Skalni - studencki zespół góralski Uniwersytetu Rolniczego w Krakowie s. 79-98; Dziadowiec Joanna: Studencki zespół góralski Skalni UR - autentyczność tradycji w niespokrewnionej rodzinie s. 99-136; Bachleda-Księdzulorz Franciszek: Mowa weselna - wypytowiny - jako część historii 50-lecia studenckiego zespołu góralskiego Skalni w Krakowie s. 137-146; Brzuchacz Józef: Kieby nom growali mijałyby lata... s. 147-158; Szombara Ela: Jak se tak spóminom moi czasy w Skalnych... s. 159-160; Brzuchacz J.: Poeci wśród Skalnych s. 161-170; Wiech Kazimierz: Kultura studencka oczami nauczyciela akademickiego s. 171-188; Gutowska-Kuźmicz Joanna: ChUR [Chór Uniwersytetu Rolniczego], czyli śpiewający Uniwersytet Rolniczy w Krakowie s. 189-255; Worecka Magdalena: Muzyka leśna na Uniwersytecie Rolniczym w Krakowie s. 257-300; Korta Adam: Samorządność studencka a kultura s. 301-308; Szanduła M.: Nowe formy realizacji misji kulturowej - wybrane aspekty działalności Klubu Akademickiego Arka Uniwersytetu Rolniczego w Krakowie w latach 2009-2013 s. 309-331; Łoś Robert: Jak studenci Uniwersytetu Rolniczego pomagają ratować ludzkie życie s. 333-342; Klęczar Aneta, Klęczar Krzysztof: O początkach studenckiego Koła Przyjaciół Dzieci s. 343-350; Hostyńska Anna: Moje artystyczne wspomnienia s. 351-360; Małopolska Martyna, Wołkowski Piotr: Kabaret „O co chodzi?" s. 361-385. 


\section{Uniwersytet Rzeszowski}

447. PIĘĆDZIESIĄT lat polonistyki rzeszowskiej. Księga jubileuszowa. Pod red. Jolanty Pasterskiej, Anny Niewolak-Krzywdy. Rzeszów 2013 Wydaw. Uniw. Rzeszowskiego ss. 408, il.

Z treści: Pasterski Janusz: Słowo wstępne. Półwiecze polonistyki rzeszowskiej 1963-2013 s. 9-13; Poczet kierowników Katedry Literatury i Języka Polskiego oraz dyrektorów Instytutu Filologii Polskiej s. 14-18; Rozdz. 1: Powstanie i rozwój polonistyki rzeszowskiej s. 19-118; Rozdz. 2: Instytut Filologii Polskiej. Działalność naukowa i społeczna s. 119-196; Rozdz. 3: Oferta edukacyjna s. 197-213; Rozdz. 4: „Okiem wspomnień". Polonistyka we wspomnieniach pracowników, absolwentów i studentów s. 214-368; Historia rzeszowskiej polonistyki w fotografii s. $369-408$.

\section{Uniwersytet Śląski}

448. INSTYTUT Bibliotekoznawstwa i Informacji Naukowej Uniwersytetu Śląskiego w Katowicach. Droga od genezy po rok bieżący (1974-2013). Oprac. zespół pod kier. prof. dr hab. Elżbiety Gądek. Forum Bibliotek Medycznych. R. 6: 2013 nr 2 s. 47-65, sum.

449. KURPIERZ Tomasz: Studencki stan wojenny na Uniwersytecie Śląskim. CzasyPismo. 2012 nr 2 s. $156-165$.

\section{Uniwersytet Warmińsko-Mazurski}

450. MIKROHISTORIA Kortowa. Konteksty, refleksje, narracje. Red. nauk. Joanna Maria Garbula. Olsztyn 2012 Wydaw. Uniw. Warmińsko-Mazurskiego ss. 212, il., sum.

Dzielnica Olsztyna.

Z treści: Achremczyk Stanisław: Kortowo - od folwarku do uniwersyteckiego miasteczka s. 59-75; Chłosta Jan: Trzy osobliwe tajemnice dawnego Kortowa s. 76-88; Dąbkowska Barbara: Cieszyńskie korzenie Uniwersytetu Warmińsko-Mazurskiego w Olsztynie s. 89-106; Zakrzewska Aldona: Olsztyńskie Duszpasterstwo Akademickie w Kortowie s. 107-130; Radziszewska Maria: Związek Nauczycielstwa Polskiego w kortowskim środowisku akademickim s. 131-157; Sawczuk Wiktor: Kulturotwórcza rola kortowskiego kampusu uczelnianego s. 174-186.

451. OLSZTYN uniwersytecki. Historia, wspomnienia, refleksje. Pod red. Andrzeja Farugi. Olsztyn 2013 Stow. Absolwentów Uniw. Warmińsko-Mazurskiego ss. 702, il.

Z treści: Górecki Ryszard: Miastotwórcze oddziaływanie uniwersytetu w Olsztynie s. 9-37; Achremczyk Stanisław: Kortowo - od folwarku do uniwersyteckiego miasteczka s. 39-53; Faruga A.: Zakątki Kortowa w fotografii s. 55-84; Dąbkowska Barbara: Cieszyńskie korzenie - dzieje Wyższej Szkoły gospodarstwa Wiejskiego w Cieszynie zapisane w Archiwum Uniwersytetu Warmińsko-Mazurskiego w Olsztynie s. 85-98; Z panteonu współzałożycieli Wyższej Szkoły Rolniczej w Olsztynie - pierwszej polskiej uczelni akademickiej na Warmii i Mazurach. Oprac. A. Faruga s. 99-114; Dąbkowska B.: Doktorzy honoris causa WSR - ART w Olsztynie s. 115-124; Pilarek Bolesław: Doktorzy honoris causa Uniwersytetu Warmińsko-Mazurskiego w Olsztynie s. 125-140; Pilarek B.: Najwyższa godność akademicka dla wybitnych s. 141-160; Pilarek B.: Poczet rektorów Uniwersytetu Warmińsko-Mazurskiego w Olsztynie. Poczet rektorów WSR - ART s. 161-178; Pilarek B.: Poczet rektorów WSN - WSP s. 179-184; Koncicki Andrzej: Historia Wydziału Medycyny Weterynaryjnej (1966-2012) s. 185-210; Sobotka Wiesław: Wydział Bioinżynierii Zwierząt - dawniej i dziś s. 211-227; Guzowski Jan: Wydział Teologii w Olsztynie s. 229-250; Majer Piotr: Geneza i rozwój Wydziału Prawa i Administracji Uniwersytetu Warmińsko-Mazurskiego s. 251-273; Korol Halina, Błoński Benedykt: Wawrzyczki uniwersyteckie, czyli... Chór im. prof. W. Wawrzyczka w Uniwersytecie Warmińsko-Mazurskim s. 275-289; Guziur Janusz: Rozśpiewany „Mistrz” s. 291-298; Pilarek B.: Michał Oczapowski prekursorem nowoczesnego rolnictwa s. 299-304; Gawlik Tadeusz: AZS Olsztyn - lekka atletyka, wczoraj i dziś s. 305-324; 
[Wspomnienia] s. 325-676; Faruga A.: Stowarzyszenie Absolwentów Uniwersytetu Warmińsko-Mazurskiego w Olsztynie w kadencji 2009-2013 s. 677-687; Faruga A.: Cieszyniacy na Warmii i Mazurach s. 689-702.

\section{Uniwersytet Warszawski}

452. KSIĘGA jubileuszowa Wydziału Nauk Ekonomicznych Uniwersytetu Warszawskiego 1953-2013. Red. nauk. Cecylia Leszczyńska. Warszawa 2013 Wydawnictwa Uniw. Warszawskiego ss. 361 , il.

453. LUDWIN Filip: Katedra Historii Doktryn Politycznych i Prawnych Wydziału Prawa i Administracji Uniwersytetu Warszawskiego - 50 lat. Dzieje oraz informacja o działalności. Studia Iuridica. T. 56: 2013 s. 211-222, sum.

\section{Uniwersytet Wrocławski}

454. BŁASZCZYK Tomasz: Problemy z ortodoksją na Wydziale Teologii Katolickiej Uniwersytetu Wrocławskiego w XIX stuleciu. Saeculum Christianum. R. 19: 2012 nr 1 s. 59-82, Zsfg.

455. JAREMKÓW Monika: Instytut Informacji Naukowej i Bibliotekoznawstwa Uniwersytetu Wrocławskiego - umiejętne (po)łącznenie tradycji i nowoczesności. Forum Bibliotek Medycznych. R. 6: $2013 \mathrm{nr} 2$ s. $178-187$, sum.

Od $1956 \mathrm{r}$.

456. KSIĘGA Pamiątkowa Jubileuszu 200-lecia utworzenia Państwowego Uniwersytetu we Wroclawiu. Commemorative book for the 200th anniversary of the establishment of the State University in Wrocław. T. 2: Universitas litterarum Wratislaviensis 1811-1945. Red. Jan Harasimowicz. Wrocław 2013 Wydaw. Uniw. Wrocławskiego ss. 694, il. (Acta Universitatis Wratislaviensis; No 3363).

Tekst równol. pol., ang.

Z treści: Harasimowicz J.: Słowo wstępne s. 6-7; Od Leopoldiny i Viadriny do pruskiego uniwersytetu państwowego: Schlňgel Karl: Odra w tradycji intelektualnej Europy Środkowej s. 10-19; Conrads Norbert: Akademia Leopoldyńska (1702-1811) s.20-43; Blänkner Reinhard: Uniwersytet Viadrina (1506-1811) s. 44-61; Dehnel Piotr: Wilhelma von Humboldta idea uniwersytetu s. 62-81; Harasimowicz J.: Universitas litterarum Wratislaviensis. Powstanie - ustrój - etapy rozwoju s. 82-121; Dorobek naukowy w latach 1811-1945 s. 123-469; Infrastruktura naukowo-dydaktyczna s. 471-587; Społeczność akademicka s. 589-637.

457. MŁYNARSKI Ryszard, Pisarski Grzegorz: Studenci z Reichenbach na Królewskim Śląskim Uniwersytecie Fryderyka Wilhelma III we Wrocławiu w latach 1880-1914. [Cz.1]. Rocznik Dzierżoniowski. T. 20: 2010 [dr.:] 2011 s. 38-50.

[Cz. 2] pt.: Dzierżoniowscy studenci na Śląskim Uniwersytecie Fryderyka Wilhelma we Wrocławiu w latach 1914-1945. Tamże. T. 21: 2011 [dr.:] 2012 s. 34-42.

458. PISARSKI Grzegorz: Studenci ze wsi ziemi kłodzkiej na Królewskim Śląskim Uniwersytecie im. Fryderyka Wilhelma we Wrocławiu w latach 1880-1920. Cz. 1. Stan na trzy semestry roku 1880. Zeszyty Muzeum Ziemi Kłodzkiej. [Z.] 12: 2013 s. 73-87, Zsfg., sum. 


\section{Uniwersytet Zielonogórski}

459. DOLAŃSKI Dariusz: Zielonogórska droga do uniwersytetu. 10-lecie Uniwersytetu Zielonogórskiego, 46-lecie zielonogórskiego środowiska akademickiego: Wyższa Szkoła Inżynierska (1965-1996), Politechnika Zielonogórska (1996-2001), Wyższa Szkoła Nauczycielska (1971-1973), Wyższa Szkoła Pedagogiczna (1973-2001), Uniwersytet Zielonogórski (2001...). Zielona Góra 2011 Oficyna Wydawnicza Uniw. Zielonogórskiego ss. 351, nlb. 1, il. + dodatek ss. VII, nlb. 1.

Toż. Wyd. 2. popr. i uzup. Zielona Góra 2012 ss. 355, nlb. 1, il.

\section{Wyższa Szkoła Nauczycielska w Kielcach}

460. MŁYNARCZYK-TOMCZYK Anita: Model naukowo-dydaktyczny Wyższych Szkół Nauczycielskich na przykładzie Zakładu Historii Wyższej Szkoły Nauczycielskiej w Kielcach (1969-1973). Między Wistą a Pilica. T. 14: 2013 s. 167-183, sum.

Wyższa Szkoła Oficerska Wojsk Lądowych im. generała Tadeusza Kościuszki

461. WYŻSZA Szkoła Oficerska Wojsk Lądowych imienia generała Tadeusza Kościuszki 1943-2013 - 70 lat. Oprac. Marek Kulczycki, Krzysztof Nowacki, Konrad Rudowski; aut. zdj. Marek Kańtoch [i in.]. Wrocław-Żagań 2013 Wyższa Szkoła Oficerska Wojsk Lądowych im. gen. Tadeusza Kościuszki; Wydaw. Gamb ss. 144, il.

Album fotografii.

\section{Wyższa Szkoła Pedagogiczna w Opolu}

462. ABSOLWENCI Wyższej Szkoły Pedagogicznej w Opolu - matematyka 1963/64-1968 Pół wieku później, czyli Co nam zostało z tych lat? Oprac. Krzysztof Borkowski i Jerzy Nowik. Opole 2013 Nowik ss. 159, il.

Antologia wspomnień.

463. DINDORF Wojciech: Na początku był „kabaret”. Narodziny. Na 60-lecie WSP/UO w Opolu. Lata 50-te XX wieku. Opole 2013 Wydaw. MS ss. 263, nlb. 1, il. + dysk optyczny (CD-ROM).

Początki Wyższej Szkoły Pedagogicznej w Opolu; zawiera też wspomnienia.

\section{Wyższe Seminarium Duchowne w Tarnowie}

464. NOWAK Adam: Wspomnijcie na minione dni. Z dziejów Wyższego Seminarium Duchownego w Tarnowie. Tarnów 2013 Wydaw. Diec. Tarnowskiej Biblos ss. 91, il.

XIX-XX w. 


\title{
IV. BIOGRAFIE
}

\author{
1. Zbiory życiorysów
}

465. ADAMIAK-PAWELEC Ewa: Leksykon nauczycieli polskich szkół przedmiotów ojczystych w Londynie w latach 1950-2010. Przedm. Włodzimierz Mier-Jędrzejowicz. Lublin 2012 Norbertinum ss. 173, nlb. 1, il.

466. BIOGRAFIE nauczycieli i pedagogów. Idee i programy. Red. Ryszard Skrzyniarz, Grzegorz Bujak, Katarzyna Kołtuniewicz. Lublin 2013 Episteme ss. 343, il., sum. KUL Jana Pawła II. Wydz. Nauk Społ. (Biblioteka Katedry Biografistyki Pedagogicznej; nr 2).

Z treści: Skrzyniarz R., Bujak G. Kołtuniewicz K.: Wstęp s. 9-12; Osobowość i autorytet nauczyciela: Grabowska Dorota: Autorytet nauczyciela w źródłach autobiograficznych XIX wieku s. 47-60; Pugacewicz Iwona H.: Wpływ biografii zbiorowych ojców-założycieli na kształtowanie modelu wychowawczego Szkoły Narodowej Dzieci Wychodźców Polskich w Paryżu s. 61-80; Twórcy i ich programy wychowawcze: Burzyńska-Kaniewska Krystyna: Idea samokształcenia charakteru w myśli edukacyjnej księdza Feliksa Bodzianowskiego w kontekście wielkopolskich korzeni biograficznych s. 107-116; Parzyszek Magdalena: Księdza Zygmunta Mościcickiego harmonia między duchowością a wychowaniem s. 117-132; Mołka Janusz: Podmiotowe i indywidualne traktowanie wychowanka w ujęciu księdza Mieczysława Kuznowicza s. 133-146; Rynio Alina: Edukacyjne oddziaływanie osobowego charyzmatu księdza Mieczysława Brzozowskiego s, 147-162; Skrzyniarz R.: Zygmunt Szczęsny Feliński - droga do świętości s. 163-188; Matus Irena: Projekty oświatowe kanonika brzeskiego Antoniego Sosnowskiego w perspektywie biograficznej s. 189-202; Kosacka Katarzyna: Działalność dydaktyczno-wychowawcza Zygmunta Bolesława Kukulskiego w Szkole Lubelskiej s. 203-216; Chęcińska Urszula: Pedagogia Joanny Kulmowej w kontekście autobiograficznym s. 217-228; Wyzwania edukacyjne i wychowawcze w świetle poszukiwań biograficznych: Szady Joanna: Metoda biograficzna w dydaktyce historii s. 231-242; Jasiak Dominika: Biogramy w podręcznikach historii - zmiana wzorców i form w ostatnim dwudziestoleciu s. 243-253; Król Katarzyna: Biografie w dydaktyce historii na podstawie „Pielgrzyma w Dobromilu” Izabeli Czartoryskiej s. 255-268; Sulik Monika: Osobisty wymiar doświadczeń związanych z andragogicznymi badaniami biograficznymi oraz z dydaktyką biograficzną s. 269-280; Gutowska Anna: Uczenie się dorosłych w sytuacji przyjaźni w andragogicznej perspektywie - egzemplifikacja badania w biografii tematycznej s. 281-300; Biografie w badaniach dziejów oświaty i wychowania: Micherda Magdalena: Organizacja i charakterystyka szkolnictwa polskiego na Zaolziu s. 303-318; Krzyżanowski Zdzisław: Szkolnictwo podstawowe w Gminie Gogoria w XX wieku s. 319-332; Partyka Wiesław: Bractwa religijne w guberni lubelskiej w XIX wieku - organizacje o charakterze religijno-patriotycznym s. 333-343.

467. BONDER Józefa: Kronika nauczycieli seniorów miasta i gminy Witnica 1945-2012. Witnica-Gorzów Wielkopolski 2013 Sonar ss. 172, il.

Słownik biograficzny.

468. BYLI wśród nas. Wspomnienia i biogramy. Pod red. Zenobii Knakiewicz, Wacława Jarmołowicza, Wiesławy Przybylskiej-Kapuścińskiej. Wyd. 4, uzup. Poznań 2013 Wydaw. Uniw. Ekonom. ss. 480, nlb. 3, il. Uniw. Ekonom. w Poznaniu.

Słownik biograficzny pracowników powstałej w 1926 r. Wyższej Szkoły Handlowej, następnie od 1950 r. Wyższej Szkoły Ekonomicznej, od 1974 r. Akad. Ekonomicznej i obecnie Uniw. Ekonomicznego w Poznaniu.

Wyd. 1. 1997.

469. GRĘDZIK-RADZIAK Agnieszka: Lista polskich nauczycieli z ziem północno-wschodnich II Rzeczypospolitej, ofiar represji niemieckich w latach 1941-1944. Cz. II A. Przeglad Historyczno-Oświatowy. R. 56: $2013 \mathrm{nr}$ 1/2 s. 129-193.

Cz. I. Tamże. R. 51: $2008 \mathrm{nr}$ 3/4.

470. GRZĄDZIELSKI Zbigniew: Biogramy wybitnych nauczycieli w regionie. Almanach Częstochowy. [T. 26]: 2013 s. 58-63. 
Region częstochowski: Jerzy Jan Długoszowski (1922-2009), Edward Polanowski (1936-1992), Konstanty Zajda (1903-1992).

471. HARCERSKI słownik biograficzny Kielecczyzny. Pod red. Andrzeja Rembalskiego. Kielce 2012 Agencja „JP” ss. 584, tabl. 11, il.

472. KOPIŃSKI Aleksander: W służbie oświaty polskiej - Sergiusz [1889-1955] i Helena [1897-1971] Halpernowie. (Studium biograficzno-genealogiczne). Cz. 1. Roczniki Łowickie. T. 10: 2013 s. $318-348$.

473. KRYŚCIAK Aneta: Pijarzy związani z Łowiczem i nauczyciele łowickiego kolegium (1668-1831). Roczniki Łowickie. T. 10: 2013 s. 38-100.

474. SŁOWNIK biograficzny polskiego ruchu młodowiejskiego. T. 3. Pod red. Elżbiety Wojtas-Ciborskiej. Warszawa 2013 MHPRL ss. 449, nlb. 1, il.

T. 1. 2009.

475. WYBRANI twórcy i ich idee pedagogiczne w Drugiej Rzeczypospolitej (1918-1939). Red. nauk. Wiesław Andrukowicz i Elżbieta Magiera. Szczecin 2012 Przeds. ProdukcyjnoHandlowe Zapol Dmochowski, Sobczyk ss. 202, sum.

Treść: Andrukowicz W., Magiera E.: Uwagi wstępne s. 5-12; Begier Katarzyna Maria: Zarys życia i twórczości Edwarda Abramowskiego (1868-1918) s. 13-27; Andrukowicz W.: Edward Abramowski - wszechstronny i odpowiedzialny humanista s. 28-47; Magiera E.: Edward Abramowski jako twórca koncepcji polskiego kooperatyzmu s. 48-70; Jankowski Robert: Zagadnienia organizacji szkolnictwa w myśli pedagogicznej Lucjana Zarzeckiego s. 71-95; Stankiewicz Adam: „Schemacie, kacie z kurtką na wacie”. O osobowościach społecznych w teorii Floriana Znanieckiego (1882-1958) s. 96-108; Król Joanna: Sławomir Czerwiński (1885-1931) - minister, polityk i pedagog s. 109-133; Koźmian Danuta: Poglądy pedeutologiczne i komparatystyczne Albina Jakiela (1900-1944) s. 134-151; Uszkiewicz Aneta: Sergiusz Hessen (1887-1950) - przedstawiciel pedagogiki kultury s. 152-158; Andrukowicz W.: Sergiusz Hessen - pedagog pytający o całość s. 159-177; Sowiński Andrzej Jakub: Dyskurs o podmiotowość w wychowaniu s. 178-202.

\section{Poszczególne biografie}

476. FLORKOWSKI Henryk: Andrzej z Kokorzyna (zm. ok. 1435) teolog, profesor i rektor Akademii Krakowskiej. Pamiętnik Towarzystwa Miłośników Ziemi Kościańskiej. T. 12: 2005/2008 [dr.:] 2008 s. 302-303.

477. KURZEJA-ŚWIĄTEK Maria: Michał Asanka-Japołł [1885-1953] - nauczyciel, publicysta z Sądecczyzny. Rocznik Sądecki. T. 41: 2013 s. 132-160.

478. WSPOMNIENIA o siostrze Jozafacie Bogolubow CR [1885-1955]. Zebrała i oprac. Ewa Hanter. Warszawa-Szydłowiec 2013 Ikona ss. 316.

Treść: Nowak Felicjanna: Życiorys s. Jozafaty Bogolubow CR s. 3-15; Józefowicz Aniela: „Buda” Eksperymentalny Ośrodek Pedagogiczny Sióstr Zmartwychwstania Pańskiego w Częstochowie s. 16-94; Koźmińska Anna: Jak trafiłam do „Budy” s. 95-179; Magnuska Janina: Wymodliła mi ocalenie i powołanie do sprawy Bożej (fragmenty wspomnień). Wspomnienia o pracy siostry Jozafaty z dziećmi s. 180-204; Siemiątkowska-Grabiec Anna: Teatr jako metoda samowychowania. Czego uczyliśmy się w Budzie s. 205-216; Król-Pospieszalska Donata: Uczyłam się i pomagałam siostrze Jozafacie uczyć dzieci s. 217-220; Pospieszalski Stanisław: Wychowanie twórcze w pracy pedagogicznej siostry Jozafaty Bogolubow s. 221-228; Pisarska Antonina: Buda - gorczycznym ziarnem szkoły w duchu ewangelicznym s. 229-230; Pisarska A., Pospieszalski S.: I co tu jest nowego (na marginesie pracy w Budzie) s. 231-232; Jankowska-Oryżyna Janina: Moja Święta - siostra Jozafata s. 233-237; Ostaszewska Kazimiera: Przygotowała mnie do zadania zleconego przez 
Opatrzność s. 238-239; Kaznowski Marian: Jak siostra Jozafata pracowała nad moim charakterem s. 240-245; Stanowski Wacław, Stanowski Stefan: W Budzie otrzymaliśmy wychowanie s. 246-249; Komarnicka Józefa: Rozmowy w cztery oczy s. 250-252; Ludkiewicz Janina Maria: Siostra Jozafata w moich osobistych wspomnieniach [oraz] jako pedagog s. 253-258; Markowska Urszula: Pedagog obdarzony charyzmatem s. 259-261; Chmielowska Bogusława: Pracowałyśmy razem nad historią Kościoła s. 262-265; Przybył Rozalia: Praca pedagogiczna siostry Jozafaty w „Budzie” s. 266-268; Kakietek Angelina: Wspomnienie o pracy siostry Jozafaty w latach 1931-38 s. 269-270; Bartel Bolesław: Siostra Jozafata była moją nauczycielką w latach 1933-34 s. 271; Tyras Andrzeja: Przychodziła z pomocą słabszym uczennicom poprzez zdolniejszą młodzież s. 272-275; Kwapisz Otylia Helena: Pan Bóg przysłonił w niej wielkie dary s. 276; Ryś Maciej: Współpraca siostry Jozafaty Bogolubow z pallotynami s. 277-283; Folejewski Feliks: Są takie spotkania, króre ja nazywam obecnością s. 284-293; Kuraciński Stanisław: Wychowywała kapłanów dla „sprawy dziecka” s. 294-297; Korycki Jan: Geniusz pedagogiczny siostry Jozafaty s. 298-300; Malewicz Leszek: Praca z siostrą Jozafatą zadecydowała o moim wyborze stanu s. 301-303; Komarnicka J.: Siostra Jozafata odchodzi do Boga s. 304-305; Czapla Stanisław: Przemówienie pogrzebowe s. 306-309; Ważniejsze daty z życia siostry Jozafaty s. 310-313.

479. JURCZYSZYN Marek: Mieczysław Brzeziński [1858-1911] pedagog - społecznik. Lublin 2012 Liber Duo ss. 429. (Biblioteka Pedagogiczna Katedry Pedagogiki Porównawczej Wydziału Nauk Społecznych Katolickiego Uniwersytetu Lubelskiego. Ser. A: Studia; 22).

Rec.: Doroszewski Jerzy, Przegląd Historyczno-Oświatowy. R. 56: 2013 nr 3/4 s. 192-194; Zieliński Zygmunt, Saeculum Christianum. R. 19: 2012 nr 2 s. 321-326.

480. GOŁDYN Piotr: Sławomir Czerwiński (1885-1931). Minister oświaty, przyjaciel Kalisza. Kalisz 2013 Kaliskie Tow. Przyj. Nauk ss. 82, nlb. 4, il. (Kaliszanie; 6).

481. KRAJEWSKI Miron: Najstarsza (104 lata) harcerka na Mazowszu - Tola z Rawskich Dobrowolska (1908-2012). Rocznik Mińskomazowiecki. T. 21: 2013 s. 199-206.

482. SOLARZ Adam: Wspomnienia o harcmistrz Eugenii Domalewskiej [1897-1973] instruktorze jeleniogórskiego harcerstwa. Jelenia Góra 2013 Adam Solarz ss. 96, il.

483. LACH Jan, Tracz Mariola: Jan Flis [1912-1993] - geograf, nauczyciel i mistrz. Rocznik Sądecki. T. 41: 2013 s. 509-511.

Sprawozdanie z konferencji, Kraków, 29 IX 2012 r.

484. WIĘCH Arkadiusz S.: Wychowawca polskości. Tadeusz Gawryś (1881-1914). Dębica 2013 Muzeum i Archiwum Szkolne przy I LO im. Króla Władysława Jagiełły ss. 46, nlb. 2, il.

485. BŁACHUTA Małgorzata, Lewandowska Barbara: Władysław Gąsiorek o swej matce Marii [Gąsiorek, 1898-1983], nauczycielce w Kolebach. Gronie. Nr 12: 2012 s. 219-236.

W aneksie: Adamus Antoni: Wspomnienia kierownika szkoły, następcy Marii Gąsiorek s. 237-238.

486. OŻÓG Maria E.: Bruno S. Gruszka (1881-1941). Lata edukacji szkolnej i uniwersyteckiej. Prace Historyczno-Archiwalne. T. 25: 2013 s. 155-166, sum.

W gimnazjum w Jarosławiu w 1. 1892-1900 i na studiach prawniczych we Lwowie w 1. 1905-1909.

487. MISZCZUK Marian: Naczelnik Adolf Zbigniew Heidrich (1899-1983). Biografia harcerska. Warszawa 2013 Tomiko Marian Miszczuk ss. 95, nlb. 1, il.

488. KONOPKA Witold: Magdalena Jacobi-Pawłowicz (1881-1954), profesor Instytutu Muzycznego i Państwowej Średniej Szkoły Muzycznej w Toruniu im. Karola Szymanowskiego. Rocznik Toruński. [T.] 39: 2012 s. 201-206.

489. MILUSKA Barbara: Zanikające akordy zmierzchu... Biografia Stanisława Jednacza [1924-2006] - nauczyciela, społecznika, szlachetnego człowieka. Puławy 2013 Tow. Przyj. Muzeum Oświatowego ss. 170, il. 
490. WOŹNIAK Hieronim: Michał Jeziorski [1892-1942] jako nauczyciel i pedagog. Gronie. Nr 13: 2013 s. 9-14.

491. MEUS Konrad: Lata gimnazjalne świętego Józefa (Biby) Bilczewskiego. Folia Historica Cracoviensia. Vol. 19: 2013 s. 279-296, sum.

Lata $1872-1880$

492. SŁAWIŃSKI Piotr: Ignacy Karpiński [1815/1817-1895] jako nauczyciel i popularyzator wiedzy. Kwartalnik Opolski. R. 58: 2012 nr 2/3 s. 163-176, sum.

493. ŚLĘCZKA Ryszard: Andrzej Kliś [1951-2011] - krakowski historyk edukacji. Biuletyn Historii Wychowania. [Nr] 29: 2013 s. 141-145.

494. PODSIADŁY Adam: Mauzoleum i Muzeum Jana Amosa Komeńskiego w Naarden. Rocznik Leszczyński. T. 13: 2013 s. 213-225.

Holandia, XIX-XX w.

495. BAJSAROWICZ Grażyna: Wspomnienie o Janie Kowalu [zm. 2011]. Rocznik Dzierżoniowski. T. 21: 2011 [dr.:] 2012 s. 218-219.

496. SIKORA Krystyna: Władysław Kruczek (1950-2011). Rocznik Sąecki. T. 41: 2013 s. $397-401$.

497. HOMICKI Bogusław: Kazimierz Lisiecki „Dziadek” [1902-1976]. Opowieść o naczelnym dziecku ulicy i jego ferajnie. Warszawa 2011 Przywrócić Dzieciństwo. Stow. Wychowanków i Przyj. Kazimierza Lisieckiego-Dziadka ss. 159, il.

498. KASPRZYK Damian: Zygmunt Luty (1897-1961), stoczkowski społecznik i nauczyciel. Zeszyty Wiejskie. Z. 14: 2009 s. 290-299.

Ze Stoczka Łukowskiego.

499. PROFESOR Mieczysław Lobocki [1929-2012]. Pedagog, teoretyk wychowania, humanista. Pod red. Barbary Wojciechowskiej-Charlak i Teresy Zubrzyckiej-Maciąg. Lublin 2013 Wydaw. UMCS ss. 118, tabl. 46, il.

500. BORZYSZKOWSKI Józef: Jan Machut (1937-2006) - nauczyciel, społecznik, organizator życia kulturalnego w Kościerzynie i powiecie oraz działacz Zrzeszenia Kaszubsko-Pomorskiego. Acta Cassubiana. T. 15: 2013 s. 400-407.

501. ŚLĘCZKA Ryszard: Krakowskie spotkanie Towarzystwa Historii Edukacji i seminarium naukowe poświęcone 10. rocznicy śmierci profesora Czesława Majorka. Przegląd HistorycznoOświatowy. R. 56: $2013 \mathrm{nr}$ 1/2 s. 218-223.

26 IX $2012 \mathrm{r}$

502. WAŁĘGA Agnieszka: Spotkanie z okazji 10 rocznicy śmierci Profesora Czesława Majorka. Biuletyn Historii Wychowania. [Nr] 29: 2013 s. 267-272.

Kraków, 26 IX 2012 r.

503. NIEWĘGŁOWSKA Genowefa: Myśl i działalność pedagogiczna matki Pauli Maleckiej [1852-1927]. [W:] Matka Paula Malecka i jej dzieło. Pierwsze Sympozjum w Zgromadzeniu Córek Najczystszego Serca Najświętszej Maryi Panny. Red. Teresa Jakoniuk. Nowe Miasto nad Pilicą-Drohiczyn 2013 s. 65-78.

504. MOSKWA Jacek: Antoni Marylski [1894-1973] i Laski. [Wyd. 2]. Warszawa 2013 Tow. „Więź” ss. 300, nlb. 3, tabl. 16, il. (Biblioteka „Więzi”; t. 282). 
Ośr. Wychowawczy im. Róży Czackiej w Laskach; Wyd. 1. Kraków 1987.

505. MARKIEWICZOWA Hanna: Pan profesor Stanisław Mauersberg [1924-2012] odszedł... Biuletyn Historii Wychowania. [Nr] 29: 2013 s. 147-148.

506. FRĄCZ Czesława: Wspomnienie o Leonii Mossoczy [1904-1990] - nauczycielce z Nowej Wsi. Kwartalnik Czudecki. R. 11: 2009 nr 4 s. 19.

507. BLASK świadectwa. Błogosławiona nauczycielka Natalia Tułasiewicz [1906-1945]. Aut. Barbara Judkowiak [i in.]. Wyd. 2, poszerz. Poznań 2013 Bonami Wydaw.-Drukarnia ss. 61, nlb. 2, il.

Z treści: Szablak Krystyna: Błogosławiona Natalia Tułasiewicz (1906-1945) s. 5-8; Judkowiak B.: „Przyjmij mnie na nowo do swej klasy” (nauczyciele „w szkole” błogosławionej Natalii) s. 11-44; Ilustracje s. 59-61; Wyd. 1. 2006.

508. DUDA Tadeusz: Ks. Jan Niedojadło (1893-1968). Rocznik Sądecki. T. 41: 2013 s. $405-407$.

509. ZWIERZYŃSKI Franciszek: Kombatantka i nauczycielka. Rzecz o Halinie Olczakowej z domu Jarockiej [ur. 1927]. Rocznik Mińskomazowiecki. T. 21: 2013 s. 213-220.

510. DUDEK Aleksandra: Jadwiga Omiljanowska [1922-2011] - wspomnienie. Rocznik Muzeum w Gliwicach. T. 24: 2013 s. 475-476, sum., Zsfg.

511. STAŃCZUK Janusz: Stanisław Piotrowski. Kapłan, harcerz, wychowawca. Pastoralne aspekty wychowania dzieci i młodzieży w pismach i działalności ks. Stanisława Piotrowskiego (1912-1998). Warszawa 2013 Wydaw. Sióstr Loretanek ss. 352, nlb. 1, tabl. 6, il., sum.

512. GÓRKA Magdalena: Moralne wychowanie w duchu polskości poza Polską - życie i działalność Aleksandry Podhoreckiej [ur. 1939]. Przegląd Polsko-Polonijny. Nr 5/6: 2013 s. 539-446, sum.

513. ZASŁUŻONY Wieruszowianin i Sandomierzanin. Nauczyciel-Wychowawca-Społecznik. Marian Poloński (14 VIII 1932 - 23 XII 2012). [Aut.] Damian Gil, Barbara Rosińska, Jadwiga Tomalkiewicz, Natalia Wróbel. Zeszyty Sandomierskie. R. 19: 2013 nr 35 s. 72-76.

514. BABIŃSKI Jarosław: Ks. Franciszek Sawicki [1877-1952] jako pedagog. Studia Koszalińsko-Kołobrzeskie. Nr 20: 2013 z. 1/2 s. 7-17, sum.

515. JASIŃSKI Janusz: Franciszek Schnarbach [1905-1947]. Nauczyciel szkół polskich. Kilka sprostowań i uzupełnień. Komunikaty Mazursko-Warmińskie. R. 55: 2011 z. 1 s. 91-96.

516. SHEYBAL-ROSTEK Aleksandra: Stanisław Sheybal (1891-1976), krzemieniecki nauczyciel, działacz kulturalny, malarz i fotograf. Dagerotyp. Nr 19: 2010 s. 61-76, sum.

517. MUSIELAK Michał: Heliodor Święcicki (1854-1923). Poznań 2013 Wydaw. Nauk. UAM ss. 275, nlb. 1, il., sum. (Biografie Rektorów Uniwersytetu im. Adama Mickiewicza w Poznaniu).

518. ANTONINA Tatar [1899-1959]. Człowiek - pedagog. Oprac. i red. Krystyna Zabrzewska, Barbara Jurak. Wyd. 2. Suche-Kraków 2013 Szkoła Podst.; Wydaw. Inst. Ks. Misjonarzy ss. 40, nlb. 8 , il.

Wyd. 1. 2003.

519. PRZYBYSZEWSKI Kazimierz: Władysława Tatarzanka (1893-1970), pedagog, dyrektorka Miejskiego Gimnazjum Żeńskiego w Toruniu. Rocznik Toruński. [T.] 40: 2013 s. $233-242$. 
520. BAJSAROWICZ Grażyna: Wspomnienie o Eugenii Wesołowskiej [1912-2011]. Rocznik Dzierżoniowski. T. 21: 2011 [dr.:] 2012 s. 227-228.

521. KULECKA Alicja, Schiller-Walicka Joanna: Dorota Zamojska (10 grudnia $1960-25$ grudnia 2013). Wspomnienie. Rozprawy z Dziejów Oświaty. T. 50: 2013 s. 11-23.

522. ZARÓWNA Barbara: Wspomnienie o Franciszku Zarównym [1929-2010]. Rocznik Dzierżoniowski. T. 20: 2010 [dr.:] 2011 s. 296-297.

523. MAŁACHOWSKI Ryszard: Działalność wychowawcza księdza Aleksandra Zienkiewicza [1910-1995] na Kresach Wschodnich Rzeczypospolitej i Dolnym Śląsku. Zielona Góra 2013 Oficyna Wydawnicza Uniw. Zielonogórskiego ss. 724, il.

524. CZARNIK Oskar Stanisław: Roman Żuliński [1839-1864] - nauczyciel w Radzyminie i Warszawie, dyrektor tajnej poczty powstańczej. [W:] Powstanie styczniowe. Uczestnicy, instytucje, wybrane zdarzenia. Obchody i pamiątki w powiecie wołomińskim. Kobyłka 2013 s. 71-92.

\section{DZIEJE OŚWIATY POZASZKOLNEJ}

\section{Oświata dorosłych}

525. BRUSIŁO Zygmunt: Pięć lat Uniwersytetu Trzeciego Wieku w Bolesławcu. Rocznik Bolestawiecki. T. 5: 2012 [dr.:] 2013 s. 62-65.

526. DZIAŁANIA Sudeckiego UTW na rzecz seniorów w Wałbrzychu w latach 2003-2013. Red. Tomasz Smejlis. Wałbrzych 2013 Sudecki Uniw. Trzeciego Wieku ss. 142, il.

Uniwersytet Trzeciego Wieku; zawiera też wspomnienia.

527. FABIŚ Artur, Łacina-Łanowski Artur: Uniwersytet Trzeciego Wieku w Oświęcimiu krótka monografia instytucji. [W:] Kreatywna starość. 15-lecie oświęcimskiego Uniwersytetu Trzeciego Wieku. Praca zbior. pod red. A. Fabisia, A. Łaciny-Łanowskiego, Łukasza Tomczyka. Oświęcim-Katowice 2013 s. 47-66.

Lata 1997-2012.

528. KROPLEWSKI Jarosław: Zagadnienia oświatowo-wychowawcze w regulaminach służby na okrętach. Biuletyn Historyczny. Nr 28: 2013 s. 86-110.

Od $1918 \mathrm{r}$.

529. SOCHA Jan: Z kochania się rodzi. Uniwersytety ludowe - przeszłość i teraźniejszość. Warszawa-Łomża 2013 Fund. Pol. Uniwersytetów Lud.; Tow. Uniwersytetów Lud.; Oficyna Wydawnicza „Stopka” ss. 311, nlb. 4, il. (Biblioteka Uniwersytetów Ludowych).

Od 1989 r.

530. WILKOWSKI Eugeniusz: Katolicka Wszechnica Ludowa w Chełmie (1993-1998) na tle dziejów uniwersytetów ludowych. Rocznik Chełmski. T. 17: 2013 s. 363-383. 


\section{Biblioteki}

531. DOMAŃSKA Katarzyna: Biblioteki szkolne jako centrum kultury w środowisku lokalnym na wybranych przykładach. [W:] Książka i prasa w kulturze. Red. Katarzyna Domańska, Bernadeta Iwańska-Cieślik. Bydgoszcz 2013 s. 320-330.

532. DRZEWIECKI Marcin: Biblioteki publiczne i szkolne w środowisku społecznym. Wybrane aspekty. [W:] Książka i prasa w kulturze. Red. Katarzyna Domańska, Bernadeta Iwańska-Cieślik. Bydgoszcz 2013 s. 309-319.

533. KACZMAREK Iwona: Biblioteki oświatowe i publiczne w Łodzi w dwudziestoleciu międzywojennym. Acta Universitatis Lodziensis. Folia Librorum. [Vol.] 17: 2013 s. 75-95, sum.

534. KOWKIEL Lilia: Dary dla bibliotek szkolnych na prowincji litewsko-białoruskiej w I połowie XIX wieku. Annales Universitatis Paedagogicae Cracoviensis. Folia 146: Studia ad Bibliothecarum Scientiam Pertinentia. [T.] 11: 2013 s. 144-150, abstr.

535. POMES Kinga: Biblioteki Towarzystwa Szkoły Ludowej w Babicy przed I wojną światową. Kwartalnik Czudecki. R. 7: 2005 nr 2 s. 17.

536. KLECZKOWSKA Janina: O pierwszej „Solidarności” w Liceum Ogólnokształcącym im. G. Piramowicza w Augustowie - wspomnienie. Rocznik Augustowsko-Suwalski. T. 13: 2013 s. $187-196$.

\section{DZIEJE RUCHU NAUCZYCIELSKIEGO}

\section{Opracowania ogólne}

537. SKOCZYLAS Jadwiga: Wiekowy Związek. Kwartalnik Czudecki. R. 7: 2005 nr 4 s. 8-9. Uzup.: 100 lat Związku Nauczycielstwa Polskiego. Tamże s. 7-8.

538. W 90. ROCZNICE powstania na ziemi rybnickiej ruchu społeczno-zawodowego nauczycieli. Wybór źródeł. [Wyd.] Mieczysław Kula. Rybnik 2013 Zw. Nauczycielstwa Pol. Oddz. ss. 235 , nlb. 2 , il.

\section{Pamiętniki nauczycieli}

539. BOCHENEK Leon: Wspomnienia. Warszawa-Gdańsk 2013 Galan ss. 515, il.

Nauczyciela żyjącego w 1. 1894-1973.

540. BOGOLUBOW Zoe (s. Jozafata CR): Pamiętnik nauczycielki. Warszawa-Szydłowiec 2013 Ikona ss. 54.

Zarazem zmartwychwstanki i autorki nowatorskich rozwiązań pedagogicznych żyjącej w 1. 1885-1955.

541. [BYSZEWSKI Antoni W.]: W służbie ludziom i Ojczyźnie. Pamiętnik Antoniego W. Byszewskiego (1876-1963). Życiorysem autora poprz. Michał Raczkowski; pod red. Mirosława Krajewskiego. Rypin 2013 Verbum ss. 64, il. 
542. DUDZIŃSKA-REIZER Franciszka: Szkoły mojego życia. Wspomnienia nauczycielki. Wstęp i oprac. nauk. Piotr Chmielowiec. Rzeszów 2013 IPN-KŚZpNP. Oddz. ss. 235, nlb. 1, tabl. 24, il. (Seria Wydawnicza IPN Oddział w Rzeszowie).

Pamiętnik aut. (1909-2008) z lat własnej nauki a następnie 44 lat pracy pedagogicznej w Iłży, Janowcu, Warszawie oraz na Wołyniu w okresie II RP, tajnego nauczania i powojennej działalności jako nauczycielki i wizytatorki.

543. DYŁO Józef: O Tuwimie, szkole i Inowłodziu. Wspomnienia wiejskiego nauczyciela. Zeszyty Wiejskie. Z. 16: 2011 s. 212-230.

Wspomnienia o działalności szkoły podstawowej w Inowłodziu w 1. 1948-1979 oraz o kontaktach poety z jej uczniami w 1. 1948-1953.

Uzup.: Dyło Andrzej: O moim Ojcu! Tamże s. 210-211.

544. FEITEK Alojzy: Wypoczynek w Rowach i nie tylko. Inowrocław 2013 Drukarnia Pozkal ss. 260 , il.

Wspomnienie autora (ur. 1937) o pracy w szkolnictwie we Wdzydzach, Starym Bukowcu i Starych Polaszkach w okresie PRL i III RP.

545. GOLLY Antoni: Wspomnienia śląskiego „srakotłuka”. Spömnitnio ślönskigo „srakoktłuka”. Zabrze 2013 Nar. Oficyna Śląska ss. 136.

Wspomnienia autora (ur. 1933) o pracy nauczyciela fizyki, gł. w szkołach wiejskich na Opolszczyźnie. il.

546. KASPERSKI Stanisław: Ślady życia i chwile zadumy. Lublin 2013 Polihymnia ss. 100,

Wspomnienia autora (ur. 1935) z wojennego i powojennego dzieciństwa w Majdanie-Grabinie, studiów prawniczych w Lublinie i polonistycznych w Krakowie, pierwszych lat pracy nauczyciela w Tarnówce, Szczecinku, Osinach i Kraśniku Farbycznym.

547. KUKUŁKA Alfred: Wspomnienia z rodzinnych stron. Mielec 2013 Nakł. aut. ss. 506, il. Rodzina nauczyciela z Wolicy Piaskowej, XX-XXI w.

548. NATALIA Tułasiewicz, bł.: Przeciw barbarzyństwu. Listy, dzienniki, wspomnienia. Oprac. Dorota Tułasiewicz i Barbara Judkowiak. Poznań 2013 Wydaw. Warszawskiej Prowincji Karmelitów Bosych ss. 267, nlb. 2, il.

Pamiętniki nauczycielki żyjącej w 1. 1906-1945.

549. NIEWIADOWSKA Swietłana: Notatnik nauczycielki. Kazachstan, 1994. [Cz. 2]. My, Sybiracy. Nr 24: 2013 s. 46-57.

Wspomnienia z nauczania języka polskiego i religii we wsi Biełojarka.

Cz. 1. Tamże. Nr 5: 1994.

550. OSĘKOWSKI Julian, pseud. Orla: EGO SUM. Portret. Rocznik Głogówecki. Nr 3: 2009 s. $332-334$.

Wspomnienia autora (ur. 1913) z rodzinnych Niebeszczan, nauki tamże i w Sanoku, Seminarium Nauczycielskiego w Krośnie, pracy pedagogicznej przed wojną, działalności w ZWZ oraz powojennych studiów pedagogicznych i kariery nauczycielskiej.

551. POŻOGA Józef: Kursy dla analfabetów. Zeszyty Wiejskie. Z. 13: 2008 s. 242-247.

Wspomnienia nauczyciela szkół w Cierżniach i Rozworach, 1. 1950-1952.

552. RAFALSKA Kazimiera: Przeżyłam łagry. Wspomnienia polskiej nauczycielki z Polesia. Kraków 2013 Wydaw. Serafin ss. 393, nlb. 2, il.

Wspomnienia autorki (1909-1998) z przedwojennej młodości i pracy nauczycielki we wsi Łyszcze na Polesiu, kontynuowania pracy w szkole po wkroczeniu sowietów, zesłania do obozów pracy w Mińsku, a następnie w Ugliczu nad Wołgą, powrotu do Polski w 1948 r. 
553. [RATAJCZYK Emanuel]: Moje życie w Głogówku. Z Emanuelem Ratajczykiem rozmawia Jarosław Kłuskiewicz. Portret. Rocznik Głogówecki. Nr 4: 2010 s. 377-385.

Wspomnienia z przyjazdu do miasta w 1945 r., pracy we młynie, nauki w liceum pedagogicznym i pracy w różnych szkołach średnich.

554. RULKA Janusz: Moje bydgoskie półwiecze. W liceum pedagogicznym 1959-1964. Kronika Bydgoska. T. 34: 2013 s. 553-592.

Wspomnienia nauczyciela.

555. SOLARZOWA Zofia: Życie spełnione. Mój pamiętnik. [Cz.] 1. Oprac. i red. nauk. Andrzej Sowa. Warszawa 2013 Stow. Promni [i in.] ss. 499, il. Stow. Promni, MHPRL.

Żyła 1902-1988 nauczyciele, pamiętniki.

556. WSPOMNIENIA przemyskich nauczycielek z okresu I wojny światowej. [Wyd.] Maciej Dalecki. Przemyskie Zapiski Historyczne. R. 18: 2010/2011 [dr.:] 2013 s. 143-169.

\section{ORGANIZACJE MLODZIEŻOWE}

\section{Harcerstwo}

557. ABY przypomnieć zapomniane. Red. Anna Fenby Taylor, Monika Serafin. Górki Wielkie 2013 Fund. im. Zofii Kossak ss. 155, il. Fund. im. Zofii Kossak.

Ośr. Harcerski w Górkach Wielkich, 1. 30. XX w.

558. BARTKOWIAK Przemysław: Bogdan Rusinek - założyciel oraz dowódca konspiracyjnej organizacji młodzieżowej „Harcerstwo Polskie” działającej na terenie Drezdenka w latach 1950-1951. Studia Zachodnie. [T.] 15: 2013 s. 67-79, sum.

559. BIEDRZYCKI Wojciech: Odtworzenie 3 Krakowskiej Drużyny Harcerzy im. Kazimierza Pułaskiego, Zielonej Trójki w 1956 roku. Kraków 2013 Komisja Hist. ZHP Chorągwi Krakowskiej ss. 181 , nlb. 1 , il.

Losy drużyny w XX w.; zawiera też wspomnienia i biografie.

560. CZOPOWICZ Stanisław: Niepokorni i niezależni. Korzenie harcerskiej niepodległości (1980-1989). Przyczynek metodologiczny i porządkujący. [W:] Warszawa niezłomna. Antysystemowe formy opozycji i oporu społecznego w stolicy (1980-1989). Pod red. Bartłomieja Noszczaka. Warszawa 2013 s. 139-170.

561. DĄBROWSKI Stanisław Jan: Harcerki z tamtych lat... Lublin 2013 Stow. Szarych Szeregów. Oddz. ss. 442, il.

W Lublinie, 1. 1939-1949.

562. DZIEJE harcerstwa płockiego 1912-2012. Studia i materiały. Pod red. Benedykta Sandomierskiego i Michała Kacprzaka. Płock 2013 Hufiec ZHP Płock im. Obrońców Płocka ss. 516, il.

563. GŁOWACKA-SOBIECH Edyta: Harcerstwo w Polsce w latach 1944-1990. Poznań 2013 Wydaw. Nauk. UAM ss. 379. UAM w Poznaniu. (Psychologia i Pedagogika; nr 196).

564. HARCERSTWO łomżyńskie wczoraj i dziś. T. 3. Praca zbiorowa. Red. Zbigniew Kamionowski, Dorota Górska. Łomża 2013 Komenda Hufca Nadnarwiańskiego ZHP; Stow. Przyj. 
Harcerstwa Łomżyńskiego ss. 578, tabl. 1. Komenda Hufca Nadnarwiańskiego ZHP im. Adama Chętnika, Stow. Przyj. Harcerstwa Łomżyńskiego.

Z treści: Dobroński Adam Czesław: Przedmowa. Patrząc okiem historyka s. 14-16; Kamionowski Z.: Harcerstwo w Polskiej Rzeczpospolitej Ludowej. Słowo wstępne s. 17-20; Kamionowski Z.: Harcerstwo od 1950 do 1975 r., tj. do nowego podziału administracyjnego kraju s. 21-32; Harcerskie wspomnienia s. 33-188; Kamionowski Z.: Związek Harcerstwa Polskiego od 1975 do 1991 r., tj. w okresie istnienia Chorągwi Łomżyńskiej (uzupełnienie dotychczas opublikowanych materiałów w tomie I i II) s. 189-194; Harcerskie wspomnienia s. 195-260; O swoim (ich) harcerstwie wspomnienia s. 261-296; Nieznane karty historii harcerstwa. Prace konkursowe s. 297-424; Biografie harcerskie s. 425-488; Hufiec Nadnarwiański ZHP im. Adama Chętnika w roku obchodów stulecia harcerstwa łomżyńskiego s. 489-572; Aneks do tomu I. Poczet komendantów łomżyńskich hufców harcerskich - wersja uzupełniona i poprawiona s. 573-578.

T. 1. 2008.

565. HARCERSTWO w Ozorkowie 1912-2012. Ludzie, wydarzenia, wspomnienia, dokumenty, fotografie. Wybór tekstów i ikonografii, oprac., red. Agnieszka Kazek; oprac. biogramów Halina Janczak; współpr. red. Anna Błaszczyk, H. Janczak. Ozorków-Łódź 2013 Marron Edition ss. 110 , il.

566. HARCERSTWO zakopiańskie w latach 1913-1945. Zakopane 2013 Stow. Muzeum Harcerskie im. Olgi i Andrzeja Małkowskiego ss. 326, il., sum.

Treść: Rokosz Mieczysław: Zakopiańskie początki polskiego skautingu s. 5-126; Dall Lesław: Harcerstwo zakopiańskie w latach 1918-1945 s. 127-308.

567. JANUSZEWSKA-JURKIEWICZ Joanna: Harcerze lwowscy na Górnym Śląsku po II wojnie światowej. [W:] Kresowianie na Górnym Śląsku. Pod red. Bogusława Tracza. KatowiceGliwice 2012 s. 231-256.

568. KAWSKI Tomasz: Działalność Żydowskich Organizacji Skautowych „Hanoar Haiwri” i „Hanoar Hacijoni” na ziemiach polskich w latach 1928-1939. [W:] Interpretatio rerum gestarum. Studia ofiarowane profesorowi Januszowi Ostoja-Zagórskiemu w 70. rocznicę urodzin. Red. Aleksander Jankowski, Jacek Maciejewski. Bydgoszcz 2013 s. 233-255.

569. KRET Urszula: Kronika Okręgu Małopolskiego Związku Harcerstwa Rzeczypospolitej. 2013 rok. Krakowski Rocznik Historii Harcerstwa. T. 9: 2013 s. 129-158.

570. KUKLA Wiesław, Miszczuk Marian: Wydawnictwa Związku Harcerstwa Polskiego na Wschodzie 1941-1947. Materiały i źródła. Warszawa 2013 Tomiko ss. 200.

Rec.: Karpiński Dariusz, Przeglad Polsko-Polonijny. Nr 5/6: 2013 s. 581-582.

571. LEONHARD Bolesław: Krakowska „Piętnastka” w latach 1931-1961. Krakowski Rocznik Historii Harcerstwa. T. 9: 2013 s. 51-63.

572. MAŁSZYCKI Dariusz: Formy działalności harcerstwa gdyńskiego w latach 1959-1989. Rocznik Gdyński. Nr 25: 2013 s. 126-139.

573. NOWAK-KULCZYŃSKI Konrad: Krąg Starszych Harcerzy Seniorów im. księcia Józefa Poniatowskiego w Śmiglu w XX-lecie powstania. Śmigiel 2013 Urząd Miej. Śmigla ss. 128, il.

Po 1989 r.

574. ODRODZENIE harcerstwa po Październiku ,56 roku. Dokumenty. [Wyd.] Julian Kwiek. Krakowski Rocznik Historii Harcerstwa. T. 9: 2013 s. 85-102.

575. POTOK Roman, Jankowska Karina: 100 lat kościańskiego harcerstwa. Zarys dziejów 1912-2012. Kościan 2013 Przeds. Wydawniczo-Usługowe „Tęcza” ss. 200, tabl. 16, il. 
576. ROGOŻ Michał: Wydawnictwo Harcerskie „Horyzonty” (1958-1976). Annales Universitatis Paedagogicae Cracoviensis. Folia 146: Studia ad Bibliothecarum Scientiam Pertinentia. [T.] 11: 2013 s. 197-211, abstr.

577. ROMANOWSKI Stefan: „Był taki Hufiec”. Hufiec Związku Harcerstwa Polskiego Warszawa Saska Kępa 1957-1961. Warszawa 2013 Chorągiew Stołeczna ZHP. Hufiec Warszawa Praga Południe. Instruktorski Krąg Pokoleń „Romanosy” ss. 52, il.

578. STEFANIAK Ryszard: Powstanie i rozwój skautingu w Częstochowie do 1914 roku. Częstochowskie Teki Historyczne. T. 3: 2012 s. 153-171.

579. TROPEM naszej drużyny. Z kroniki i wspomnień harcerzy Białej 3. Zabrzańskiej Drużyny. Zbiór, red., indeks Leonard Denkowski. Katowice 2010 [B. w.] ss. 418, il.

Lata $1945-1950$.

580. W STULECIE krakowskiego harcerstwa. Materiały sesji naukowej odbytej 9 kwietnia 2011 roku. Red. t. Marta Bochenek. Kraków 2012 Tow. Miłośn. Historii i Zabytków Krakowa; Muzeum Hist. M. Krakowa ss. 193, nlb. 3, tabl. 8, il. (Kraków w Dziejach Narodu; 31).

Treść: Rokosz Mieczysław: Słowo wstępne s. 5-8; Hausner Wojciech: Narodziny krakowskich drużyn skautowych i ich udział w bojach o niepodległość 1910-1920 s. 9-41; Wojtycza Janusz: Harcerstwo krakowskie w latach 1920-1939 s. 43-57; Miłobędzki Paweł: Krakowskie Szare Szeregi 1939-1945 s. 59-88; Rzońca Bartosz: Krakowska Choragiew Harcerzy w latach 1945-1952 s. 89-101; Rokosz M.: Odrodzenie harcerstwa w Krakowie po Październiku 1956 roku s. 103-128; Wojtycza Krzysztof: Krakowskie „niepokorne” hufce w rzeczywistości PRL-u s. 129-160; Kapusta Marcin: Druga odnowa harcerstwa - Kręgi Instruktorów Harcerskich im. A. Małkowskiego i Ruch Harcerski s. 161-172; Sibila Leszek L.: Kolekcja harcerska w zbiorach Muzeum Historycznego Miasta Krakowa s. 173-180; Bukowski Jerzy, Żugaj Andrzej, Wilk Zbigniew, Kapusta M.: Dyskusja s. 181-191.

581. WAŁEK Bernard: Wychowanie do wiary w skautingu i harcerstwie. Krakowski Rocznik Historii Harcerstwa. T. 9: 2013 s. 103-128.

582. WYCHOWAWCZA rola harcerstwa. 100 lat harcerstwa w Wielkopolsce. Pod red. Macieja Zenona Maślińskiego. Poznań-Ostrów Wielkopolski 2013 „Alpa” Creative Solutions ss. 81, il. ZHP. Komenda Chorągwi Wielkopolskiej im. Powstańców Wielkopolskich 1918-19.

583. Z DZIEJÓW harcerstwa w Mińsku Mazowieckim. [Z. 1]. Red. zespół Miron Krajewski, Stanisław Fijałkowski, Zbigniew Tokarski. Mińsk Mazowiecki 2009 Komenda Hufca ZHP Mazowsze ss. 66, il.

Toż. Z. 2. Red. zespół M. Krajewski, Izabela Sagnowska. Mińsk Mazowiecki 2010 ss. 85, il.

Toż. Z. 3, cz. 1: Monografia 14. Drużyny Harcerskiej Spadłych Listków do Szyby Przyklejonych Deszczu Kropelką. Red. Bożena Caban-Drzewińska. Ptaki 2010 [B.w.] ss. 106, il.

Toż. Z. 4: Harcerstwo w Cegłowie. Red. zespół Z. Tokarski, M. Krajewski. Mińsk

Mazowiecki 2012 Komenda Hufca ZHP Mazowsze ss. 102, il.

Toż. Z. 5. [Aut.] Stanisław Czajka. Mińsk Mazowiecki 2013 ss. 74, il.

584. Z DZIEJÓW rybnickiego harcerstwa. Red. Elżbieta Soroczan, Zbigniew Soroczan. Katowice 2013 Śląsk ss. 285, il.

Treść: Hm. Józef Pukowiec [1904-1942]. Bohater Hufca Ziemi Rybnickiej. Oprac. E. Soroczan s. 9-18 Rybnickie hufce ZHP w latach 1920-1949. Oprac. E. Soroczan, Z. Soroczan s. 19-98; Szkolenie harcerskiej kadry instruktorskiej w Rybniku (lata 1920-1990). Oprac. Maria Wilgus s. 99-116; Harcmistrzynie i harcmistrzowie Hufca Ziemi Rybnickiej z lat 1920-2012. Oprac. E. Soroczan, Z. Soroczan s. 117-182; Podharcmistrzynie i podharcmistrzowie Hufca Ziemi Rybnickiej z lat 1920-2012. Słownik biograficzny. Oprac. E. Soroczan, Z. Soroczan s. 183-242; Wykaz przewodników i organizatorów Hufca Ziemi Rybnickiej z lat 1920-2012 s. 243-270; Rybnicki Krąg Instruktora Seniora. Oprac. Józefa Hanak s. 271-278; Materiały 
źródłowe s. 279-283; Errata do rozdziału „Władze Hufca w latach 1945-1991” w publikacji „Harcerstwo na ziemi rybnickiej w latach 1945-1990”. Oprac. E. Soroczan, Z. Soroczan s. 284-285.

\section{Inne}

585. ANUSZ Andrzej, Perzyna Łukasz: NZS na ATK (1980-1989) na tle historii opozycji studenckiej. Warszawa-Łódź 2013 Wydaw. Pol. IHOO; Inst. Hist. NN im. Andrzeja Ostaja Owsianego ss. 471, il.

ATK - Akademia Teologii Katolickiej w Warszawie (obecnie Uniwersytet Kardynała Stefana Wyszyńskiego).

586. BADURA Anna: ”...zniszczyć wszystko, co jest czerwone". Młodzieżowe organizacje antykomunistyczne na Górnym Śląsku i Podbeskidziu w latach 1945-1954. CzasyPismo. 2012 nr 1 s. $102-111$.

587. CHCIELIŚMY być sobą. Ruch Młodzieży Niezależnej we wspomnieniach uczestników (1983-1989). Pod red. Marka Rusakiewicza i Dariusza A. Rymara; przy współpr. Zbigniewa Bodnara. Gorzów Wlkp. 2013 Fund. Zach. Ośr. Badań Społ. i Ekonom. ss. 432, il. + 2 dyski optyczne (DVD).

588. DWORACZEK Kamil: Kontakty Niezależnego Zrzeszenia Studentów z zagranicznymi organizacjami studenckimi w latach 1980-1981. [W:] Świat wobec „Solidarności” 1980-1989. Red. Paweł Jaworski, Łukasz Kamiński. Warszawa 2013 s. 479-493.

589. DŹWIGAŁ Magdalena: Niepodległościowe organizacje młodzieżowe działające na terenie powiatu chojeńskiego w latach 1945-1956. Rocznik Chojeński. T. 5: 2013 s. 183-222, Zsfg.

590. GRZEGORCZUK Dariusz: 75. rocznica Ogólnopolskiej Konferencji IdeowoProgramowej Związku Młodzieży Wiejskiej Rzeczypospolitej Polskiej „Wici” w Chodowie (2-11 lipca 1937 roku). Szkice Podlaskie. Z. 19/20: 2011/2012 [dr.:] 2013 s. 365-381.

591. HAUSNER Wojciech, Kapusta Marcin: Bierny opór krakowskiego środowiska instruktorów harcerskich ZHP i jego rozbicie przez Urząd Bezpieczeństwa w latach 1949-1950. Krakowski Rocznik Historii Harcerstwa. T. 9: 2013 s. 5-22.

592. KONEFAŁ Jan: Próba utworzenia ZMP w Prywatnym Męskim Gimnazjum i Liceum Biskupim w Lublinie. [W:] Abiit, non obiit. Księga poświęcona pamięci księdza profesora Antoniego Kościa SVD. Red. Antoni Dębiński [i in.]. Lublin 2013 s. 929-942.

593. KRÓL Joanna: Związek Młodzieży Polskiej w strukturach średnich szkół ogólnokształcących w Polsce w latach 1948-1957. Dzieje Najnowsze. R. 45: 2013 [nr] 3 s. 63-80, sum.

594. KRZYSZTOFEK Katarzyna: Sodalicja Mariańska Akademików w Krakowie w latach 1891-1953. Czasopismo Prawno-Historyczne. T. 65: 2013 z. 1 s. 423-441.

595. KUCHARSKI Władysław S.: Stowarzyszenia polskiej młodzieży w Styrii. Niemcy Austria-Szwajcaria. T. 2: 2007 s. 73-98.

Lata $1878-1914$.

596. MŁODY Hufiec 1945-1946. Poznań 2013 Gotów ss. 219, il. Katol. Stow. Młodzieży Archidiec. Poznańskiej. grafie.

Okólniki Katolickiego Stowarzyszenia Młodzieży Męskiej w Poznaniu, wspomnienia członków oraz foto- 
597. PLESKOT Patryk: Konspiracyjne Niezależne Zrzeszenie Studentów na Uniwersytecie Warszawskim (1982-1989). [W:] Warszawa niezłomna. Antysystemowe formy opozycji i oporu społecznego w stolicy (1980-1989). Pod red. Bartłomieja Noszczaka. Warszawa 2013 s. 171-182.

598. SADOWSKA Joanna: Z dziejów ZMW na Białostocczyźnie. [W:] Społeczeństwo, wojsko, polityka. Studia i szkice ofiarowane profesorowi Adamowi Czesławowi Dobrońskiemu z okazji 70. urodzin. Red. nauk. Małgorzata Dajnowicz, Adam Miodowski, Tomasz Wesołowski. Białystok 2013 s. 527-544.

599. SIKORSKI Tomasz: Chrześcijańscy i narodowi. „Kolumna Młodych” - autonomiczny dodatek prasowy Chrześcijańskiego Związku Młodzieży „Odnowa” (marzec-lipiec 1946 rok). [W:] Prasa Narodowej Demokracji. T. 4: Prasa lokalna, regionalna, środowiskowa. Red. nauk. Ewa Maj, Aneta Dawidowicz. Lublin 2013 s. 317-335.

600. SZCZYPKA Andrzej: Represje wobec członków młodzieżowych organizacji niepodległościowych w województwie śląskim/katowickim i krakowskim w latach 1945-1956 (wybrane aspekty). Prace Historyczne. [T.] 140: 2013 z. 3 s. 279-297, abstr.

601. SZCZYPKA Andrzej: Sylwetka Włodzimierza Kapczyńskiego na tle młodzieżowej organizacji niepodległościowej „Związek Walki z Komunizmem” w Sosnowcu (1948 roku) i ruchu NSZZ „Solidarność”. Almanach Historyczny. T. 15: 2013 s. 89-115, sum.

602. WIERZBICKI Marek: Ostatni bunt. Młodzieżowa opozycja polityczna u schyłku PRL, 1980-1990. Fakty, konteksty, interpretacje. Warszawa-Lublin 2013 IPN-KŚZpNP ss. 352. IPN-KŚZpNP. Oddz. w Lublinie, ISP PAN.

603. ZIELIŃSKI Mateusz: Zarys historii Rady Uczelnianej Zrzeszenia Studentów Polskich przy UMK w Toruniu 1950-1989. Rocznik Toruński. [T.] 39: 2012 s. 75-98, sum., Zsfg.

604. ŻEBRAK Anna: Instytucjonalizacja politycznych ugrupowań młodzieżowych w Polsce po 1989 roku. Toruń 2013 Adam Marszałek ss. 356, nlb. 1, il.

Anna Gruca

Instytut Historii PAN 